\title{
Criação de vídeo digital no ensino-aprendizagem de Probabilidade
}

Thiago Picos de Morais

\author{
DISSERTAÇÃO APRESENTADA \\ AO \\ INSTITUTO DE MATEMÁTICA E ESTATÍSTICA \\ DA \\ UNIVERSIDADE DE SÃO PAULO \\ PARA \\ OBTENÇÃO DO TÍTULO DE MESTRE
}

Programa: Mestrado Profissional no Ensino de Matemática

Orientador: Prof. Dr. Marcos Nascimento Magalhães

São Paulo, outubro de 2011 


\section{Criação de vídeo digital no ensino-aprendizagem de Probabilidade}

Esta é a versão original da dissertação elaborada pelo candidado Thiago Picos de Morais, tal como submetida à Comissão Julgadora 


\section{Resumo}

Morais, T. P. Criação de vídeo digital no ensino-aprendizagem de Probabilidade. 2019. Dissertação (Mestrado) - Instituto de Matemática e Estatística. Universidade de São Paulo, 2019.

Tendo como pressuposto que o ensino-aprendizagem de Matemática no Ensino Fundamental pode se utilizar das novas tecnologias, foi proposta, neste trabalho, a investigação das possíveis contribuições da criação de vídeos digitais como recurso didático para o desenvolvimento de conceitos relativos à probabilidade nos anos finais do Ensino Fundamental. Ao longo do trabalho, procurou-se traçar um panorama do atual cenário do ensino-aprendizagem de probabilidade. Para isso, foi realizado um levantamento sobre sua presença nos documentos oficiais, além de uma busca na literatura a respeito das principais dificuldades encontradas e de diferentes abordagens contendo possibilidades variadas de intepretações para seu significado. São apresentadas também algumas ideias referentes ao uso de metodologias ativas no contexto escolar, que buscam fornecer ao estudante um lugar de protagonismo em sala de aula, e aspectos a respeito do uso de vídeo como potente recurso de ensino. Por fim, com base na análise de uma primeira experiência realizada em outubro de 2017 , foi descrita e analisada uma proposta de trabalho realizada com alunos de nono ano de Ensino Fundamental visando o desenvolvimento de conceitos relacionados à probabilidade utilizando o vídeo como criação coletiva.

Palavras-chave: Vídeo; produção de vídeos; probabilidade; educação básica; educação estatística. 


\section{Sumário}

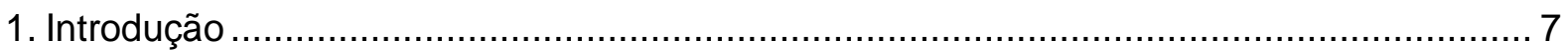

1.1. Objetivos e questão de pesquisa …............................................................. 7

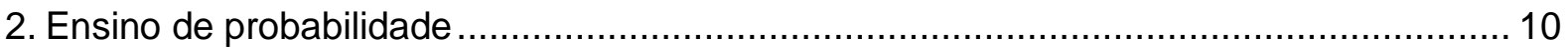

2.1. A probabilidade no currículo: documentos oficiais ........................................... 11

2.2. Principais dificuldades encontradas no ensino-aprendizagem ............................. 13

2.3. Diferentes abordagens para o ensino de probabilidade...................................... 15

3. Educação: uso de tecnologias e novas práticas ...................................................... 23

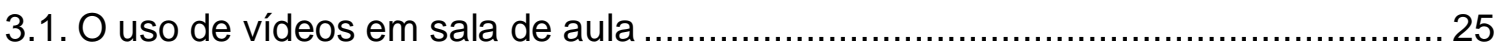

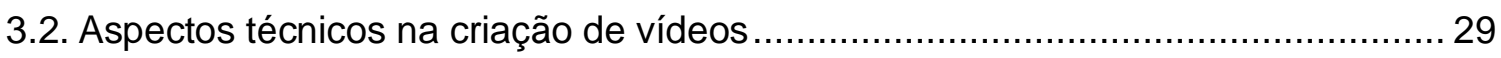

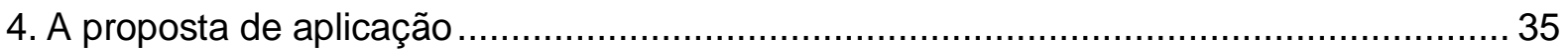

4.1. Uma primeira experiência do uso do vídeo em sala de aula................................ 35

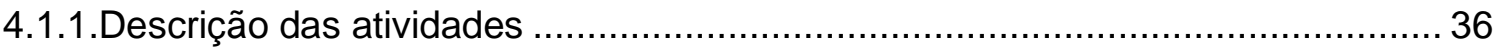

4.1.2.Do projeto-piloto ao projeto final: contribuições e mudanças.............................. 38

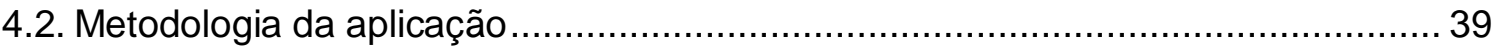

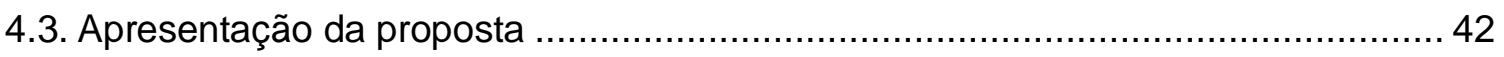

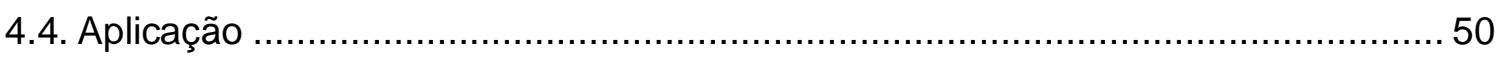

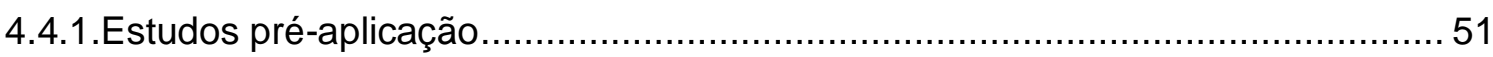

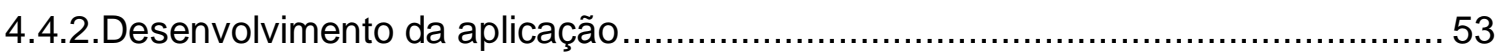

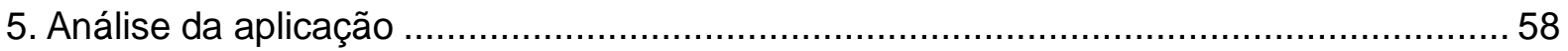

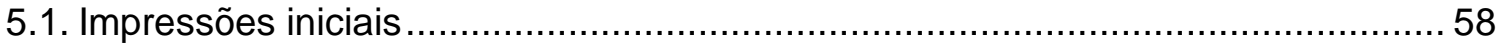

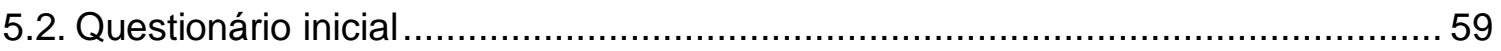

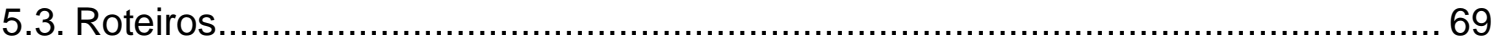

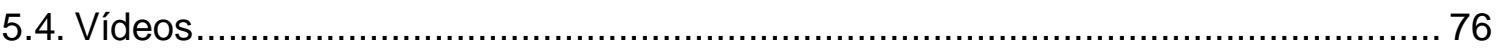

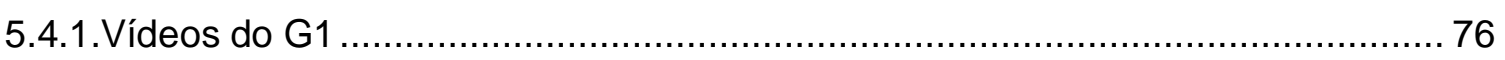

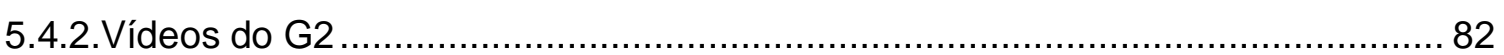

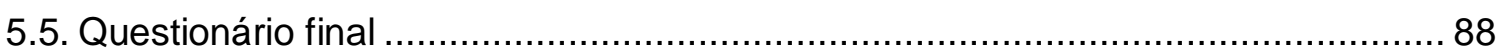

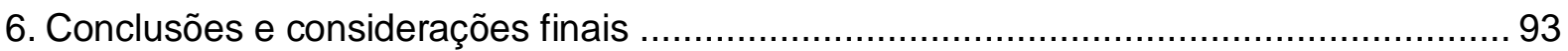

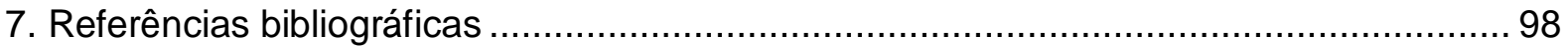

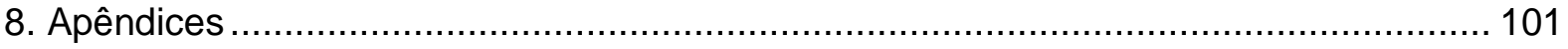




\section{Lista de Figuras}

Figura 1 - Imagem retirada de Magalhães e Lima (2013) .......................................... 20

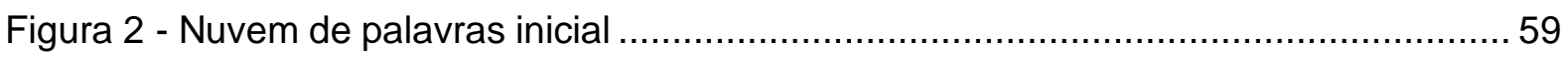

Figura 3 - Gráfico de desempenho da primeira questão do Questionário inicial .................61 61

Figura 4 - Gráfico de desempenho da terceira questão do Questionário inicial ................... 62

Figura 5 - Gráfico de desempenho na Questão 5 do Questionário inicial ............................. 65

Figura 6 - Gráfico de desempenho na Questão 6 do Questionário inicial ............................. 66

Figura 7 - Gráfico de desempenho na Questão 7 do Questionário inicial .............................. 66

Figura 8 - Gráfico de desempenho na Questão 8 do Questionário inicial ............................ 67

Figura 9 - Gráfico que apresenta nível de motivação dos estudantes. ............................... 68

Figura 10 - Gráfico que apresenta nível de familiaridade com questões técnicas ............... 69

Figura 11 - Slide da apresentação realizada na terceira aula ........................................... 70

Figura 12 - Slide da apresentação realizada na terceira aula .......................................... 71

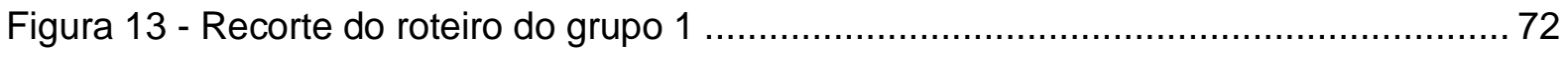

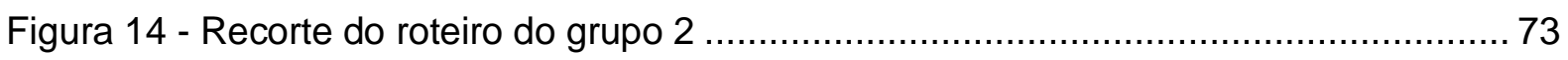

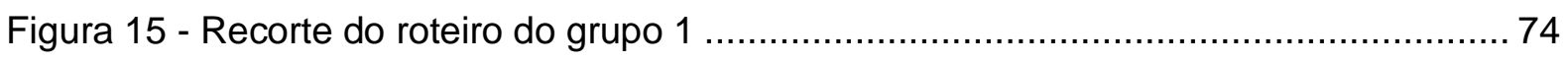

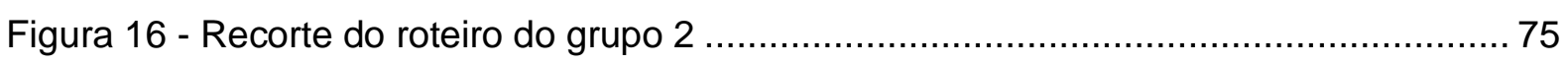

Figura 17 - Observações de aluno sobre vídeo do G1 ................................................ 79

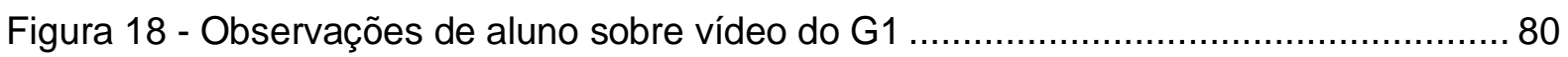

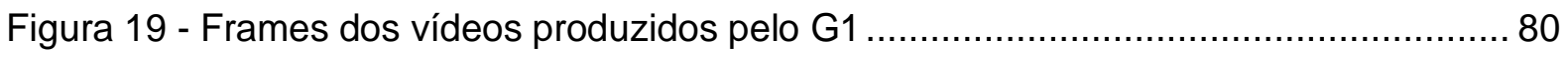

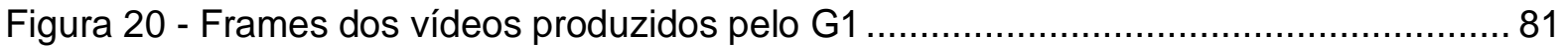

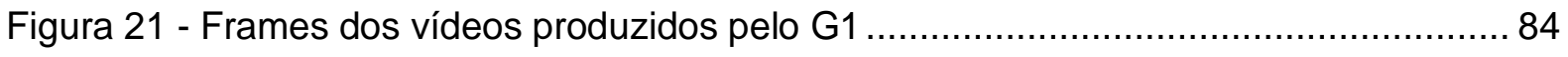

Figura 22 - Observações de aluno sobre vídeo do G1 ................................................. 84

Figura 23 - Observações de aluno sobre vídeo do G1 ................................................ 85

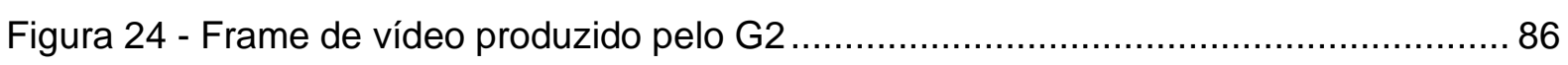

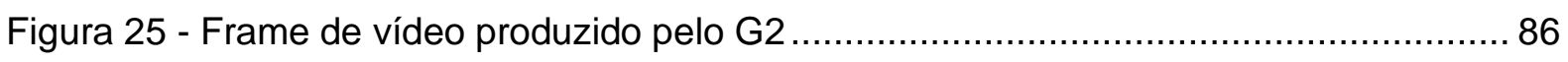

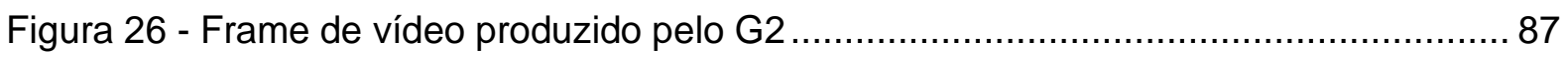

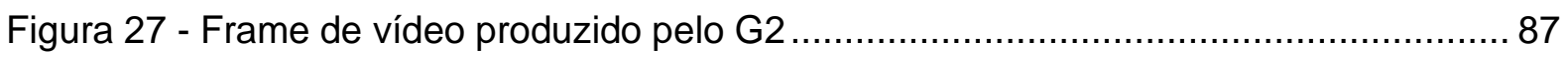

Figura 28 - Gráfico que apresenta dados coletados no Questionário final........................... 92

Figura 29 - Gráfico que apresenta dados coletados no Questionário final.......................... 92

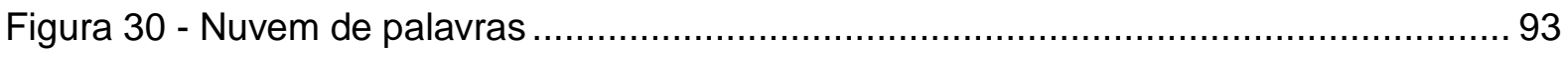

Figura 31 - Captura da tela principal do programa de edição OpenShot .......................... 101 


\section{Índice de Quadros}

Quadro 1 - Habilidades da BNCC relacionadas ao ensino de probabilidade ...................... 11

Quadro 2 - Relação de elementos de significado presentes na concepção intuitiva ............ 16

Quadro 3 - Relação de elementos de significado presentes na concepção laplaciana........ 17

Quadro 4 - Relação de elementos de significado presentes na concepção frequencial ...... 19

Quadro 5 - Relação de elementos de significado presentes na concepção subjetiva .......... 19

Quadro 6 - Relação de elementos de significado presentes na concepção matemática ..... 21

Quadro 7 - Aspectos relevantes na hora das filmagens ................................................ 32

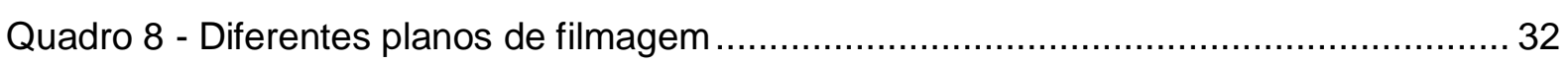

Quadro 10- Comparação do cronograma com a efetiva duração do projeto ........................ 37

Quadro 11 - Distribuição das aulas do projeto.......................................................... 43

Quadro 12 - Descrição detalhada das aulas do projeto ................................................ 46

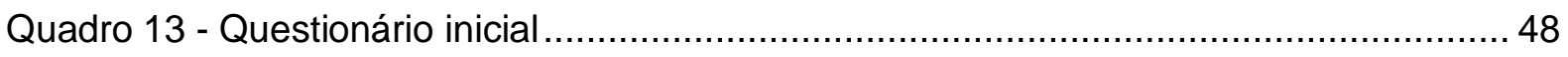

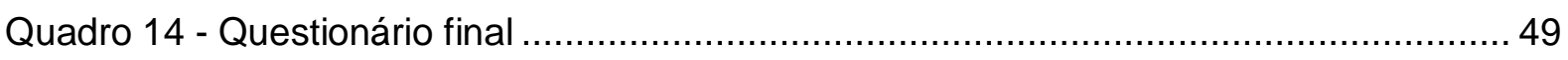

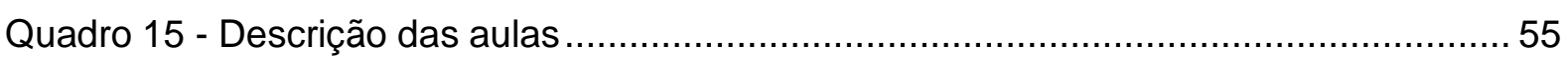

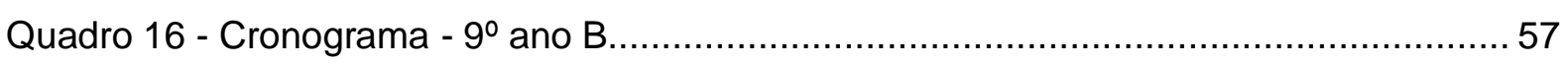

Quadro 17 - Respostas de alunos na primeira questão do Questionário inicial ................... 60

Quadro 18 - Respostas de alunos na terceira questão do Questionário inicial .................... 63

Quadro 19 - Respostas de alunos na quarta questão do Questionário inicial ...................... 64

Quadro 20 - Transcrição de recorte de discussão coletiva na apresentação do G1 ........... 77

Quadro 21 - Transcrição de recorte de discussão coletiva na apresentação do G1 ............78

Quadro 22 - Transcrição de recorte de discussão coletiva na apresentação do G2 ............ 82

Quadro 23 - Transcrição de recorte de discussão coletiva na apresentação do G2 ............ 83

Quadro 24 - Análise comparativa dos questionários ..................................................... 89

Quadro 25 - Análise comparativa dos questionários .................................................... 90

Quadro 26 - Análise comparativa dos questionários .................................................. 90

Quadro 27 - Análise comparativa dos questionários ................................................. 91 


\section{Introdução}

O ensino-aprendizagem de Matemática no Ensino Fundamental e, mais especificamente, a introdução de conceitos relacionados à probabilidade podem se utilizar das novas tecnologias que, a cada dia, aparecem com mais força no cotidiano dos alunos e na escola.

Estamos atualmente diante da crescente necessidade de apropriação e integração da tecnologia ao currículo e às práticas pedagógicas que aparece em documentos oficiais, como a Base Nacional Comum Curricular (Brasil, 2016). Ao mesmo tempo, vemos um ensino de probabilidade no contexto escolar sendo trabalhado de forma tradicional, sendo a mudança de postura do professor para a posição de mediador na construção do conhecimento e de aluno para sujeito protagonista, um grande desafio para os docentes da área. No cotidiano da sala de aula, professores buscam (re)elaborar formatos, pensando em estratégias e buscando recursos que tornem o processo de aprendizagem mais ativo. (BACICH E MORAN, 2018)

Tendo essas ideias como pressupostos, propõe-se, neste trabalho, abordar o processo da criação de vídeos digitais como recurso didático para o ensino de Probabilidade no segundo ciclo do Ensino Fundamental.

\subsection{Objetivos e questão de pesquisa}

O principal objetivo da pesquisa é a elaboração e a execução de uma abordagem para o ensino-aprendizagem de Estatística utilizando recursos tecnológicos que potencializem e amplifiquem essa aprendizagem e que concedam um lugar de protagonismo para o estudante. Para isso, pretende-se desenvolver um projeto para a introdução do conceito de probabilidade nos anos finais do Ensino Fundamental, utilizando o vídeo como recurso.

Os objetivos gerais de pesquisa são: investigar como a produção de um vídeo pode ser um recurso didático com potencial para o ensino e elaborar estratégias para facilitar e potencializar a introdução ao conceito de probabilidade em sala de aula.

Dessa forma, os objetivos específicos são: 
- traçar um panorama a respeito do atual cenário do ensino de probabilidade, com foco nas dificuldades no ensino-aprendizagem;

- identificar características do processo de criação audiovisual e compreender as contribuições para a aprendizagem;

- conceber, desenvolver, experimentar e analisar situações de ensino utilizando o vídeo para introduzir o conceito de probabilidade.

Buscando alcançar os objetivos propostos, constitui-se a seguinte pergunta norteadora deste estudo: Quais são as contribuições do processo de criação de vídeos digitais no ensino-aprendizagem do conceito de probabilidade nos anos finais do Ensino Fundamental?

Mais especificamente, pretende-se, ao longo da pesquisa, elaborar uma proposta de experimento que utilize uma das possibilidades de uso do vídeo em sala de aula apresentadas por Moran (1995): o vídeo como produção.

O texto da Base Comum Curricular Nacional (Brasil, 2016) traz algumas competências gerais, dentre elas, algumas merecem destaque por estarem de acordo com o que se propõe aqui.

1. Valorizar e utilizar os conhecimentos historicamente construídos sobre 0 mundo físico, social, cultural e digital para entender e explicar a realidade, continuar aprendendo e colaborar para a construção de uma sociedade justa, democrática e inclusiva.

(...)

4. Utilizar diferentes linguagens - verbal (oral ou visual-motora, como Libras, e escrita), corporal, visual, sonora e digital -, bem como conhecimentos das linguagens artística, matemática e científica, para se expressar e partilhar informações, experiências, ideias e sentimentos em diferente

5. Compreender, utilizar e criar tecnologias digitais de informação e comunicação de forma crítica, significativa, reflexiva e ética nas diversas práticas sociais (incluindo as escolares) para se comunicar, acessar e disseminar informações, produzir conhecimentos, resolver problemas e exercer protagonismo e autoria na vida pessoal e coletiva.

Ao propor que os alunos produzam um vídeo sobre probabilidade, a primeira competência apresentada no documento é trabalhada a partir do momento em que 
eles deverão recorrer aos conhecimentos já existentes dessa área para explicar a realidade e continuar aprendendo.

A competência de número 4 está relacionada com a presente pesquisa, pois a produção do vídeo exige dos alunos a utilização de diferentes linguagens (verbal e não-verbal) e conhecimento da linguagem matemática. A quinta competência, por sua vez, também será desenvolvida uma vez que os alunos usarão tecnologias digitais para comunicar suas ideias e conhecimentos. A inclusão e apropriação de metodologias e atividades que incorporem o uso de tecnologias na sala de aula parecem, nesse sentido, uma demanda real no atual contexto da educação nacional.

No início da pesquisa será apresentada uma discussão e reflexão sobre ensino-aprendizagem de probabilidade e, novas práticas da educação - uso de tecnologias na sala de aula - que embasa a proposta elaborada pelo pesquisador. Em um segundo momento, haverá uma breve apresentação de primeira experiência do uso do vídeo em sala de aula e a proposta elaborada pelo professor com descrição detalhadas das atividades realizadas. Ao final da dissertação serão apresentadas a análise da proposta realizada e as conclusões e considerações finais. 


\section{Ensino de probabilidade}

O conteúdo escolhido para a aplicação do projeto é o ensino-aprendizagem do conceito de probabilidade para alunos dos anos finais do Ensino Fundamental. Assim sendo, caracteriza-se como objetivo de estudo o aprofundamento de ideias e concepções relacionadas ao conteúdo em questão. Para isso, neste capítulo será desenvolvida uma investigação acerca do atual cenário do ensino de probabilidade, com foco nas dificuldades apresentadas pelos alunos. Além disso, serão apresentados os conceitos e abordagens escolhidos para serem desenvolvidos com os estudantes ao longo da proposta de trabalho que será descrita nos Capítulos $4 \mathrm{e}$ 5.

Atualmente, vemos que os alunos de Ensino Fundamental, de forma geral, já possuem contato com experimentos de caráter aleatório em seu cotidiano. $O$ fenômeno aleatório, é definido por Magalhães e Lima (2013) como situação ou acontecimento cujos resultados não podem ser previstos com certeza. Não se trata, portanto, de uma realidade distante e pouco vivenciada pelos estudantes. Ao se pensar na introdução de conceitos probabilísticos, deve-se considerar essa vivência e levar os alunos a observar e analisar os componentes de imprevisibilidade intrínsecos a essas situações, pois segundo os autores, a probabilidade pode ser encarada como a teoria matemática utilizada para o estudo da incerteza oriunda de fenômenos desse caráter.

Corroborando com os autores, Lopes (2008) aponta que há a necessidade de compreensão, por parte dos alunos, dos conceitos relacionados à incerteza e aleatoriedade. Segundo a autora, se configura como um objetivo do ensino de Matemática no ciclo básico a percepção de que probabilidade é uma medida de incerteza. A autora ainda aponta que, além de permitir uma sólida base para o futuro desenvolvimento de estudos em áreas científicas, o conhecimento em probabilidade é imprescindível em um mundo em rápida e constante transformação, pois desenvolve capacidade de fazer previsões e favorece boas decisões.

Assim, temos que o estudo de estatística e probabilidade no Ensino Fundamental tem como objetivos "o desenvolvimento da capacidade de crítica e a autonomia desse aluno para que exerça plenamente sua cidadania, ampliando suas 
possibilidades de êxito na vida pessoal e profissional" e o "desenvolvimento de habilidades essenciais como a análise crítica e a argumentação" (LOPES 2008 p. 60).

\subsection{A probabilidade no currículo: documentos oficiais}

Os documentos oficiais nacionais de educação apontam para a importância do ensino de probabilidade. Olhando para o documento oficial elaborado mais recentemente, a Base Nacional Comum Curricular (Brasil, 2016), vemos a importância do desenvolvimento de algumas habilidades relacionadas ao ensino de probabilidade nos anos finais do Ensino Fundamental que constituem-se como essenciais para formação do estudante atual. O quadro abaixo apresenta a relação divulgada no documento.

Quadro 1 - Habilidades da BNCC relacionadas ao ensino de probabilidade

\begin{tabular}{|l|l|}
\hline $6^{\circ}$ ano & $\begin{array}{l}\text { Calcular a probabilidade de um evento aleatório, expressando-a por número } \\
\text { racional (forma fracionária, decimal e percentual) e comparar esse número com a } \\
\text { probabilidade obtida por meio de experimentos sucessivos. }\end{array}$ \\
\hline $7^{\circ}$ ano & $\begin{array}{l}\text { Planejar e realizar experimentos aleatórios ou simulações que envolvem cálculo } \\
\text { de probabilidades ou estimativas por meio de frequência de ocorrências. }\end{array}$ \\
\hline $8^{\circ}$ ano & $\begin{array}{l}\text { Calcular a probabilidade de eventos, com base na construção do espaço amostral, } \\
\text { utilizando o princípio multiplicativo, e reconhecer que a soma das probabilidades } \\
\text { de todos os elementos do espaço amostral é igual a 1. }\end{array}$ \\
\hline $9^{\circ}$ ano & $\begin{array}{l}\text { Reconhecer, em experimentos aleatórios, eventos independentes e dependentes } \\
\text { e calcular a probabilidade de sua ocorrência, nos dois casos. }\end{array}$ \\
\hline
\end{tabular}

Outro documento que pode ser analisado são os Parâmetros Curriculares Nacionais, que apresenta como um dos objetivos para o ensino de Matemática no Ensino Fundamental "identificar características de acontecimentos previsíveis ou aleatórios a partir de situações-problema, utilizando recursos estatísticos e probabilísticos". (BRASIL. MEC, 1997, p. 56). Dessa forma, o documento aponta para a necessidade de possibilitar que o aluno saiba tratar as informações que recebe, 
reconhecer situações que envolvam o conceito de aleatoriedade, lidar com dados estatísticos e raciocinar com base nas ideias de probabilidade e combinatória.

Mais especificamente em relação à probabilidade há a indicação de que:

\begin{abstract}
A principal finalidade é a de que o aluno compreenda que grande parte dos acontecimentos do cotidiano são de natureza aleatória e é possível identificar prováveis resultados desses acontecimentos. As noções de acaso e incerteza, que se manifestam intuitivamente, podem ser exploradas na escola, em situações nas quais o aluno realiza experimentos e observa eventos (em espaços equiprováveis). (p 36).
\end{abstract}

O documento analisado ainda aponta que há uma demanda social que indica a necessidade de abordar elementos de estatística, probabilidade e combinatória já no Ensino Fundamental II (p. 21). Para tanto, o documento lista, como conteúdos conceituais e procedimentais, a exploração da ideia de probabilidade em situaçõesproblema simples, identificando sucessos possíveis, sucessos seguros e as situações de "sorte" e a utilização de informações dadas para avaliar probabilidades (p. 61).

Podemos olhar também para a forma como outro documento oficial elaborado para a rede estadual aborda o ensino de probabilidade. Na proposta de Currículo do Estado de São Paulo da área de Matemática e suas tecnologias para o ciclo II do Ensino Fundamental e para o Ensino Médio (2012), pode-se observar que pouco se fala sobre o ensino de probabilidade. Certamente, a probabilidade aparece no quadro de descrição dos conteúdos, mas no texto de apresentação dos conteúdos, o tema é apenas mencionado como parte integrante de um dos blocos temáticos da matemática: o bloco das relações (p. 44).

No quadro de conteúdos apresentado neste documento, vemos um foco maior do ensino de probabilidade no Ensino Médio. No entanto, as primeiras noções de probabilidade aparecem no $3^{\circ}$ bimestre do $7^{\circ}$ ano, momento no qual o aluno deverá "saber resolver problemas simples envolvendo a ideia de probabilidade (porcentagem que representa possibilidades de ocorrência)". Depois disso, o tema aparece somente no $9^{\circ}$ ano, série na qual se propõe a resolução de problemas de contagem e a introdução à probabilidade. Nesse momento, pretende-se desenvolver no aluno a habilidade de "saber resolver problemas que envolvam ideias simples sobre probabilidade." 
Essa proposta do Estado de São Paulo não caminha no mesmo sentido de algumas ideias apresentadas nos PCN, que trazem a demanda de se abordar elementos da estatística, da combinatória e da probabilidade desde os ciclos iniciais tendo em vista que "estar alfabetizado, neste final de século, supõe saber ler e interpretar dados apresentados de maneira organizada e construir representações, para formular e resolver problemas que impliquem o recolhimento de dados e a análise de informações" (p.84).

Ao analisar a listagem de conteúdos propostas nos documentos oficiais, é possível notar que se faz necessário certificar-se que os alunos investiguem, vivenciem e posteriormente sistematizem conceitos relacionados aos eventos aleatórios e a noção de experimento.

\subsection{Principais dificuldades encontradas no ensino-aprendizagem}

Com a finalidade de traçar um panorama geral a respeito do atual cenário do ensino de probabilidade, um dos objetivos específicos propostos no início do trabalho, pretende-se aqui investigar na literatura quais são as principais dificuldades encontradas em relação à área de probabilidade nos anos finais do Ensino Fundamental.

Há na literatura algumas produções científicas que se propõem a investigar diferentes abordagens para a introdução de conceitos relacionados à probabilidade e indicar dificuldades encontradas ao longo de todo o processo de ensinoaprendizagem deste tema. Oliveira e Cordani (2016) destacam dificuldades mais acentuadas no ensino de probabilidade do que nos demais tópicos do currículo de Matemática do ensino básico. Tal característica, segundo os autores, é fruto de pouca familiaridade e reflexão dos professores com questões envolvendo a incerteza e a variabilidade devido à tardia inclusão da disciplina nos cursos de licenciatura em Matemática. Coutinho e Santos (2019) mencionam a necessidade da efetiva reflexão sobre conceitos estatísticos na formação dos docentes, que "devem ser letrados estatisticamente, sob risco de trabalharem tais conteúdos de forma automática e pouco crítica" (p.2).

Corroborando com os autores, Lopes (2008) afirma que: 
A formação dos professores, atualmente, não incorpora um trabalho sistemático sobre estocástica, dificultando a possibilidade desses profissionais desenvolverem um trabalho significativo com essa temática nas salas de aula da educação básica. (p.70)

Segundo a autora, a má formação de professores que ensinam em Educação Infantil, Ensino Fundamental e Médio é "um dos principais impedimentos ao ensino efetivo de probabilidade e estatística na educação básica" (p.70).

Outra dificuldade de ensino está indicada pelas abordagens instrumentais dos livros didáticos atuais, pois, assim como foi possível observar na análise do item anterior, é nítido um grande número de questões que apresentam uma preocupação apenas no correto manuseio de fórmulas para obter um cálculo correto, sem levantar nenhuma discussão a respeito do significado dos conceitos abordados. Constitui-se assim um ensino de probabilidade pautado em uma visão determinística que contrasta com o que indica Lopes (2008):

\footnotetext{
Uma vez mais ressaltamos que o ensino da estocástica deve propiciar ao estudante situações que Ihe permitam a superação do determinismo em favor da aleatoriedade. É necessário trabalharmos dentro do currículo de Matemática com situações que envolvam as ideias de acaso e de aleatório, pois, do contrário, estaremos reduzindo o ensino desta ao verdadeiro e falso de suas proposições. (p. 63)
}

Os aspectos supracitados relacionados às abordagens tradicionais dos livros didáticos, segundo Oliveira e Cordani (2016), "impedem uma discussão mais ampla de análise de dados e da importância da probabilidade nas análises estatísticas" ( $p$. 1266).

Batanero et al. (1994) também apresenta razões para algumas das dificuldades no ensino-aprendizagem de probabilidade. A correlação de conceitos estatísticos como a probabilidade com o raciocínio proporcional é enunciada como uma dessas razões, pelo fato desse raciocínio ser um conceito difícil em Matemática. Além disso, a existência de falsas intuições que os alunos trazem para a sala de aula e a exposição dos conceitos de uma forma altamente abstrata e formal colaboram para a propagação das dificuldades dos estudantes em questões referentes a esse assunto.

Tais dificuldades de ensino relatadas acima, contribuem para que os 
estudantes não compreendam com clareza e não reconheçam a presença do aleatório em algumas situações cotidianas. Isso é facilmente observado nas falhas sistemáticas dos alunos durante as resoluções de problemas.

\subsection{Diferentes abordagens para o ensino de probabilidade}

Embora os documentos oficiais apontem para a necessidade de se trabalhar a probabilidade, podemos perceber que não abordam a forma como esse tema deve ser trabalhado. Sendo assim, o docente atual poderá equivocadamente sentir-se preparado para planejar aulas desse tema, sem ter clareza da importância de ter grande cautela na abordagem desses conceitos. Há de se desenvolver habilidades essenciais e propor desdobramentos conceituais aos alunos, mas o método utilizado para aproximação ao objeto de estudo configura-se como um constante desafio para o professor.

Visando qualificar o embasamento teórico que subsidiará a reflexão e elaboração das abordagens que serão utilizadas na proposta e, posteriormente sua análise, serão abordados neste capítulo algumas das principais interpretações e definições para o significado de probabilidade apresentadas por Batanero (2005). Como indica a autora, essas devem ser levadas em conta para o ensino do tema, pois ao longo de suas trajetórias escolares, os estudantes necessitam construí-las e relacioná-las de maneira progressiva.

\footnotetext{
É necessário um "trânsito flexível" entre diferentes significados parciais, que são alcançados após um processo de estudo prolongado; esse processo deve ser planejado e distribuído entre diferentes níveis educacionais. Batanero, 2005, p.257, tradução nossa.
}

Para cada uma das intepretações apresentadas, a autora explora cinco componentes, denominados por ela como elementos de significado. São eles: (1) 0 campo de problemas no qual o objeto emerge, (2) os elementos linguísticos relacionados ao significado, (3) os procedimentos e algoritmos presentes no contexto, (4) as definições e propriedades dos objetos e suas relações com demais objetos matemáticos e (5) os argumentos e demonstrações dessas propriedades. Segundo Batanero (2005), esses elementos possuem como finalidade a análise de uma 
situação, tarefa matemática ou processo de aprendizagem que utilize o significado em questão.

A primeira interpretação apresentada pela autora é relacionada ao significado intuitivo da probabilidade. Tal interpretação contempla o campo das intuições e ideias iniciais a respeito do tema. Já apresentadas neste trabalho como uma das dificuldades presentes no processo de ensino-aprendizagem de probabilidade, as falsas intuições que os alunos trazem para a sala de aula, fazem parte das concepções prévias dos estudantes e agem como os primeiros construtores do conceito. Sendo assim, devem ser explorados e refletivos constantemente. Algumas ideias intuitivas, como frases e expressões coloquiais para quantificar probabilidade de ocorrência de eventos ou expressar grau de confiança em situações de natureza aleatória despontam até mesmo em pessoas que não se aprofundaram ou nem iniciaram estudos efetivos em probabilidade. Segundo a autora, o desenvolvimento e reflexão dessas ideias são importantes para o progresso na sistematização do conceito de probabilidade. Abaixo pode-se observar um quadro que apresenta os elementos de significado pertencentes à interpretação intuitiva da probabilidade.

Quadro 2 - Relação de elementos de significado presentes na concepção intuitiva

\begin{tabular}{|l|l|}
\hline Campos de problemas & Sorteios, adivinhações. \\
\hline Algoritmos e procedimentos & Manipulação de geradores aleatórios, dados, cartas. \\
\hline Elementos linguísticos & Linguagem ordinária. \\
\hline Definições e propriedades & Opinião, imprevisível, crença. \\
\hline Conceitos relacionados & Sorte, azar, destino. \\
\hline
\end{tabular}

As principais definições e interpretações para o significado de probabilidade que serão desenvolvidas e investigadas ao longo da proposta de aplicação são denominadas por Batanero (2005) como a intepretação Laplaciana (clássica) e a frequentista. A primeira, a definição de significado Laplaciana é a clássica definição de que a probabilidade é a atribuição de um valor na forma de razão entre número de casos favoráveis e número de casos possíveis. Nela é essencial que seja levado em consideração que há a necessidade de reduzir os acontecimentos em um certo 
número de casos equiprováveis, isto com probabilidade igualmente possível entre eles. A autora ainda destaca que:

Tal definição se encontrou inadequada inclusive na época de Laplace, já que além de ser circular e restritiva, não ofereceu resposta à pergunta do que é realmente a probabilidade; apenas proporcionou um método prático de cálculo de probabilidade de alguns sucessos simples. Por outro lado, não pode ser aplicada a experimentos com um número infinito de possibilidades. (p. 254, tradução nossa).

Costumeiramente apresentada em sala de aula, tal definição pode ser observada no excerto do livro didático dos autores Imenes e Lellis (2010) destinado aos alunos dos anos finais do Ensino Fundamental:

A probabilidade (ou chance) é um número entre 0 e 1 (ou entre $0 \%$ e 100\%) que informa quanto a ocorrência de um determinado fato é provável. Se a probabilidade é zero (ou 0\%), o evento nunca ocorrerá (por exemplo: obter 7 pontos no lançamento de um dado comum); se a probabilidade é 1 (ou $100 \%$ ), o evento sempre ocorrerá (por exemplo: obter menos de 7 pontos no lançamento de um dado comum). Se conhecemos todas as possibilidades de resultados em certa situação e sabemos que as chances de ocorrência desses resultados são iguais, podemos obter a probabilidade (ou chance) de um determinado resultado calculando a razão entre o número de possibilidades desse resultado e o número total de possibilidades naquela situação (p. 288).

Nota-se a restrição de utilização dessa interpretação na indicação dos autores sa necessidade de conhecimento de todas as possibilidades de resultados e que a ocorrência de algum deles não pode ser mais provável que de outro.

Abaixo há a relação dos elementos de significados presentes na interpretação clássica apontada por Batanero (2005).

Quadro 3 - Relação de elementos de significado presentes na concepção laplaciana

\begin{tabular}{|l|l|}
\hline Campos de problemas & Cálculo de sucesso e risco em jogos de azar. \\
\hline Algoritmos e procedimentos & $\begin{array}{l}\text { Combinatória, proporção, análise a priori da estrutura do } \\
\text { experimento. }\end{array}$ \\
\hline
\end{tabular}




\begin{tabular}{|l|l|}
\hline Elementos linguísticos & Listagem de possibilidades, fórmulas combinatórias. \\
\hline Definições e propriedades & $\begin{array}{l}\text { Razão entre casos favoráveis e possíveis, } \\
\text { equiprobabilidade de possibilidades. }\end{array}$ \\
\hline Conceitos relacionados & Esperança, equiprobabilidade, independência. \\
\hline
\end{tabular}

Além da clássica, outra interpretação que pretende-se desenvolver e investigar ao longo do projeto é denominada pela autora como a interpretação frequencial do significado de probabilidade. Segundo a autora, o significado frequencial surge com a demonstração da primeira Lei dos Grandes Números, de Bernoulli, no início do século XVIII. Tal concepção baseia-se na ideia de que há a possibilidade de atribuição de valores aos sucessos de natureza aleatória a partir de frequência relativa observada em uma grande série de ensaios do experimento. Referente a isso, Batanero (2005) destaca que:

Um problema prático é que no enfoque frequencial nunca obteremos o valor exato da probabilidade, apenas uma estimação. Por outro lado, às vezes é impossível realizar os experimentos exatamente nas mesmas condições e também é difícil saber com certeza qual é o número de experimentos que devemos realizar para aceitar a estimação da probabilidade como boa. (p.254, tradução nossa).

A interpretação frequencial apresentada acima, pode ser observada em Wild e Seber (2004) intitulada como "probabilidades a partir dos dados". Os autores destacam duas relações importantes com os modelos obtidos pela interpretação clássica.

Primeiro, se o modelo for razoável, então para todo experimento que possa ser repetido várias vezes seguidas, a probabilidade de um evento obtida a partir do modelo nos dirá a frequência relativa com qual o evento irá ocorrer a longo prazo. Segundo, podemos escolher não utilizar as frequências relativas observadas como nossas probabilidades, mas simplesmente utilizálas para nos sentirmos melhor com nossas probabilidades, obtidas a partir do modelo. Por exemplo, suponha que observássemos 24 caras em 40 lançamentos de uma determinada moeda. Poucas pessoas usariam 24/40 como probabilidade de dar cara para essa moeda. A maioria diria que $24 \mathrm{em}$ 40 é um resultado que concorda razoavelmente com o valor $1 / 2$ baseado no 
modelo e, assim, se sentiria mais à vontade ao utilizar esse valor em situações futuras (p.91).

O quadro abaixo apresenta dos elementos de significado apresentados por Batanero (2005) para a interpretação frequentista.

Quadro 4 - Relação de elementos de significado presentes na concepção frequencial

\begin{tabular}{|l|l|}
\hline Campos de problemas & Estimação de parâmetros em populações. \\
\hline Algoritmos e procedimentos & $\begin{array}{l}\text { Registro de dados estatísticos a posteriori, ajuste de } \\
\text { curvas, análise matemática, simulações. }\end{array}$ \\
\hline Elementos linguísticos & $\begin{array}{l}\text { Tabelas e gráficos estatísticos, curvas de densidade, } \\
\text { tabelas de números aleatórios, tabelas de distribuição. }\end{array}$ \\
\hline Definições e propriedades & $\begin{array}{l}\text { Limite das frequências relativas, caráter objetivo } \\
\text { baseado em evidência empírica. }\end{array}$ \\
\hline Conceitos relacionados & $\begin{array}{l}\text { Frequência relativa, universo, variável aleatória, } \\
\text { distribuição da probabilidade. }\end{array}$ \\
\hline
\end{tabular}

Além das definições apresentadas acima, Batanero (2005) apresenta ainda a interpretação subjetiva e a interpretação matemática para o significado de probabilidade. O significado subjetivo da probabilidade está relacionado ao grau de crença pessoal baseado no conhecimento de na experiência de cada indivíduo. Assim, a probabilidade ocorrência de algum evento fica condicionada a esse sistema de conhecimentos e pode ser não ser a mesma para diferentes pessoas. Nesse enfoque subjetivo, a repetição do experimento nas mesmas condições já não é necessária para dar sentido à probabilidade.

Quadro 5 - Relação de elementos de significado presentes na concepção subjetiva

\begin{tabular}{|l|l|}
\hline Campos de problemas & $\begin{array}{l}\text { Melhora do conhecimento sobre sucesso incertos, } \\
\text { incluindo os não repetitivos. }\end{array}$ \\
\hline Algoritmos e procedimentos & $\begin{array}{l}\text { Teorema de Bayes e atribuição subjetiva de } \\
\text { probabilidade. }\end{array}$ \\
\hline Elementos linguísticos & Expressões da probabilidade condicional. \\
\hline
\end{tabular}




\begin{tabular}{|l|l|}
\hline Definições e propriedades & $\begin{array}{l}\text { Caráter subjetivo, possibilidade de revisão por conta da } \\
\text { experiência. }\end{array}$ \\
\hline Conceitos relacionados & $\begin{array}{l}\text { Probabilidade condicional, distribuições a priori e } \\
\text { posteriori. }\end{array}$ \\
\hline
\end{tabular}

A interpretação matemática, por sua vez, caracteriza-se como uma visão mais abstrata e formal da probabilidade. Segundo a autora, ao longo do século $X X$, diversos autores se dedicaram a contribuir com uma teoria matemática formalizada sobre a probabilidade. Alguns a relacionam com tipo especial de medidas, enquanto outros se destinaram a sistematizá-la utilizando teoria dos conjuntos. Com todas as contribuições nessa direção, a probabilidade se define como um modelo matemático passível de ser utilizado para descrição e interpretação da realidade dos fenômenos aleatórios.

Segundo Magalhães (2006), a diferença entre a interpretação matemática apresentada e as definições clássica e frequentista é que as últimas "têm o apelo da intuição e permanecem sendo usadas para resolver inúmeros problemas" (p.11). No entanto, é apontado pelo autor que ambas não são suficientes para uma formulação mais rigorosa. A interpretação matemática carrega consigo o conjunto de axiomas de Kolmogorov para definir probabilidade, que foram retirados de Magalhães e Lima (2013) e estão apresentados na figura abaixo.

Figura 1 - Imagem retirada de Magalhães e Lima (2013)

\section{Definição 2.1: Probabilidade}

Uma função $P(\cdot)$ é denominada probabilidade se satisfaz as condições:

i) $0 \leq P(A) \leq 1, \forall A \subset \Omega$;

ii) $P(\Omega)=1$;

iii) $P\left(\bigcup_{j=1}^{n} A_{j}\right)=\sum_{j=1}^{n} P\left(A_{j}\right)$, com os $A_{j^{\prime} \mathrm{s}}$ disjuntos.

O quadro abaixo apresenta os elementos de significado indicados por Batanero (2005) referentes à definição clássica de probabilidade. 
Quadro 6 - Relação de elementos de significado presentes na concepção matemática

\begin{tabular}{|l|l|}
\hline Campos de problemas & $\begin{array}{l}\text { Quantificar a incerteza de resultados em experimentos } \\
\text { aleatórios abstratos }\end{array}$ \\
\hline Algoritmos e procedimentos & $\begin{array}{l}\text { Teoria dos conjuntos, álgebra dos conjuntos e teoria das } \\
\text { medidas. }\end{array}$ \\
\hline Elementos linguísticos & Símbolos da Teoria dos conjuntos. \\
\hline Definições e propriedades & Função mensuráveis \\
\hline Conceitos relacionados & $\begin{array}{l}\text { Espaço amostral, espaço de probabilidade e conjuntos } \\
\text { de Borel. }\end{array}$ \\
\hline
\end{tabular}

A partir da perspectiva de Batanero (2005), atribuindo ao conceito de probabilidade diversos significados e relacionando-os aos seus elementos de significado, é possível perceber que há a necessidade de se refletir em como devese aproximar o aluno dos conceitos relacionados ao ensino de probabilidade. Ao pensar na abordagem que a escola básica deve apresentar, podemos apontar para a necessidade de se explorar o significado intuitivo que o aluno traz consigo para a sala de aula e considerar duas concepções distintas do pensamento probabilístico: o significado clássico (ou laplaciano) e o significado frequentista.

Alternar a abordagem ao longo da proposta de trabalho constitui-se como uma estratégia para ampliar o repertório dos estudantes para além da exatidão das respostas relacionadas às atividades tradicionais realizadas pelos alunos nas salas de aula dos cursos de Matemática. Como aponta Lopes (2008):

O ensino da matemática tem como tradição a exatidão, o determinismo e o cálculo, opondo-se à exploração de situações que envolvam aproximação, aleatoriedade e estimação, as quais podem limitar a visão matemática que o aluno poderá desenvolver, dificultando suas possibilidades de estabelecimento de estratégias para a resolução de problemas diversificados que lhe surgirão ao longo de sua vida (p.63).

Segundo a autora, esse estabelecimento de metas e estratégias visando a resolução de problemas surge a partir de uma prática sustentada por problematizações que certamente favorecerá a realização de seus trabalhos futuros em diferentes ramos da atividade humana. 
A partir destas perspectivas apontada pelos autores, é possível perceber que o ensino de probabilidade deve ir além do foco que se dá às fórmulas e trabalhar principalmente com a ideia da incerteza. 


\section{Educação: uso de tecnologias e novas práticas}

Falar sobre as tecnologias na educação não é algo tão recente. Em 1970, a UNESCO abordou o uso de tecnologia em uma conferência sobre programas de formação para técnicos do ensino e a denominação "novas tecnologias da informação e da comunicação" surgiu na década de 80 (PONS, 1998). No entanto, ainda vemos, nas escolas, muitos professores com dificuldade de trazer recursos tecnológicos para sua prática docente. Tal dificuldade é justificada ora pela falta de capacitação do uso da tecnologia, ora pela limitação de suportes e recursos na instituição de ensino.

O mundo onde vivemos é híbrido e, portanto, "é absurdo educar de costas para um mundo conectado" (Moran, 2018, p.11). As Tecnologias de Informação e Comunicação (TIC) vêm se tornando, de forma crescente, importantes instrumentos de nossa cultura, e sua utilização, um meio concreto de inclusão e interação no mundo (LÉVY, 1999).

Sendo assim, observa-se crescente o número de publicações e estudos sobre a tecnologia na educação. Além disso, escolas e documentos oficiais estão buscando e incentivando a inclusão de práticas inovadoras com uso de tecnologia.

Santos (2003) destaca que a sociedade vem adquirindo novas maneiras de pensar e de conviver no mundo digital, exigindo do cidadão outros modos de agir e interagir em sociedade. Corroborando com essa ideia, Borba, Scucuglia e Ganadis (2014) afirmam que a tecnologia está mudando a noção do que é ser humano, uma vez que as tecnologias digitais móveis estão modificando nossos valores e a nossa forma de agir. Há um descompasso entre as mudanças que ocorrem dentro e fora da escola, formando um abismo entre esses dois tipos de prática. Vemos, portanto, um aluno totalmente familiarizado com smartphones, ferramentas de busca, aplicativos e demais aparatos tecnológicos que certamente tem outras necessidades e outra forma de se relacionar com aprendizagem do que o aluno que existia há algumas décadas. Esse mesmo aluno, no entanto, encontra na escola um lugar onde essa tecnologia não se faz tão presente como em sua vida cotidiana, o que afasta a escola ainda mais da realidade do estudante.

Neste sentido, vemos constantemente presente a ideia de que as tecnologias podem e devem entrar na prática docente de uma maneira cada vez mais intensa, pois "propiciam a reconfiguração da prática pedagógica, a abertura e plasticidade do 
currículo e o exercício de coautoria de professores e alunos" (Almeida; Valente, 2012, p.60 apud Moran 2018). Portanto, falar sobre a inclusão de tecnologias na sala de aula, implica também uma mudança de perspectiva ao se falar na forma como o aluno aprende e como esse aprendizado pode ser mais significativo. Segundo Moran (2018), em um mundo marcado pela aceleração e pela transitoriedade das informações, o centro de atenção passa a ser o aluno. Devemos, portanto, nesse contexto, refletir e ressignificar o papel do professor e o processo de aprendizagem.

Temos, tradicionalmente, a prática de uma metodologia dedutiva, na qual o professor transmite primeiro a teoria para, posteriormente, o aluno aplicá-la em situações mais específicas. (MORAN, 2018). Nesse sentido, há a visão de um docente bem preparado, capaz de expor a teoria de maneira clara e organizada e, logo após, ser competente o suficiente para selecionar uma sequência de exercícios que coloquem o aluno em uma situação de treino com uma escala progressiva de dificuldade.

Essa figura do professor, até hoje tão presente, não está contextualizada em um cenário que vem se apresentando nas últimas décadas com o avanço e a inclusão das novas tecnologias em sala de aula. Para além disso, não se encaixa mais ao modo de vida e à forma como as pessoas vêm lidando com o conhecimento. Aulas expositivas, com metodologia dedutiva e uma visão unilateral na qual o aluno recebe o que o professor ensina são práticas que pouco conversam com a multiplicidade de possibilidades que temos com o uso de novas tecnologias e com as ideias trazidas a respeito de metodologias ativas de aprendizagem (BACICH e MORAN, 2018).

Conforme evidenciam os autores, aprendemos de forma ativa desde que nascemos, a partir de situações concretas, que aos poucos ampliamos e generalizamos. Sendo assim, as aprendizagens por questionamento e experimentação, ou seja, uma aprendizagem mais ativa, são mais relevantes para uma compreensão mais ampla e profunda. Tomaremos então o conceito de metodologias ativas que:

dão ênfase ao papel protagonista do aluno, ao seu envolvimento direto, participativo e reflexivo em todas as etapas do processo, experimentando, desenhando, criando, com orientação do professor." (Bacich e Moran, 2018, p.4). 
Neste sentido, buscar estratégias de ensino nas quais o aluno participa efetivamente faz muito mais sentido diante do atual contexto em que vivemos. Além disso, vemos a importância também de unir essas novas práticas mais ativas com a mediação tecnológica na busca de uma aprendizagem que se apresenta mais flexível, interessante e significativa.

\subsection{O uso de vídeos em sala de aula}

Certamente o vídeo não se trata de uma tecnologia inventada exclusivamente para fins educacionais. No entanto, vem sendo incorporado gradativamente no processo de ensino-aprendizagem dentro e fora de sala. (ALMEIDA et al, 2014). Alguns autores como Ferrés $(1988,1996)$ e Moran $(1993,1995)$ já abordavam, no final da década de 80 e início da década de 90 , metodologias para a utilização do vídeo no ambiente escolar.

O vídeo como recurso didático já foi abordado como objeto de estudo em pesquisas na área de Educação. Moran (1995) discute o uso do vídeo em sala de aula, apontando que essa prática "aproxima a sala de aula do cotidiano, das linguagens de aprendizagem e comunicação da sociedade urbana, mas também introduz novas questões no processo educacional" (MORAN, 1995, p. 1).

O autor define que o vídeo é:

sensorial, visual, linguagem falada, linguagem musical e escrita. Linguagens que interagem superpostas, interligadas, somadas, não separadas. Daí a sua força. Nos atingem por todos os sentidos e de todas as maneiras. O vídeo nos seduz, informa, entretém, projeta em outras realidades (no imaginário) em outros tempos e espaços. (Moran 1993. p.2)

Segundo Moran (1995), o vídeo desperta a curiosidade e gera motivação para novos temas. Além disso, o autor aborda três importantes tópicos na produção dos vídeos pelos alunos: a documentação, que pressupõe registro de eventos, de aulas, de estudos do meio, de experiências, de entrevistas, de depoimentos; a intervenção, que promove a modificação de um dado programa ou material áudio visual, acrescentando novos dados e interpretações; e a expressão, que é voltada à forma 
de comunicação adaptada à sensibilidade das crianças e jovens. Esse último, tem uma dimensão moderna e lúdica, pois é de interesse dos estudantes o trabalho com criação de vídeos e a escola pode aproveitar esse interesse e, assim, propor atividades envolvendo esse recurso.

Outro autor que aparece como precursor da pesquisa com vídeos na educação é Ferrés $(1988,1996)$ que, no final dos anos 80 já apontava para a utilização enquanto recurso pedagógico e indicava possibilidades de utilização do vídeo em sala de aula. Segundo o autor, a tecnologia do vídeo, quando posta à disposição do aluno, provoca uma ação libertadora, pois os permite a experiência da pesquisa, de se avaliar e de se conhecer. Além disso, permite a rica experiência de uma criação coletiva (FERRÉS, 1996).

Ao pensar em sua utilização no processo de ensino-aprendizagem, há de se atentar para o seu uso em sala de aula. Sua utilização deve ir além da transmissão de imagens. Nesse sentido, "vale a pena pesquisar novos caminhos de integração do humano e do tecnológico; do sensorial, emocional, racional e do ético; do presencial e do virtual; de integração da escola, do trabalho e da vida." (MORAN, 2005, p. 3).

Borba, Scucuglia e Ganadis (2014) no livro "Fases das tecnologias digitais em Educação Matemática", traçam um panorama histórico do uso das tecnologias para o ensino da Matemática. Para isso, buscam entender como as inovações tecnológicas têm permeado o ensino, como elas foram se transformando, que tipo de atividades são realizadas e quais recursos foram utilizados. Sendo assim, os autores delimitam quatro fases e as descrevem detalhadamente, sendo a primeira delas iniciada na década de 1980 e a última referente ao uso das tecnologias atualmente.

De acordo com os autores, o vídeo como recurso didático surge na segunda fase, com início na primeira metade dos anos 90, e oferece diversos atrativos ao professor, pois compila diversos modos de comunicação integrados ao uso de diferentes tecnologias. Segundo os autores os vídeos "podem ser concebidos enquanto narrativas ou textos multimodais, compilam diversos modos de comunicação como oralidade, escrita, imagens dinâmicas, espaços, formas de gestualidade e movimentos".

No entanto, com o advento da internet rápida estamos atualmente na quarta fase do uso de tecnologias na educação matemática (BORBA et al, 2014, p. 35) e o vídeo tem se potencializado como recurso didático por extrapolar as barreiras de uma simples visualização dinâmica de conteúdos. A multimodalidade do vídeo ainda pode 
ser usufruída, porém a produção de vídeos com câmeras digitais e softwares de edição com interfaces amigáveis é tida como característica mais interessante ao lado da facilidade de divulgação e compartilhamento desse tipo de material em plataformas populares como o Youtube.

É exemplo do interesse em pesquisas utilizando vídeo como recurso dentro da área de Educação Matemática o surgimento do Grupo de Pesquisa em Informática, outras mídias e Educação Matemática (GPIMEM). Os professores-pesquisadores, coordenados pelo professor doutor Marcelo Borba, desenvolvem projetos e estudam a forma como alunos podem utilizar telefones celulares e outros dispositivos móveis, com a intenção de criar, publicar e compartilhar narrativas que abordem questões do ensino e da aprendizagem de Matemática.

Criado a partir da percepção da familiaridade que os jovens possuem ao lidar com vídeos, Borba (2018) aponta que o grupo busca "pesquisar a produção de vídeos com conteúdo matemático por alunos, buscando entender, dentre outras questões, a maneira com que eles comunicam ideias matemáticas por meio desse artefato digital" (p.48). Sendo assim, alunos da educação básica e da licenciatura em Matemática são estimulados a produzir vídeos com ideias matemáticas.

A dedicação em pesquisas relacionadas ao uso e produção de vídeos pelo GPIMEM ganhou mais força com o projeto "Vídeos Digitais na Licenciatura em Matemática a Distância", intitulado de E-licm@at-Tube em 2016. O projeto apresentava como objetivo principal a compreensão das possibilidades na construção colaborativa de vídeos na formação de professores (DOMINGUES, BORBA 2018). Um dos eventos organizados pelo projeto, que conta com o apoio da Sociedade Brasileira de Educação Matemática (SBEM) e da agência de fomento CNPq, é o Festival de Vídeos Digitais e Educação Matemática.

Até o atual momento, ocorreram três edições (2017, 2018 e 2019) que foram organizadas em duas etapas. Na etapa inicial, os professores são convidados a submeter vídeos produzidos por seus alunos que contenham ideias e conteúdos matemáticos. Após estes passarem por uma seleção da organização, são compartilhados no site (www.festivalvideomat.com) e ficam disponíveis para todo o público interessado. A etapa final consiste em um evento presencial, na qual são organizadas palestras e mesas-redondas sobre a temática de vídeos estudantis e uma premiação, organizada por uma comissão julgadora, para os melhores vídeos de cada categoria. 
Domingues e Borba (2018) apontam para o fato de que muitos professores que participaram do primeiro festival já possuíam experiências com produção de vídeos em sala de aula e utilizaram o evento para divulgar o trabalho e ganhar visibilidade. Segundo os autores, esse tipo de atividade possui importância de caráter nacional, uma vez que o trabalho é desenvolvido por professores, mas não é divulgado no meio acadêmico.

Tendo em vista o que foi descrito até este momento, é possível ter a clareza de que o vídeo tem grande potencial no que se refere aos aspectos contextuais atuais. Atualmente, o estudante é familiarizado com a utilização do vídeo como pesquisa para fins educacionais (DOMINGUES, 2014) buscando de forma autônoma, na internet, conteúdos que o interessem ou que possam suprir dificuldades e dúvidas. É grande a oferta de aulas-testes, vídeos explicativos, canais de educação e demais conteúdos voltados para a área da educação. Além disso, esse mesmo aluno tem facilidade para produzir vídeos a partir de seus dispositivos eletrônicos pessoais, como tablets e smartphones. (VARGAS, ROCHA, FREIRE, 2007). Cabe, portanto, ao professor aproveitar este cenário propício para oferecer oportunidades fazendo com que seus alunos se utilizem da proximidade com esse recurso e desenvolvam trabalhos neste sentido.

Em relação ao conteúdo trabalhado - no nosso caso, a probabilidade -, tendo em vista que será constantemente revisitado, espera-se uma maior apropriação por parte do aluno. Neste sentido, a criação de um vídeo demandará que ele necessariamente se aproprie do conteúdo para, assim, poder produzir um material claro, coerente e de qualidade.

Corroborando com essa ideia, Lisboa, Junior e Coutinho (2009) mencionam que:

o vídeo como recurso de dinamização do fazer pedagógico, por ser um instrumento de comunicação audiovisual que facilita a assimilação do conteúdo, considerando que a informação se efectiva envolvendo mais de um dos sentidos do aluno, ou seja, além de alcançar o sensorial, envolve também o afectivo, o que de certa forma, aproxima do quotidiano do educando e facilita o entendimento do conteúdo abordado (p. 2).

Além disso, certamente esse trabalho propicia o desenvolvimento de outras habilidades e competências. Segundo os autores, a utilização do vídeo deve 
possibilitar ao aluno analisar os diferentes estilos de linguagem e os aspectos positivos e negativos das diversas mensagens apresentadas.

Com o objetivo de produzir um material audiovisual, o aluno precisará tomar contato com conhecimentos (prévios ou não), sobre a utilização dessa tecnologia, assim como as ferramentas de edição, e as diversas linguagens que 0 vídeo possibilita (imagens, texto, som etc.).

Mais especificamente, pensando na proposta que será apresentada nesta pesquisa, podemos ver a utilização do vídeo como recurso fundamental no que diz respeito à reflexão do aluno diante das diferentes abordagens que se dá à probabilidade. Nesse sentido, o vídeo pode ajudá-lo a sair de respostas mais determinísticas, permitindo com que tenha acesso a exemplificações mais claras e concretas de situações que trabalhem com ideias conceituais sobre eventos de natureza aleatória.

Retomando a perspectiva de Batanero (2005) apresentada no capítulo anterior, os diversos significados de probabilidade e muitos de seus elementos de significado podem ter sua abordagem mais facilitada em uma produção audiovisual por contar com um fator de dinamismo característico desse recurso. Mesmo em vídeos de curtos - com cerca de 4 ou 5 minutos - pode-se apresentar aspectos relacionados ao significado intuitivo, com entrevistas, depoimentos ou dramatizações e, também abordar elementos presentes no significado clássico (laplaciano) como fórmulas e suas aplicações. Ao se pensar nas possibilidades de abordagem do significado frequencial, vê-se o vídeo também como agente facilitador de observação de séries de ensaios de experimento, simulações e análises de resultados advindos de levantamentos estatísticos.

\subsection{Aspectos técnicos na criação de vídeos}

Ao deparar-se com a proposta de produção de vídeo em sala de aula, certamente surgem demandas técnicas diretamente relacionadas à concepção do vídeo e à sua execução. Neste momento, os alunos podem valer-se de conhecimentos que já possuem e contribuírem para a produção do grupo. No entanto, caso seja necessário, o professor deve ter certo repertório a respeito dos principais processos envolvidos na produção de um vídeo para auxiliar os alunos na confecção. 
Desta forma, serão apresentadas aqui, algumas ideias e informações que podem ser utilizadas durante a aplicação do projeto juntamente com os alunos.

Vargas, Rocha e Freire (2008) separam a produção total de um vídeo em três grandes etapas, são elas: (1) a pré-produção, que consiste na preparação e planejamento do material a seu produzido, (2) a produção, que caracteriza-se pelo momento em que são realizadas as filmagens das cenas que compõem o vídeo e (3) a pós produção, na qual está presente o momento de organização e edição das cenas já gravadas e composição do vídeo como um todo. Nos próximos subitens, apresentaremos aspectos relacionados a essas três etapas.

\subsubsection{Roteirização}

Tão pronta seja a decisão sobre o tema a ser desenvolvido no vídeo, há uma inquietação em relação às gravações. É normal que os alunos, em confecção de vídeos estudantis, apresentem grande anseio em acionar as filmadoras de seus celulares assim que cheguem a um consenso sobre o conteúdo principal. No entanto, há um importante processo que não deve ser negligenciado: a criação do roteiro. É nesse momento que grandes discussões e reflexões em relação ao tema poderão aparecer e uma certa dedicação em pesquisas faz-se necessário para um melhor aprofundamento do tema. Segundo Oechsler, Fontes e Borba (2017) "o roteiro deverá conter todas as informações necessárias para as filmagens, não importando seu formato, e deve ser compreendido por todos os envolvidos no trabalho".

A ausência do roteiro pode gerar não só uma falta de profundidade nas questões a serem expostas no vídeo, como pode deixá-lo sem direcionamento, objetivo claro ou com uma narrativa confusa. Uma estratégia interessante para auxiliar os alunos no processo de roteirização consiste em proporcionar um espaço para que os estudantes, após levantamento de ideias no grupo, exponham um esqueleto do roteiro para os demais colegas. Ao apresentar as ideias para a turma, um integrante se responsabiliza por realizar o registro da discussão. Esse material servirá como consulta na hora de colocar no papel o roteiro da gravação. É esperado que, ao longo da exposição do grupo, os alunos de outros grupos forneçam considerações e sugestões. 
É importante que os grupos tenham objetivos de contemplar no roteiro uma breve descrição das cenas e dos acontecimentos entre elas, as falas e as narrações presentes no vídeo, algumas indicações de inserção de animação, legendas e efeitos sonoros, a definição do cenário e os figurinos dos eventuais atores. A forma como é confeccionado o roteiro pode e deve variar, o importante é que contenha as informações principais listadas acima e seja facilmente compreendido por todos os envolvidos na criação do vídeo.

É durante o planejamento e confecção do roteiro que os grupos realizam uma escolha muito importante: o gênero do vídeo. A forma geral como os produtores do vídeo vão se comunicar com 0 público desejado pode variar entre narrativa/encenação, vídeo com slides, captura de tela com narração, animação, stopmotion, vídeo aula, entre outros.

Em geral é esperado que os alunos se organizem de forma que consigam escrever o roteiro coletivamente. Deste modo, a responsabilidade da função de roteirista é dividida entre todos os estudantes do grupo. Restam ainda algumas atribuições importantes no trabalho de confecção de um vídeo, como: atores, produtor, diretor e, posterior às gravações, editor. É importante que o momento de divisão de tarefas seja após a elaboração do roteiro, para que os alunos avaliem se estão confortáveis ou não para assumir uma determinada função.

\subsubsection{Gravação e edição}

Após uma roteirização detalhada, criada de maneira qualificada, as gravações devem ser facilitadas por já haver um direcionamento claro das ações dessa etapa. No entanto, os desafios dessa etapa não são poucos. Primeiramente há de se realizar decisão em relação ao dispositivo a ser utilizado - celular, tablet, câmera digital, filmadora, entre outros - pois a qualidade da imagem gerada por esses equipamentos contribui diretamente para o resultado final do seu vídeo (OESCHLER, FONTES e BORBA 2017). No entanto, os autores apontam para outros cuidados no momento das filmagens que podem ser observados no quadro abaixo. 
Quadro 7 - Aspectos relevantes na hora das filmagens

\begin{tabular}{|l|l|}
\hline Tripé ou apoio & $\begin{array}{l}\text { Ele auxilia a estabilizar a imagem, evitando as imagens tremidas e } \\
\text { distorcidas. }\end{array}$ \\
\hline Iluminação & $\begin{array}{l}\text { Essencial para garantir boas imagens. A verificação da luz e sombra faz- } \\
\text { se necessária tanto em ambientes internos quanto externos. }\end{array}$ \\
\hline Som & $\begin{array}{l}\text { As interferências externas e volume da voz de personagens do filme } \\
\text { influenciam diretamente na qualidade da produção. }\end{array}$ \\
\hline Resolução & $\begin{array}{l}\text { É importante o cuidado na escolha da resolução que será utilizada para } \\
\text { a captação das imagens, pois resoluções baixas, ao serem } \\
\text { reproduzidas, geram imagens de má qualidade }\end{array}$ \\
\hline
\end{tabular}

Fonte: Oeschler, Fontes e Borba (2017)

Além dos aspectos apresentados acima, os autores apontam para a reflexão acerca dos planos e enquadramentos das filmagens. Segundo Oeschler, Fontes e Borba (2017) existem diversos tipos de plano, como: (1) o plano geral, mais aberto, em que a informação predominante é o cenário, (2) o plano conjunto, que prioriza a interação entre os personagens, (3) o plano médio, no qual o destaque é para um personagem em especial, (4) o primeiro plano, que dá ênfase às expressões faciais e (5) o plano detalhe, que registra detalhes de objetos.

Quadro 8 - Diferentes planos de filmagem

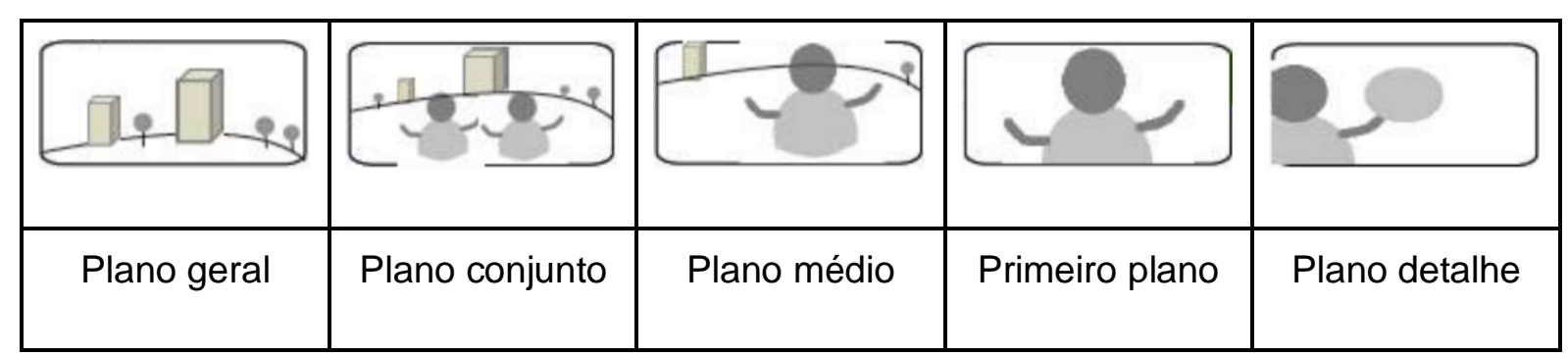

Fonte: Oeschler, Fontes e Borba (2017)

Retomando a característica de multimodalidade presente nos vídeos, há a possibilidade de inclusão na produção audiovisual de outras captações de imagens, como gravações de áudio, gravação de tela de computadores e animações criadas virtualmente. Tais recursos favorecem a não linearidade de textos, colaborando desta maneira para a abordagem de conceitos de múltiplas formas.

Os programas de edição variam bastante em relação às ferramentas e recursos que disponibiliza aos usuários. Como trata-se de vídeos amadores 
confeccionados por estudantes, a pesquisa por softwares concentrou-se em programas de interface amigável, fácil manipulação - por consequência, com poucos recursos - e livres, disponibilizados na internet sem custo.

Os programas para computador que obtiveram maiores destaques na pesquisa foram:

$\begin{array}{ll}\text { - } & \text { OpenShot } \\ \text { - } & \text { ApowerEdit } \\ \text { - } & \text { Davinci Resolve } \\ \text { - } & \text { Filmora } \\ \text { - } \quad \text { Jahshaka }\end{array}$

Dentre os programas listados acima, o editor OpenShot se mostrou o mais adequado para ser apresentado aos alunos ao longo do projeto, caso seja necessário, pois pode ser utilizado com recursos automáticos e de uma maneira amadora, mas também há possibilidade de o usuário interagir com as propriedades dos objetos de um modo um pouco mais profissional.

No apêndice há uma breve apresentação de algumas funcionalidades do editor OpenShot e os recursos básicos que podem ser utilizados pelos alunos na confecção de seus vídeos estudantis.

Pelas experiências que serão relatadas nesta dissertação, é possível notar que alguns alunos já possuem não só conhecimento prévio de edição, como um programa favorito de edição de vídeos. Por vezes são programas pagos, com mais recursos e ferramentas, que já estão instalados em seu computador pessoal, smartphone ou tablet. É importante destacar que os estudantes podem optar pelo uso de qualquer programa diferente dos listados acima. Como já foi citado, a apresentação de um programa de edição elementar é um ponto de partida para novos aventureiros nessa jornada audiovisual.

De maneira geral, a maioria dos programas de edição de vídeos apresentam os seguintes recursos básicos que podem ser utilizados pelos alunos: a ordenação de tomadas, possibilitando encaixar seus trechos de gravação na ordem de seu interesse e dispensando a necessidade de realizar a gravação na ordem que se deseja apresentar ao espectador. Os cortes nas tomadas, permitindo o descarte de cenas que não serão úteis na versão final. Os ajustes de contraste, brilho e nitidez, 
viabilizando os ajustes técnicos necessários e a sobreposição de texto, imagem e áudio, concedendo aos criadores do vídeo a oportunidade de adicionar alguma representação complementares típica da multimodalidade dos vídeos. 


\section{A proposta de aplicação}

Elaborar a proposta de aplicação para a presente pesquisa foi um processo longo no qual diferentes etapas, questionamentos e reflexões contribuíram para a proposta final. Considerando as ideias apresentadas no Capítulo 3 acerca da relevância do uso das tecnologias em sala de aula, pensou-se em elaborar uma proposta na qual o aluno se colocasse como protagonista em seu processo de aprendizagem (MORAN 2018). Tal proposta visava a utilização do recurso do vídeo para desenvolvimento de conceitos importantes relacionados ao ensinoaprendizagem de probabilidade abordados no Capítulo 2.

O atual capítulo inicia-se com uma apresentação e breve análise de uma primeira experiência do pesquisador com o uso do vídeo em sala de aula, na qual houve grande aproximação ao tema. Feito isso, serão apresentados aspectos metodológicos referentes à pesquisa qualitativa em Educação Matemática e descrição do planejamento das ações da aplicação da proposta. Por fim, serão descritos os estudos realizados pelo grupo de alunos antes da aplicação e o detalhamento de todo o desenvolvimento do projeto.

\subsection{Uma primeira experiência do uso do vídeo em sala de aula.}

Com a intenção de aproximação ao tema e experimentação, foi realizado, nos meses de outubro e novembro do ano de 2017, um projeto-piloto com o uso de vídeo. Ele foi desenvolvido em uma escola particular da zona oeste de São Paulo, utilizando o vídeo como recurso didático para o ensino de tópicos de Estatística. Essas aulas utilizadas foram inseridas dentro do curso de Matemática cujo docente responsável pela disciplina era o pesquisador.

A decisão de sua realização foi tomada pouco tempo antes de sua aplicação, com a ideia de fazer uma primeira experiência e de se aproximar dessa prática, para, posteriormente, ter maiores referências, repertórios e informações ao fazer a elaboração do projeto final a ser aplicado na pesquisa. Deste modo, não houve muito tempo para a realização de um planejamento mais detalhado e embasado. As etapas e toda a sua constituição foram pensadas a partir das vivências em sala de aula e das primeiras pesquisas relacionadas ao tema escolhido. 
Neste capítulo, será relatada essa experiência, acompanhada de algumas considerações a respeito dos aspectos positivos e negativos observados durante 0 projeto. Essa aplicação foi importante, pois norteou uma série de decisões que foram tomadas para o planejamento do projeto final. Sendo assim, as observações e análises que serão relatadas foram importantes na elaboração da proposta final.

\subsubsection{Descrição das atividades}

$\mathrm{Na}$ aplicação do projeto, ao todo, foram utilizadas 10 aulas com duração de 1 hora e 15 minutos para cada uma das três turmas de $7^{\circ}$ ano do Ensino Fundamental, contando com 30 alunos em cada. Na primeira aula, foi apresentada a proposta de se trabalhar os conteúdos previstos para o final do ano de uma maneira diferente do método tradicional de ensino, promovendo a mudança do modo expositivo, que utiliza apenas lousa e caderno como recurso, para uma maneira que utilizasse o vídeo e atividades investigativas em grupo. Tais conteúdos diziam respeito às características gerais da Estatística, como pesquisa estatística, amostra e população, tipos de variáveis, medidas de tendência central e também às noções iniciais de probabilidade. Para isso, os alunos receberam textos e atividades visando o aprofundamento de conceitos relacionados ao tema e, ao final do trabalho, houve o planejamento e a produção de um vídeo didático que abordou o conteúdo pesquisado.

Após a apresentação de um cronograma inicial para os alunos, foram exibidos dois vídeos, com características distintas, que abordavam os temas probabilidade e estatística. A intenção desse primeiro momento era aproximar o aluno dos temas que seriam trabalhados, fornecer exemplos de vídeos didáticos diferentes de videoaulas e realizar uma avaliação do modo como o aluno se relaciona com questões apresentadas na forma de vídeo. Para tal avaliação, os alunos foram divididos em grupos para discutirem a respeito dos conceitos que foram tratados nos vídeos e, posteriormente, responderam a dois questionários no formato de formulário eletrônico.

Ao fim da primeira aula, os alunos, de maneira individual, ainda responderam a mais um questionário. Desta vez, as perguntas eram direcionadas à motivação do estudante em relação à proposta de trabalho apresentada e à familiaridade com a criação e edição de vídeos. 
Na segunda aula, foram apresentados aos alunos os grupos de trabalho e foram levantados coletivamente os critérios essenciais para a criação de um bom vídeo didático e houve a socialização de estratégias para a filmagem e edição dos vídeos.

Durante as quatro aulas seguintes, cada grupo de trabalho recebeu duas fichas com textos, sugestões de vídeos, atividades e exercícios de acordo com seu tema. Por se tratar de atividades investigativas, os alunos foram encaminhados a ler com atenção e debater cada tópico antes de criar seus registros no caderno. Assim que completavam seus registros, os alunos deveriam iniciar a próxima etapa do trabalho confeccionando o roteiro do vídeo. Para isso, a instrução foi destacar algum ponto interessante que foi desenvolvido nas aulas anteriores para explorar, explicar ou exemplificar na forma de vídeo. Feito isso, os alunos tiveram a liberdade de circular pela escola gravando com seus tablets e celulares e, posteriormente, editar utilizando seus dispositivos.

As aulas seguintes consistiam na apresentação dos vídeos para os demais alunos da sala. Essa etapa foi reduzida a uma aula por conta da maior duração das etapas anteriores. Foi aplicado um último questionário a fim de criar um momento de autoavaliação do processo e coletar informações a respeito das considerações finais dos alunos sobre o todo o processo.

A última aula tinha por objetivo a exibição dos vídeos para uma banca formada por professores de outras matérias e coordenadores que trariam outras considerações a respeito dos vídeos e avaliariam as produções dos alunos. Pela mesma razão supracitada, esta etapa ficou comprometida e não ocorreu.

A tabela abaixo relaciona o cronograma inicial com a efetiva duração do projeto.

Quadro 9- Comparação do cronograma com a efetiva duração do projeto

\begin{tabular}{|c|c|c|}
\hline Tema & Cronograma inicial & $\begin{array}{c}\text { Efetiva duração do } \\
\text { projeto }\end{array}$ \\
\hline Apresentação, vídeos e questionários. & 1 aula & 1 aula \\
\hline Separação de grupos e critérios. & 1 aula & 1 aula \\
\hline Pesquisa, leitura, atividades e exercícios. & 3 aulas & 4 aulas \\
\hline Roteiro e confecção do vídeo. & 2 aulas & 3 aulas \\
\hline Apresentação dos vídeos. & 2 aulas & 1 aula \\
\hline
\end{tabular}




\begin{tabular}{|c|c|c|}
\hline Banca externa de avaliação. & 1 aula & 0 aula \\
\hline TOTAL DE AULAS & 10 aulas & 10 aulas \\
\hline
\end{tabular}

\subsubsection{Do projeto-piloto ao projeto final: contribuições e mudanças}

De maneira geral, a experiência com a utilização do vídeo em sala de aula atingiu o objetivo principal de aproximação ao tema e ampliação de estratégias para o desenvolvimento do projeto final. A maior contribuição dessa primeira experiência está relacionada à decisão do percurso a ser desenvolvido com os alunos.

Algumas questões certamente foram revistas para a melhor elaboração do plano de trabalho. A principal delas é a opção por apenas um tema de trabalho, por conta da dificuldade notada no trato do professor com duas temáticas simultâneas. Sendo assim, o trabalho focou-se apenas a introdução aos conceitos relacionados à probabilidade e suas diferentes abordagens.

Dentre os questionários, o questionário relacionado às expectativas e familiaridade técnica foi replicado e usado como base para a elaboração de um novo questionário do projeto. Também decidiu-se por manter um último questionário de avaliação do processo. No entanto, foi prevista a inclusão de questões relacionadas ao avanço conceitual dos alunos, recuperando aspectos abordados nos questionários iniciais. Deste modo, haverá possibilidade de realizar comparações futuras. Além disso, para ampliar a possibilidade de análise, notou-se importante a realização de entrevistas individuais e em grupo.

Decidiu-se também por manter a organização geral do percurso do trabalho, que inclui uma etapa de estudo anterior à produção do vídeo, uma etapa de preparação e criação de roteiro, uma etapa de produção do vídeo e, por fim, uma etapa de apresentação dos vídeos, análise e discussão sobre os produtos finais.

Em relação a essa última etapa, vale ressaltar que, no projeto-piloto, não foi possível fazer as análises e discussões com qualidade, pois não houve tempo hábil para isso dentro do curso de matemática. Sendo assim, foi importante prever, para o projeto final, um tempo maior para esse momento. 


\subsection{Metodologia da aplicação}

A metodologia escolhida para a aplicação do projeto tem caráter qualitativo. Neste capítulo, serão apresentadas as características principais da pesquisa qualitativa na área de Educação Matemática e as análises das leituras que foram realizadas a fim de estabelecer uma direção mais clara para a pesquisa e auxiliar na análise da aplicação e validação da pesquisa.

Em busca de compreensões e interpretações significativas a respeito da questão de pesquisa formulada, os pesquisadores da área de Educação Matemática necessitam um olhar analítico rigoroso. Segundo Borba e Araújo (2004), esse tipo de pesquisa tem se expandido na área de Educação Matemática. Diversos pesquisadores têm validado suas reflexões científicas utilizando diferentes modalidades de metodologia dentro da pesquisa qualitativa.

Segundo Garnica (2004) são características da pesquisa qualitativa:

(a) a transitoriedade de seus resultados; (b) a impossibilidade de uma hipótese a priori, cujo objetivo da pesquisa será comprovar ou refutar; (c) a não neutralidade do pesquisador que, no processo interpretativo, vale-se de suas perspectivas e filtros vivenciais prévios dos quais não consegue se desvencilhar; (d) que a constituição de suas compreensões dá-se não como resultado, mas numa trajetória em que essas mesmas compreensões e também os meios de obtê-las podem ser (re)configuradas; e (e) a impossibilidade de estabelecer regulamentações, em procedimentos sistemáticos, prévios, estatísticos e generalistas (p.86).

Tais características evidenciam o caráter subjetivo das pesquisas qualitativas, indicando que essa modalidade de pesquisa baseia-se na relação humana. É de interesse desse tipo de pesquisa compreender as atitudes e pensamentos que determinados grupos de pessoas possuem em relação a certos assuntos. Dessa maneira, o olhar é destinado à trajetória e não a um simples resultado. Por enfatizar a qualidade das entidades envolvidas, e não a quantidade, fica estabelecida a impossibilidade de se comprovar ou refutar uma eventual hipótese inicial, tal qual a impossibilidade de estabelecer regulamentações em processos sistemáticos, prévios, estatísticos e generalistas. Reforçando essa ideia, Goldenberg (2004) afirma que nas pesquisas de cunho qualitativo, a preocupação do pesquisador "não é com a 
representatividade numérica do grupo pesquisado, mas com o aprofundamento da compreensão de um grupo social, de uma organização, de uma instituição, de uma trajetória etc. "(p.14).

A área de Educação Matemática, por ter seu surgimento por volta dos anos 50, configura-se ainda como uma região de pesquisa em construção. Em relação às pesquisas qualitativas, o cenário não é diferente. Em Educação Matemática "o próprio entendimento do que é pesquisa qualitativa está em movimento e as noções acima levam a ênfases diferentes" (BORBA, 2004, p.2). O que temos como consolidação nas pesquisas qualitativas é que a descrição dos procedimentos é essencial, pois as visões desse tipo de inquérito admitem interferências subjetivas. O que é tido como certo e verdadeiro é sempre dinâmico e passível de ser mudado.

A concepção de validade nas pesquisas qualitativas não é tão trivial quanto nas pesquisas quantitativas por conta de não apresentarem essa questão como um atributo que se relaciona com a objetividade (OLLAIK e ZILLER, 2012). Segundo os autores, essa concepção "assume formas distintas, pois a discussão sobre escalas de medição não se aplica aos métodos qualitativos, sendo necessária a compreensão da validade em outra perspectiva" (p. 232).

Como o objetivo dessas pesquisas é a descrição e compreensão de um fenômeno, verificar a validade de pesquisas nessa área é determinar se a mesma possui processos metodológicos coerentes e resultados consistentes. É fundamental a descrição minuciosa dos fatos e a regressão constante nos referenciais teóricos metodológicos. Há grande responsabilidade dos pesquisadores no tratamento dos dados obtidos, envolvendo dessa maneira, intensa preocupação ética.

Para tanto, será importante considerar a pergunta de pesquisa bem como questões contextuais que possibilitem a realização da pesquisa de forma a atingir os objetivos propostos.

Foram utilizados, para a preparação da proposta, alguns fundamentos de uma metodologia específica da Educação Matemática denominada Experimento de Ensino. Abordada e descrita por Steffe e Thompson (2000), essa metodologia busca a compreensão de transformações da matemática utilizada pelos estudantes. Segundo os autores, o experimento de ensino é uma sequência de encontros do professor pesquisador com seu grupo de alunos denominados episódios, e têm como características principais a experimentação e a interação entre pesquisador e estudantes na produção de conhecimento. 
De acordo com os autores, essa metodologia não surgiu de maneira padronizada e nem foi padronizada desde então. É uma ferramenta conceitual e exploratória, que pesquisadores usam na organização de suas atividades visando explorar a matemática desenvolvida por seus estudantes. Tal metodologia carrega a característica de ser uma maneira dinâmica de atuação e tem papel funcional na atuação do pesquisador, pois organiza seus objetivos e propósitos ao longo de seu trabalho.

De acordo com Scucuglia (2006 p. 23), "Os experimentos de ensino possibilitam, essencialmente, a estruturação de modelos da matemática de estudantes na exploração de atividades matemáticas." É durante as sessões de experimento, analisando o desenvolvimento do aluno diante das atividades propostas, que conjecturas são criadas e permitem a identificação das variações epistemológicas no processo de investigação.

A leitura e interpretação que o autor faz da descrição de Steffe e Thompson (2000), corroboram com as ideias de Borba e Araújo (2004) que afirma que:

\footnotetext{
É possível que o pesquisador valorize a voz dos estudantes de forma especial, trazendo-a para a pesquisa, tentando construir modelos que validem a Matemática do aluno, em contraposição a testes ou mesmo análises que enfocam o erro. Nesse sentido é inegável que o experimento de ensino expressa de forma eloquente ao menos um dos princípios da pesquisa qualitativa: fazer com que o humano apareça e não se esconda atrás de estatísticas (Borba e Araújo, 2004).
}

Fica evidente que a modalidade de pesquisa em questão tem foco no processo, na interação professor-aluno, no desenvolvimento da matemática dos estudantes. Os Experimentos de Ensino contemplam principalmente uma das características da pesquisa qualitativa já citada e proposta por Garnica (2004) que "a constituição de suas compreensões dá-se não como resultado, mas numa trajetória em que essas mesmas compreensões e também os meios de obtê-las podem ser (re)configuradas" (p. 86).

A metodologia de Experimentos de Ensino baseia-se em uma busca pela estruturação do processo cognitivo de estudantes fornecido por uma sequência de episódios de ensino, que se estendem por um determinado período, entre estudantes 
e pesquisador. São elementos dessa sequência: o agente de ensino, um ou um grupo de estudantes, testemunha dos episódios e um método de gravação.

De acordo com os autores, os registros são fundamentais para a análise minuciosa dos acontecimentos que ocorrem ao longo dos episódios e recuperam importantes detalhes que ocasionalmente não foram constatados pelo professorpesquisador no momento da realização da atividade. Essas gravações devem ser utilizadas nos preparos de episódios subsequentes e na análise conceitual retrospectiva do experimento.

Vale ressaltar que a presente pesquisa utilizará as ideias dessa metodologia de pesquisa apenas como base e que não pretende-se aqui seguir com rigor todos os pontos e características do experimento de ensino descritos por Steffe e Thompson (2000).

\subsection{Apresentação da proposta}

Buscando responder à pergunta norteadora apresentada no início desta dissertação propõe-se aqui uma sequência de atividades utilizando a criação de vídeos e discussões baseadas na análise das produções dos alunos com três salas de nonos anos do Ensino Fundamental.

O objetivo principal dessa sequência de atividades é a compreensão da noção de acaso e aleatoriedade, que está diretamente relacionado ao conteúdo de probabilidade programado para os anos finais do Ensino Fundamental.

Todo o planejamento dessa sequência foi realizado levando em consideração (1) as leituras realizadas em relação aos temas que envolvem essa pesquisa cujas principais informações e reflexões encontram-se nos Capítulos 2 e 3; (2) as características particulares do contexto no qual seria realizada a intervenção (escola, idade dos alunos, tempo disponível para aplicação, dentre outros); (3) as análises e conclusões levantadas a partir da realização do projeto piloto descrito no início deste capítulo.

Diferente da primeira experiência relatada, este processo consiste em uma intervenção nas aulas de Matemática de um outro professor. Sendo assim, as energias não foram direcionadas na elaboração de uma sequência didática para introdução dos conceitos de probabilidade, pois era previsto que os alunos 
realizassem as primeiras investigações com seu professor (os estudos pré aplicação serão descritos no Subitem 4.4.1). Assim, as reflexões e desdobramentos ficaram baseadas nesta proposta de intervenção. É importante esclarecer que a classificação professor-pesquisador será desmembrada em professora (atual docente que ministra as aulas para os alunos em questão) e pesquisador (autor desta dissertação de mestrado).

A duração prevista para o desenvolvimento total da atividade é de 7 aulas de 45 minutos cada, que serão distribuídas em um intervalo de aproximadamente um mês, conforme pode-se observar no quadro abaixo.

Quadro 10 - Distribuição das aulas do projeto

\begin{tabular}{|c|c|c|c|c|}
\hline Segunda & Terça & Quarta & Quinta & Sexta \\
\hline \multirow[t]{2}{*}{$25 / 03$} & $26 / 03$ & $27 / 03$ & $28 / 03$ & $29 / 03$ \\
\hline & & & Aulas 1 e 2 & Aula 3 \\
\hline \multirow[t]{2}{*}{$01 / 04$} & $02 / 04$ & $03 / 04$ & $04 / 04$ & $05 / 04$ \\
\hline & Contraturno 1 & & & Aula 4 \\
\hline \multirow[t]{2}{*}{$08 / 04$} & $09 / 04$ & $10 / 04$ & $11 / 04$ & $12 / 04$ \\
\hline & Contraturno 2 & & & \\
\hline \multirow[t]{2}{*}{$15 / 04$} & $16 / 04$ & $17 / 04$ & $18 / 04$ & $19 / 04$ \\
\hline & Contraturno 3 & & Aulas 5 e 6 & Aula 7 \\
\hline
\end{tabular}

A sequência de atividades pode ser dividida em quatro blocos: (1) apresentação da proposta, (2) roteirização, (3) gravação e edição e (4) análise das produções. Há a possibilidade de se instituir uma etapa, denominada análise das reelaborações dos vídeos. No entanto, a ocorrência dessa última fica condicionada à decisão da professora sobre a viabilidade ao fim das análises dos vídeos na quarta etapa.

Inicialmente, os alunos serão apresentados ao pesquisador e à proposta de construção do vídeo: a elaboração de uma apresentação audiovisual que aborde algum aspecto recente relativo às ideias iniciais de probabilidade desenvolvidas nas aulas de Matemática do 9o ano. Para isso, como forma de recuperar algumas investigações e descobertas realizadas pela turma nos estudos pré aplicação, a primeira aula é destinada a um levantamento dos temas desenvolvidos nas aulas 
anteriores. É desejável retomar as constatações realizadas nas últimas aulas para estimular a memória dos estudantes daquelas turmas e resgatar detalhes que já poderiam ter se perdido pelo esquecimento. Espera-se que enquanto forem recuperando os pormenores de suas vivências com as noções de acaso, aleatoriedade e probabilidade, os alunos possam realizar escolhas sobre qual aspecto será mais interessante abordar em sua produção. Neste momento, acredita-se que se evidenciem diversas considerações dos alunos a respeito de suas compreensões sobre o objeto matemático em questão. Pensando em uma futura análise, haverá a gravação de áudio da discussão coletiva presente nessa etapa. Após realização desse levantamento, é prevista a apresentação de algumas modalidades de vídeos para que os alunos iniciem reflexões a respeito de qual modalidade pode potencializar a abordagem desejada. Ao final desta aula pretende-se confeccionar uma nuvem de palavras, que será descrita e apresentada no capítulo de análise.

Na segunda aula, um questionário individual será aplicado em cada turma para futuras análises a respeito do nível de compreensão dos temas propostos pela professora nas aulas que antecederam o projeto. A elaboração das questões teve propósito de sondagem da percepção dos alunos sobre o conceito de aleatoriedade, da capacidade de apresentação de respostas que levassem em consideração as incertezas do cálculo da probabilidade e também, em alguns momentos, da competência para listar possibilidades e apontar um valor numérico para probabilidades solicitadas. Além de questões relacionadas ao conteúdo matemático, o questionário ainda solicita do aluno alguns nomes de colegas considerados boas parcerias de trabalho e o nível de familiaridade com criação e edição de vídeos.

Os grupos de trabalho serão determinados pela professora, que utilizará dados observados no questionário, e apresentados para os alunos no início da terceira aula. Os alunos, preferencialmente, serão agrupados em quintetos e, durante essa etapa espera-se que possam dialogar com seus colegas a respeito de suas preferências de tema central para a construção do vídeo e modalidade audiovisual que melhor se encaixa naquele conteúdo. O papel do pesquisador fica destinado a uma constante visitação nos grupos, buscando o que Steffe e Thompson (2000) denominou como interação entre pesquisador e estudantes na produção de conhecimento.

O objetivo dessa etapa consiste em que um representante de cada grupo apresente aos demais um relato da discussão e a sala aponte suas observações e complementos para que, na quarta aula, todos os estudantes possam iniciar a 
confecção do roteiro do vídeo. Para essa elaboração, os alunos receberão um documento (ver apêndice) para a produção de roteiro.

Finalizada a quarta aula, os alunos devem apresentar um planejamento de suas próximas ações e espera-se que já possam iniciar o momento de gravações. Também como forma de orientação sobre aspectos técnicos de gravação e edição, os alunos receberão um documento, baseado em Oeschler, Fontes e Borba (2018) que aponta para alguns cuidados e exibe recomendações e propostas.

Como foi salientado pela professora em conversa que antecedeu a elaboração desta proposta, os alunos em questão já possuem familiaridade com criação e edição de vídeo. Desta maneira, foi destinado apenas uma aula às gravações e edições. No entanto, outras aulas de Matemática relacionadas aos demais assuntos presentes no planejamento anual do curso ocorrerão entre a quinta aula e a apresentação das produções. Assim, os estudantes terão tempo de aproximadamente duas semanas para se dedicar ao processo de criação do vídeo e, ao longo desse intervalo, duas consultorias com o pesquisador serão disponibilizadas aos alunos no contraturno.

As apresentações estão previstas para a sexta e sétima aulas oficiais da turma com o pesquisador e, após cada exibição de vídeo, um momento de diálogo coletivo será aberto a fim de se destacar os aspectos positivos abordados na produção e de se refletir sobre propostas de melhorias do material apresentado. Durante esse momento, espera-se que apareçam muitas colocações que se caracterizarão como fonte de análise da aplicação do projeto. Para viabilizar a análise posterior, esta etapa terá gravadores de áudio espalhados em locais estratégicos da sala.

Caso a última etapa seja avaliada como viável pela professora, ao final das apresentações, os grupos serão orientados a realizar algumas mudanças em sua produção, buscando contemplar as observações e sugestões da sala e realizar nova apresentação dos vídeos na aula seguinte.

O quadro abaixo apresenta, de maneira sintetizada, a descrição de cada aula e os instrumentos de captação de dados para análise final da aplicação. Tais instrumentos serão descritos com mais detalhes no próximo item deste capítulo. 
Quadro 11 - Descrição detalhada das aulas do projeto

\begin{tabular}{|c|c|c|}
\hline & Descrição & Instrumentos de pesquisa \\
\hline Aula 1 & $\begin{array}{l}\text { Apresentação do pesquisador } \\
\text { Apresentação da proposta de construção } \\
\text { do vídeo } \\
\text { Apresentação de modalidades de vídeos } \\
\text { Questionário de sondagem }\end{array}$ & $\begin{array}{l}\text { Gravação do áudio do levantamento } \\
\text { dos temas } \\
\text { Questionário de sondagem }\end{array}$ \\
\hline Aula 2 & $\begin{array}{l}\text { Separação em grupos de trabalho } \\
\text { Levantamento de ideias para construção } \\
\text { do roteiro } \\
\text { Apresentação das ideias para a sala }\end{array}$ & $\begin{array}{l}\text { Gravação do áudio das discussões dos } \\
\text { grupos, das apresentações das ideias } \\
\text { iniciais e das observações da turma. }\end{array}$ \\
\hline $\begin{array}{l}\text { Aulas } \\
3 \text { e } 4\end{array}$ & Escrita do roteiro & $\begin{array}{l}\text { Gravação do áudio das discussões dos } \\
\text { grupos, das apresentações das ideias } \\
\text { iniciais e das observações da turma. } \\
\text { Roteiro do vídeo }\end{array}$ \\
\hline $\begin{array}{l}\text { Aulas } \\
5 \text { e } 6\end{array}$ & $\begin{array}{l}\text { Apresentação e discussão das } \\
\text { produções dos alunos } \\
\text { Indicações de aspectos relevantes para } \\
\text { a reelaboração do vídeo }\end{array}$ & $\begin{array}{l}\text { Vídeos da } 1 \text { a apresentação } \\
\text { Gravação do áudio da discussão } \\
\text { coletiva }\end{array}$ \\
\hline Aula 7 & Questionário final & Questionário final \\
\hline Aula 8 & $\begin{array}{l}\text { Apresentação final dos vídeos } \\
\text { produzidos }\end{array}$ & Vídeos da apresentação final \\
\hline
\end{tabular}

\subsubsection{Instrumentos de pesquisa}

A escolha dos instrumentos de pesquisa é fundamental para a análise posterior à aplicação do projeto e para favorecer a validação da pesquisa em sua totalidade. Deste modo, selecionar instrumentos de natureza e modalidades variados faz-se necessário para garantir a verificação do nível de aprofundamento da compreensão dos conceitos a serem trabalhados.

Grande parte da coleta de dados acontecerá em momentos de discussão coletiva. São em situações de reflexão da turma, ora direcionadas pela figura do professor ou pesquisador, ora centralizada em colocações individuais dos alunos, que a interação dos estudantes com os objetivos matemáticos em questão estará mais exposta. Durante o projeto são previstos alguns momentos nos quais serão realizadas 
as gravações, como a apresentação da proposta, a exposição dos rascunhos dos roteiros e as análises das produções da turma.

Além de situações como as descritas no parágrafo anterior, as discussões nos grupos durante a elaboração do roteiro também se caracterizam como um momento rico para coleta de dados. Em todas as ocasiões acima, o instrumento de coleta será o gravador de áudio. Será garantida a gravação de todas as discussões realizadas em grupos.

As produções dos alunos serão coletadas e analisadas após a aplicação da proposta. O roteiro de gravação e os vídeos produzidos são as duas produções exigidas aos alunos que estão diretamente ligadas ao objetivo principal deste trabalho. Esses dois materiais são de extrema importância para a pesquisa e sua posterior análise, pois são justamente as produções que refletem e revelam a forma como o aluno se relaciona com o conteúdo e com a proposta de trabalho.

Ao olhar para esses materiais posteriormente à sua produção, pretende-se observar qual foi a compreensão do aluno em relação ao conteúdo, como ele conseguiu comunicar o seu aprendizado, como foi o seu desempenho ao lidar com a produção do vídeo, qual foi a importância do planejamento para chegar ao objeto final, dentre outros aspectos que podem ser revelados diante desse material.

Com o objetivo de focar o olhar para dois momentos do processo deste projeto, serão aplicados dois questionários que visam investigar o resultado e o impacto da aplicação do projeto. Sendo assim, logo na primeira aula, será utilizado com os alunos o Questionário inicial - de sondagem - e na última, o Questionário final.

O primeiro possui como objetivos gerais a verificação da compreensão de alguns conceitos básicos relacionados à noção de acaso, aleatoriedade e probabilidade. Além disso, o questionário de sondagem busca traçar um panorama geral da turma em relação à motivação com o tema e familiaridade com as gravações e edições. Por sua vez, o Questionário final possui objetivos gerais de constatação dos possíveis efeitos das discussões e reflexões provenientes do processo de criação do vídeo. Para isso, algumas questões propostas no primeiro encontro, serão replicadas para os alunos nesse novo instrumento de pesquisa. Deste modo, constitui-se como objeto de investigação para a pesquisa a análise comparativa dos questionários, de maneira quantitativa e qualitativa.

A tabela abaixo relaciona as questões do Questionário inicial com seu principal objetivo. 
Quadro 12 - Questionário inicial

\begin{tabular}{|c|c|c|c|c|c|}
\hline \multicolumn{5}{|c|}{ Questão } & Objetivo \\
\hline \multicolumn{5}{|c|}{$\begin{array}{l}\text { 1) Ao lançar uma moeda de cinquenta centavos qualquer, } \\
\text { qual é a probabilidade de ela cair com a face "cara" } \\
\text { voltada para cima? Justifique. }\end{array}$} & $\begin{array}{l}\text { Quantificar o grupo de alunos que } \\
\text { destaca a necessidade da garantia do } \\
\text { equilíbrio da moeda. }\end{array}$ \\
\hline \multicolumn{5}{|c|}{$\begin{array}{l}\text { 2) O matemático inglês John Kerrich realizou } 10.000 \\
\text { lançamentos de uma moeda e obteve } 5.067 \text { caras e } \\
4.933 \text { coroas, ou seja, uma frequência de ocorrência da } \\
\text { face "cara" igual a } 50,67 \% \text {. O que podemos afirmar a } \\
\text { respeito da probabilidade de se obter cara em um } \\
\text { lançamento dessa moeda? Justifique. }\end{array}$} & $\begin{array}{l}\text { Analisar quantos alunos afirmarão que a } \\
\text { probabilidade é } 50,67 \% \text { e quantos vão } \\
\text { falar sobre a adoção de eventuais } \\
\text { hipóteses para atribuição de } \\
\text { probabilidade de eventos. }\end{array}$ \\
\hline \multicolumn{5}{|c|}{$\begin{array}{l}\text { 3) Após } 5 \text { lançamentos de uma moeda equilibrada, } \\
\text { constatou-se um resultado de } 5 \text { coroas. Podemos afirmar } \\
\text { que no próximo lançamento a probabilidade de se obter } \\
\text { uma cara é maior do que } 50 \% \text { ? Justifique. }\end{array}$} & $\begin{array}{l}\text { Analisar concepções errôneas a } \\
\text { respeito da atribuição de probabilidade. }\end{array}$ \\
\hline \multicolumn{5}{|c|}{$\begin{array}{l}\text { 4) Marcos olhou o noticiário pela manhã e, ao perceber } \\
\text { que a previsão do tempo indicava que probabilidade de } \\
\text { chuva era de } 95 \% \text {, saiu com seu guarda-chuva para seu } \\
\text { dia de trabalho. Ao voltar para casa, tarde da noite, com } \\
\text { seu guarda-chuva completamente seco, afirmou: "A } \\
\text { previsão estava errada, pois não caiu nenhuma gota de } \\
\text { chuva". Você concorda com Marcos? Justifique. }\end{array}$} & $\begin{array}{l}\text { Analisar compreensão dos alunos a } \\
\text { respeito de experimentos aleatórios. }\end{array}$ \\
\hline \multicolumn{5}{|c|}{$\begin{array}{l}\text { 5) Em três lançamentos de uma moeda equilibrada, qual } \\
\text { é a probabilidade de se obter ao menos duas faces } \\
\text { "cara"? }\end{array}$} & $\begin{array}{l}\text { Analisar a compreensão dos alunos em } \\
\text { relação ao cálculo de probabilidade na } \\
\text { abordagem clássica. }\end{array}$ \\
\hline \multicolumn{5}{|c|}{$\begin{array}{l}\text { 6) José afirmou que, no lançamento de dois dados } \\
\text { equilibrados, a probabilidade de se obter uma soma } 8 \\
\text { juntando os valores das faces voltadas para cima é maior } \\
\text { que a probabilidade de se obter soma } 5 \text {. Você concorda? } \\
\text { Justifique sua resposta. }\end{array}$} & $\begin{array}{l}\text { Analisar a compreensão dos alunos em } \\
\text { relação ao cálculo de probabilidade na } \\
\text { abordagem clássica. }\end{array}$ \\
\hline \multicolumn{5}{|c|}{$\begin{array}{l}\text { 7) Os dados da tabela foram obtidos a partir de um estudo } \\
\text { realizado com } 1000 \text { indivíduos da mesma faixa etária. }\end{array}$} & \multirow{6}{*}{$\begin{array}{l}\text { Analisar a compreensão dos alunos em } \\
\text { relação ao cálculo de probabilidade na } \\
\text { abordagem clássica em uma situaçãc } \\
\text { problema que envolve a leitura de uma } \\
\text { tabela. }\end{array}$} \\
\hline & $\begin{array}{l}\text { Pratica } \\
\text { exercícios } \\
\text { regularmente }\end{array}$ & $\begin{array}{l}\text { Pratica } \\
\text { exercícios } \\
\text { irregularmente }\end{array}$ & $\begin{array}{l}\text { Não } \\
\text { pratica } \\
\text { exercícios }\end{array}$ & Total & \\
\hline $\begin{array}{l}\text { Possui } \\
\text { doença } \\
\text { cardíaca }\end{array}$ & 12 & 28 & 60 & 100 & \\
\hline $\begin{array}{l}\text { Não } \\
\text { possui } \\
\text { doençąa } \\
\text { cardíaca }\end{array}$ & 248 & 512 & 140 & 900 & \\
\hline Total & 260 & 540 & 200 & 1.000 & \\
\hline \multicolumn{5}{|c|}{$\begin{array}{l}\text { Sorteando-se ao acaso um desses indivíduos, calcule a } \\
\text { probabilidade de que ele pratique exercícios } \\
\text { regularmente e possua doença cardíaca. }\end{array}$} & \\
\hline
\end{tabular}


8) Ainda referente aos dados apresentados na tabela do exercício anterior: sorteando-se ao acaso um indivíduo dentre aqueles que praticam exercícios regularmente ou irregularmente, calcule a probabilidade de que ele seja portador de doença cardíaca.

9) De 1 a 10, qual seu nível de motivação para a proposta apresentada na última aula?

Considere 1 como nada motivado e 10 como extremamente motivado.

10) De 0 a 10, qual seu nível de familiaridade com criação e edição de vídeos?

Considere 1 como nenhuma familiaridade e 10 como extrema familiaridade.
Analisar a compreensão dos alunos em relação ao cálculo de probabilidade na abordagem clássica em uma situação problema que envolve a leitura de uma tabela.

Avaliar motivação geral da classe.

É possível classificar as questões em três blocos distintos. O primeiro, que contempla as questões de 1 a 4, contém situações em que o aluno precisa registrar suas considerações conceituais de maneira textual e tem como pretensão analisar as compreensões gerais sobre aleatoriedade. O segundo bloco, é composto pelas questões 5 a 8 e visa sondar a aplicação de conceitos em situações práticas. Por fim, o terceiro bloco pretende classificar alunos em questões relacionadas à motivação em relação à proposta e o nível de familiaridade com aspectos técnicos da criação audiovisual.

O quadro abaixo apresenta as questões que formam o Questionário final.

Quadro 13 - Questionário final

\begin{tabular}{|l|l|}
\hline \multicolumn{1}{|c|}{ Questão } & \multicolumn{1}{c|}{ Objetivo } \\
\hline $\begin{array}{l}\text { 1) Um dado equilibrado foi lançado 20 vezes e não ocorreu } \\
\text { nenhum lançamento no qual a face 6 tenha ficado voltada } \\
\text { para cima. Podemos afirmar que no próximo lançamento a } \\
\text { probabilidade de ocorrer face 6 é maior do que ocorrer } \\
\text { qualquer outra face? Justifique. }\end{array}$ & $\begin{array}{l}\text { Analisar concepçães errôneas a } \\
\text { respeito da atribuição de probabilidade } \\
\text { (comparar com a Questão 3 do } \\
\text { Questionário inicial). }\end{array}$ \\
\hline $\begin{array}{l}\text { 2) Em três lançamentos de uma moeda equilibrada, qual é } \\
\text { a probabilidade de se obter duas caras e uma coroa? }\end{array}$ & $\begin{array}{l}\text { Analisar a compreensão dos alunos } \\
\text { em relação ao cálculo de probabilidade } \\
\text { na abordagem clássica (comparar com } \\
\text { a Questão 5 do Questionário inicial). }\end{array}$ \\
\hline $\begin{array}{l}\text { 3) Thiago lançou dois dados equilibrados } \\
\text { simultaneamente. Qual é a probabilidade de que a soma } \\
\text { das faces voltadas para cima em seus dados seja igual a } \\
\text { 6? }\end{array}$ & $\begin{array}{l}\text { Analisar a compreensão dos alunos } \\
\text { em relação ao cálculo de probabilidade } \\
\text { na abordagem clássica (comparar com } \\
\text { a Questão 6 do Questionário inicial). }\end{array}$ \\
\hline $\begin{array}{l}\text { 4) Foi realizado um levantamento estatístico com crianças } \\
\text { do Ensino Médio de uma escola a respeito do interesse na }\end{array}$ & $\begin{array}{l}\text { Analisar a compreensão dos alunos } \\
\text { em relação ao cálculo de probabilidade } \\
\text { na abordagem clássica em uma }\end{array}$ \\
\hline
\end{tabular}


realização de um show de talentos no horário do intervalo. Os resultados foram organizados na tabela abaixo.

\begin{tabular}{|c|c|c|c|}
\hline \multirow{2}{*}{ Série } & \multicolumn{2}{|c|}{ Interesse } & \multirow{2}{*}{ Total } \\
\cline { 2 - 3 } & Sim & Não & \\
\hline $\mathbf{1}^{\text {a }}$ série & 10 & 30 & 40 \\
\hline $\mathbf{2}^{\mathbf{a}}$ série & 20 & 20 & 40 \\
\hline $\mathbf{3}^{\text {a }}$ série & 20 & 0 & 20 \\
\hline
\end{tabular}

Sorteando uma pessoa ao acaso e sabendo que ela tem interesse na realização do show, qual é a probabilidade de ela ser da $3^{a}$ série do Ensino Médio?

5) De 1 a 10, avalie o quanto você gostou de ter participado desse projeto.

Considere 1 como "não gostei nada" e 10 como "gostei muito".

6) De 0 a 10, avalie o quanto você evoluiu em relação aos conceitos de probabilidade após as discussões e reflexões do projeto.

Considere 1 como "não evoluí nada" e 10 como "evoluí muito".

7) Escolha uma palavra que represente seu percurso ao longo de todas as etapas desse projeto. situação problema que envolve a leitura de uma tabela (comparar com a Questão 8 do Questionário inicial).

Avaliar as impressões finais em relação à participação no projeto.

Avaliar as impressões finais em relação às aprendizagens no projeto.

Caso haja interesse em analisar o formato e disposição como essas questões foram apresentadas aos alunos, pode-se acessar os questionários nos anexos dessa dissertação.

\subsection{Aplicação}

A presente seção da dissertação tem como objetivo apresentar o desenvolvimento da aplicação. Desta forma, serão destacadas as alterações que ocorreram em relação ao planejamento e serão apresentados alguns quadros que ilustram a distribuição das aulas ao longo do período da aplicação da proposta de trabalho.

Visando contextualizar o grupo de alunos em relação às investigações conceituais realizadas, os estudos pré aplicação, realizados sem a presença e 
mediação do pesquisador, serão apresentados inicialmente. É importante esclarecer que o Subitem 4.4.1. foi produzido a partir de diálogos com a professora responsável pelas turmas em questão, devido à ausência do pesquisador como observador nessas aulas.

\subsubsection{Estudos pré-aplicação}

A disciplina de Matemática do $9^{\circ}$ ano do Colégio São Domingos no ano de 2019 iniciou os estudos com investigações a respeito de questões relacionadas ao acaso, aleatoriedade e a possibilidade de se realizar previsões para eventos futuros. No desenvolvimento das aulas, a professora optou por realizar atividades que partissem de perguntas que proporcionassem reflexão por parte dos alunos, leituras que despertassem a curiosidade e embasassem as discussões e atividades lúdicas nas quais os estudantes eram desafiados a realizar análises e previsões. Além disso, foram reservados momentos de exposição de conceitos matemáticos que sistematizassem o processo de aprendizagem vivido pelos alunos e situações práticas que demandassem aplicação dos conceitos apreendidos. Os próximos parágrafos são destinados a uma descrição mais detalhada dos estudos que antecederam a intervenção realizada nesta dissertação.

Como forma de despertar a curiosidade e iniciar as pesquisas sobre acaso e aleatoriedade, a professora apresentou aos alunos um livro que abordava grandes perguntas da humanidade. Ao selecionar alguns trechos do livro e indicar como leitura obrigatória para casa, a professora lança mão de uma primeira grande questão aos alunos: "é possível prever/moldar o futuro?".

Segundo relatos da professora, as considerações apresentadas pelos estudantes frente a esse questionamento foram um excelente ponto de partida para discussões reflexivas relacionadas a acontecimentos supostamente passíveis de previsões ou acontecimentos completamente imprevisíveis. Foi apontado pelos alunos que em algumas situações há a presença da imprevisibilidade, mas é possível afirmar que há mais probabilidade de algum evento se desenvolver de uma maneira do que de outra.

Após a discussão gerada pelas respostas e colocações dos alunos, o tema continuou a ser trabalhado com uma nova leitura e uma atividade prática. Dessa vez, 
baseados em uma breve descrição apresentada sobre a vida de uma determinada personagem, os alunos deveriam classificar algumas afirmações numa escala de 1 a 8, de modo que 1 fosse a mais improvável e 8 a mais provável.

As duas aulas seguintes foram destinadas a investigações lúdicas utilizando um brinquedo muito popular na década de 80 , que busca estimular a memorização de cores e sons. $O$ jogo consiste em memorizar uma sequência de cores apresentada e reproduzir com exatidão. As sequências apresentadas pela máquina sempre são idênticas à anterior, exceto pela adição de uma última cor supostamente aleatória. A partir de perguntas sobre a previsibilidade das novas aquisições das sequências, a professora introduziu conceitos iniciais de amostra, experimento aleatório e inferência estatística.

Após essas duas aulas, a professora optou por realizar a sistematização dos conhecimentos matemáticos desenvolvidos em uma aula expositiva. Até o determinado momento, os alunos já haviam construindo as primeiras ideias relacionadas ao tema, mas não eram capazes de quantificar probabilidades de eventos. Os conceitos formais e a abordagem clássica de probabilidade surgiram para os alunos durante a exposição docente desta aula. Foram apresentadas pela professora as definições de espaço amostral, evento de interesse, cálculo de probabilidade a partir da razão entre evento e espaço amostral, entre outras. Ao término da aula, foi encaminhada para os alunos uma lista de exercícios com questões em que os conceitos desenvolvidos seriam utilizados.

Após a aula de correções das questões da lista de exercícios, foi encaminhada uma discussão sobre o Paradoxo de Monty Hall, apresentado em um concurso televisivo dos Estados Unidos na década de 70. O apresentador do concurso exibia três portas, garantia que havia um prêmio em uma delas e desafiava um participante a acertar a porta premiada. Assim que o jogador elegia a porta, o apresentador abria uma das outras duas (que não era a premiada) e perguntava se havia interesse em mudar de porta ou manter o palpite inicial. Segundo a professora, os alunos apresentaram bastante interesse na discussão do problema apresentado, mas muitos estudantes não saíram da aula convencidos de que a escolha pela mudança de porta no segundo momento do concurso potencializava a probabilidade do jogador de conquistar o prêmio.

A última aula que precedeu a intervenção foi destinada a mais uma investigação: a análise do Triângulo de Pascal. Desafiados a constatar regularidades 
sobre os elementos numéricos pertencentes a representação, os alunos foram apresentados, de maneira superficial e introdutória, a questões como número binomial, permutação, arranjo e combinação.

\subsubsection{Desenvolvimento da aplicação}

O primeiro ajuste em relação ao planejamento da proposta foi a realização da apresentação inicial utilizando a totalidade do tempo da primeira aula. A escolha se deu em função do interesse em apresentar não só os aspectos referentes ao trabalho com criação de vídeos que seriam desenvolvidos nas próximas aulas, como pormenores ligados ao trabalho acadêmico de pós-graduação. Foram exibidas, em linhas gerais, as etapas relacionadas à pesquisa de mestrado e às intenções do pesquisador na proposição da sequência didática que seria apresentada a seguir. Devido ao ajuste de duração deste momento de apresentação, houve uma pequena sobra de tempo nas três turmas e realizou-se uma dinâmica de sondagem das expectativas dos alunos após o conhecimento da proposta de trabalho. A atividade escolhida foi a nuvem de palavras, que será apresentada no Subitem 5.1.

Dada esta primeira adaptação no planejamento, a aplicação do questionário ficou destinada à segunda aula e ocupou todo o tempo deste encontro. A divisão dos grupos de trabalho, a apresentação de uma recomendação do processo de criação de roteiro e o início da elaboração do mesmo, ocorreram durante a terceira aula do projeto.

Como os estudantes precisavam de mais tempo para amadurecerem as ideias centrais e pesquisarem tópicos auxiliares para suas produções, a quarta aula ocorreu com um intervalo de duas semanas após a terceira aula. Além disso, em algumas aulas fora do projeto, ministradas pela professora da turma, foram destinados pequenos momentos para que o grupo pudesse se reunir e avançar na criação do roteiro. Os estudantes também foram incentivados a organizar reuniões fora do horário de aulas para essa atividade.

Esta quarta aula do planejamento possuía como objetivo a finalização e entrega do roteiro. No entanto, foi realizada uma apresentação das ideias de roteiro desenvolvidas pelos alunos até aquele momento. Esta alteração no plano de aulas foi uma demanda dos estudantes, que alegavam não ter concluído a atividade proposta 
e solicitaram um auxílio dos colegas, da professora e do pesquisador para finalizá-la. Os grupos que, após todas as críticas e comentários, necessitassem maior suporte, poderiam utilizar o plantão do período vespertino para dialogar com o pesquisador. A entrega final dos roteiros para a professora ficou agendada para a aula da semana seguinte. Deste modo, os alunos puderam destinar tempo e energia para colocar no papel o resultado das interações com professora, pesquisador e colegas.

Novamente, houve um grande intervalo entre aulas. Desta vez, o período era destinado às gravações e edições. O suporte do pesquisador para os alunos foi apenas via e-mail ou no segundo plantão de contraturno do projeto. A professora, por sua vez, também destinou pequenos momentos de suas aulas para que os grupos pudessem se reunir. De maneira similar à confecção dos roteiros, a grande parte dos encontros destinados à criação e edição dos vídeos deu-se pela organização dos estudantes em momentos fora do horário de aulas.

A entrega das produções foi agendada para dois dias antes da apresentação dos vídeos. Assim, o pesquisador e a professora poderiam analisá-los previamente e elencar os principais tópicos a serem discutidos com a turma após a apresentação de cada produção.

Embora tenham sido organizados de quatro a cinco grupos por classe e os vídeos tenham apresentado duração de cerca de três minutos, foram destinadas duas aulas para a apresentação. Deste modo, as análises das produções e as posteriores discussões ocorreram com bastante tempo. Após cada exibição de vídeo, professora e o pesquisador foram levantando questionamentos e colocando pontos a serem revistos e aprimorados. Ao longo dessa discussão, além dos aspectos mais técnicos do vídeo, foram abordadas e esclarecidas questões conceituais importantes. Além disso, neste momento de discussão, houve a inclusão de uma atividade de avaliação e análise dos alunos em relação aos trabalhos dos colegas e aos próprios vídeos.

Estava presente no planejamento a realização de uma apresentação final de segundas versões dos vídeos, que aconteceria após uma reavaliação e reelaboração pelos integrantes dos grupos. No entanto, o pesquisador e a professora decidiram conjuntamente não mencionar essa etapa no momento da apresentação inicial das etapas do projeto. A decisão foi tomada considerando dois aspectos. O primeiro deles era a incerteza em relação à quantidade de aulas que a professora poderia destinar ao projeto e o segundo era a expectativa de que essa demanda aparecesse de maneira espontânea pelos alunos. 
Essa demanda apareceu logo após o momento de avaliação, no qual os alunos perceberam a grande quantidade de aspectos que deveriam ser repensados em suas produções. Em todas as turmas, eles trouxeram à tona essa necessidade de refazer e reestruturar o vídeo. Como notou-se viável destinar mais um momento para o projeto, realizou-se, então, essa etapa de trabalho.

Os alunos tiveram mais uma semana e meia para elaborar, em momentos fora do período letivo, uma segunda versão. Diferente dos demais encontros, esta apresentação final da última etapa, denominada Festival, ocorreu logo após o período de aulas de uma sexta-feira. Os vídeos deveriam ser enviados por e-mail até a terçafeira para que os jurados pudessem avaliá-los. A banca de júri foi composta pela professora, pelo pesquisador e por mais quatro convidados: o coordenador geral do Ensino Médio, a professora de Português dos nonos anos, a auxiliar de coordenação do Ensino Fundamental e o funcionário responsável pelo almoxarifado da escola.

Os seis membros dessa banca avaliadora assistiram aos vídeos finais dos alunos e, com auxílio de um formulário eletrônico, avaliaram as produções em seis critérios. Os critérios utilizados para a avaliação das produções foram: (1) Conteúdo conceitual - Imprecisões; (2) Conteúdo conceitual - Clareza; (3) Criatividade; (4) Enredo; (5) Qualidade técnica - Áudio; e (6) Qualidade técnica - Recursos de edição. Ao final da avaliação, os jurados ainda forneceram uma nota geral para cada produção que variava de 0 a 4 .

A tabela abaixo apresenta uma comparação entre as aulas que estavam planejadas e as aulas que foram efetivamente desenvolvidas e apresentadas neste capítulo.

Quadro 14 - Descrição das aulas

\begin{tabular}{|l|l|l|}
\hline & \multicolumn{1}{|c|}{ Planejamento } & \multicolumn{1}{|c|}{ Projeto realizado } \\
\hline Aula 1 & $\begin{array}{l}\text { Apresentação do pesquisador e da } \\
\text { proposta do projeto. } \\
\text { Questionário de sondagem }\end{array}$ & $\begin{array}{l}\text { Apresentação o pesquisador, da } \\
\text { pesquisa e da proposta do projeto. }\end{array}$ \\
\hline Aula 2 & $\begin{array}{l}\text { Separação em grupos de trabalho } \\
\text { Levantamento de ideias para } \\
\text { construção do roteiro } \\
\text { Apresentação das ideias para a sala }\end{array}$ & Questionário de sondagem \\
\hline Aula 3 & Escrita do roteiro & $\begin{array}{l}\text { Separação em grupos de trabalho } \\
\text { Início da construção do roteiro }\end{array}$ \\
\hline
\end{tabular}




\begin{tabular}{|l|l|l|}
\hline Aula 4 & Escrita do roteiro & Apresentação e análise dos roteiros \\
\hline Aulas 5 e 6 & $\begin{array}{l}\text { Apresentação e discussão das } \\
\text { produções dos alunos } \\
\text { Indicações de aspectos relevantes } \\
\text { para a reelaboração do vídeo }\end{array}$ & $\begin{array}{l}\text { Apresentação e discussão das } \\
\text { produções dos alunos } \\
\text { Indicações de aspectos relevantes } \\
\text { para a reelaboração do vídeo }\end{array}$ \\
\hline Aula 7 & Questionário final & $\begin{array}{l}\text { Apresentação final dos vídeos } \\
\text { produzidos - Festival }\end{array}$ \\
\hline Aula 8 & $\begin{array}{l}\text { Apresentação final dos vídeos } \\
\text { produzidos }\end{array}$ & Questionário final \\
\hline
\end{tabular}

O cronograma abaixo apresenta a distribuição de aulas de uma das três turmas. Pode-se analisar a distribuição desses encontros ao longo dos meses de março, abril e maio do ano de 2019. Em dois momentos, é possível notar a ocorrência de plantões de dúvidas. Esses momentos aconteceram no contraturno e os estudantes interessados poderiam encontrar o pesquisador e a professora para esclarecer dúvidas ou solicitar algum eventual suporte. 
Quadro 15 - Cronograma - 9a ano B

\begin{tabular}{|c|c|c|c|c|}
\hline Segunda & Terça & Quarta & Quinta & Sexta \\
\hline $25 / 03$ & $26 / 03$ & $27 / 03$ & $\begin{array}{c}\text { 28/03 - } 2 \text { aulas } \\
\text { Introdução } \\
\text { Questionários }\end{array}$ & $\begin{array}{l}\text { 29/03 - } 1 \text { aula } \\
\text { Início Roteiro }\end{array}$ \\
\hline 01/04 & $02 / 04$ & $03 / 04$ & $04 / 04$ & 05/04 \\
\hline 08/04 & $09 / 04$ & $10 / 04$ & $11 / 04$ & $\begin{array}{c}\text { 12/04 - } 1 \text { aula } \\
\text { Roteiro } \\
\text { Plantão } 1\end{array}$ \\
\hline $15 / 04$ & $\begin{array}{l}\text { 16/04 } \\
\text { Entrega dos } \\
\text { roteiros }\end{array}$ & $17 / 04$ & $18 / 04$ & $\begin{array}{l}\text { 19/04 } \\
\text { FERIADO }\end{array}$ \\
\hline $22 / 04$ & $23 / 04$ & $24 / 04$ & $25 / 04$ & $\begin{array}{l}\text { 26/04 } \\
\quad \text { Plantão } 2\end{array}$ \\
\hline $29 / 04$ & $\begin{array}{l}30 / 04 \\
\text { Entrega 1a versão }\end{array}$ & $\begin{array}{l}\text { 01/05 } \\
\text { FERIADO }\end{array}$ & $\begin{array}{l}\text { 02/05 - } \mathbf{1} \text { aula } \\
\text { Apresentações }\end{array}$ & $\begin{array}{l}\text { 03/05 - } 1 \text { aula } \\
\text { Apresentações }\end{array}$ \\
\hline 06/05 & $07 / 05$ & $08 / 05$ & 09/05 & $10 / 05$ \\
\hline $13 / 05$ & $\begin{array}{l}\text { 14/05 } \\
\text { Entrega versão } \\
\quad \text { final }\end{array}$ & $15 / 05$ & $16 / 05$ & $\begin{array}{c}17 / 05 \text { - } 2 \text { aulas } \\
\text { Festival }\end{array}$ \\
\hline
\end{tabular}




\section{Análise da aplicação}

\subsection{Impressões iniciais}

Ao dedicar um tempo maior para apresentação inicial, foi possível dar um passo importante no estabelecimento de uma relação de proximidade e colaboração com os alunos. Era importante deixar claro para os estudantes que o foco da pesquisa ia além do produto final, mas consideraria o percurso total, que seria inteiramente analisado. Desta maneira, os alunos puderam compreender que não seriam avaliados em relação aos conhecimentos e atividades que haviam realizado anteriormente à aplicação do projeto. $O$ alvo da investigação era o processo percorrido por eles durante todos aqueles encontros. Com isso, ficaram mais à vontade para expor o que de fato estavam compreendendo até o momento e verbalizar novos desdobramentos e descobertas.

O comportamento das três turmas diante da apresentação inicial não foi uniforme. Enquanto pôde-se perceber uma das salas bastante atenta, aparentemente motivada, mas pouco participativa, as outras duas turmas mostraram uma interação maior com o pesquisador, expondo dúvidas e articulando ideias de forma a deixar clara a entusiasmo diante da proposta de trabalho que estava sendo exibida. Desde o primeiro momento, os estudantes mostraram-se, em geral, muito receptivos e agradáveis com o pesquisador, o que favoreceu a formação de vínculo importante para o trabalho entre as duas partes.

A dinâmica da nuvem de palavras foi uma atividade cujo objetivo era traçar um panorama geral das sensações dos alunos ao final da primeira aula com o pesquisador. Cientes das etapas de trabalho que teriam pela frente, os alunos utilizaram uma modalidade de atividade disponível no site mentimeter.com, preparada previamente, para completar a frase: "Após conhecer a proposta de trabalho, eu me sinto...". Esta ferramenta organiza as palavras digitadas pelos alunos de forma a deixar, gradualmente, o tamanho das palavras de acordo com a sua ocorrência: quanto maior for a ocorrência, maior será o tamanho. A imagem a seguir ilustra um dos resultados da atividade descrita. É importante esclarecer que houve preocupação em manter as redações dos alunos tal qual foram digitadas. 


\section{Após conhecer a proposta do projeto, eu me sinto...}

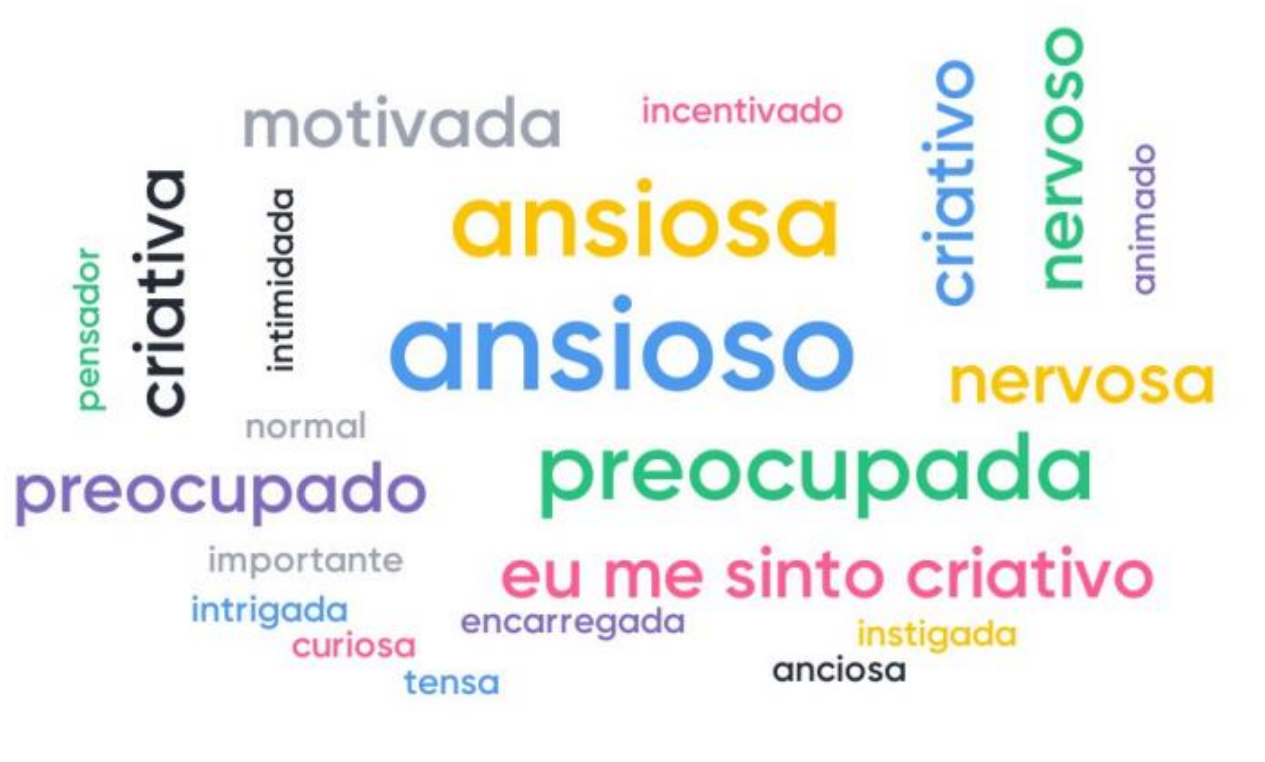

Pode-se analisar que os alunos se sentiram bastante ansiosos ao receber as informações referentes à proposta de atividade e suas etapas. Sentimentos e sensações como ansiedade, preocupação e nervosismo costumam despontar quando as atividades diferem da lógica da aula tradicional. Evidentemente, as relações características de um trabalho colaborativo e a exposição da imagem em uma produção audiovisual devem ter colaborado para que os alunos completassem a afirmação com palavras que carregam um certo sentimento de apreensão. No entanto, foi possível perceber pela nuvem de palavras, que alguns estudantes estavam se sentindo intrigados, curiosos e incentivados. Palavras relacionadas com criatividade tiveram bastante incidência na dinâmica realizada.

\subsection{Questionário inicial}

Mesmo cientes de que não era uma avaliação individual formal, que o alvo de investigação era o contexto geral da sala, o cenário da segunda aula era de um grupo de alunos apreensivos na realização do Questionário inicial. Era visível que havia muito interesse em mostrar os conhecimentos sistematizados nos estudos anteriores à aplicação e um grande receio de revelar fragilidades no assunto. Os alunos 
responderam às dez questões propostas de maneira individual e sem consulta às suas anotações e seu material. De maneira geral, mostraram que possuíam familiaridade com aspectos relacionados aos experimentos aleatórios e situações em que há a presença de uma análise probabilística.

A análise das respostas dos alunos no Questionário inicial auxiliou no planejamento das futuras discussões, indicando pontos de partida importantes nos diálogos com os estudantes, tanto nos momentos de mediação para a produção do roteiro, quanto nas análises das produções dos vídeos.

O quadro abaixo apresenta algumas respostas obtidas na primeira questão, que indagava a respeito de qual era a probabilidade de uma moeda lançada cair com a face "cara" voltada para cima.

Quadro 16 - Respostas de alunos na primeira questão do Questionário inicial

1) Ao lançar uma moeda de cinquenta centavos qualquer, qual é a probabilidade de ela cair com a face "cara" voltada para cima? Justifique.
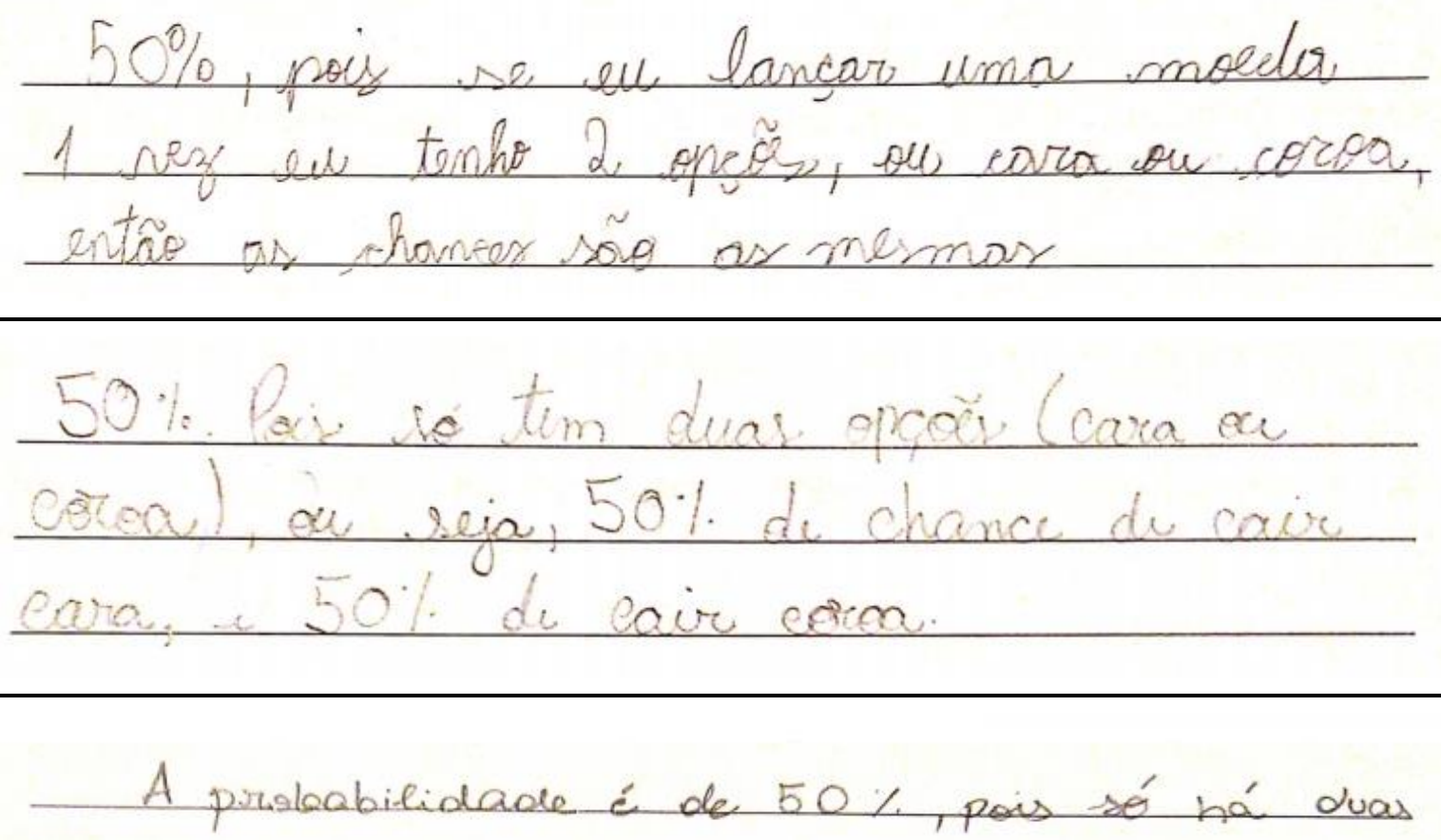

Pousibifidrudes de reswltadr i ov cara a cona

As três respostas acima representam a maioria dos textos produzidos pelos alunos neste primeiro item do questionário. Pode-se perceber que não há preocupação dos alunos em mencionar o equilíbrio (honestidade) da moeda. 
Conceitualmente, este cuidado é relacionado com um aspecto importante da análise probabilística, na abordagem laplaciana, que é a necessidade da equiprobabilidade do espaço amostral, como apontou Batanero (2005).

Embora nenhum aluno tenha apresentado uma resposta que destacasse a necessidade de garantia do equilíbrio da moeda, foi notório que os estudantes identificaram nesta primeira questão que a probabilidade de uma moeda, ao ser lançada, cair com a face "cara" voltada para cima é de 50\%. O gráfico abaixo apresenta o desempenho dos alunos nesta primeira questão.

Figura 3 - Gráfico de desempenho da primeira questão do Questionário inicial

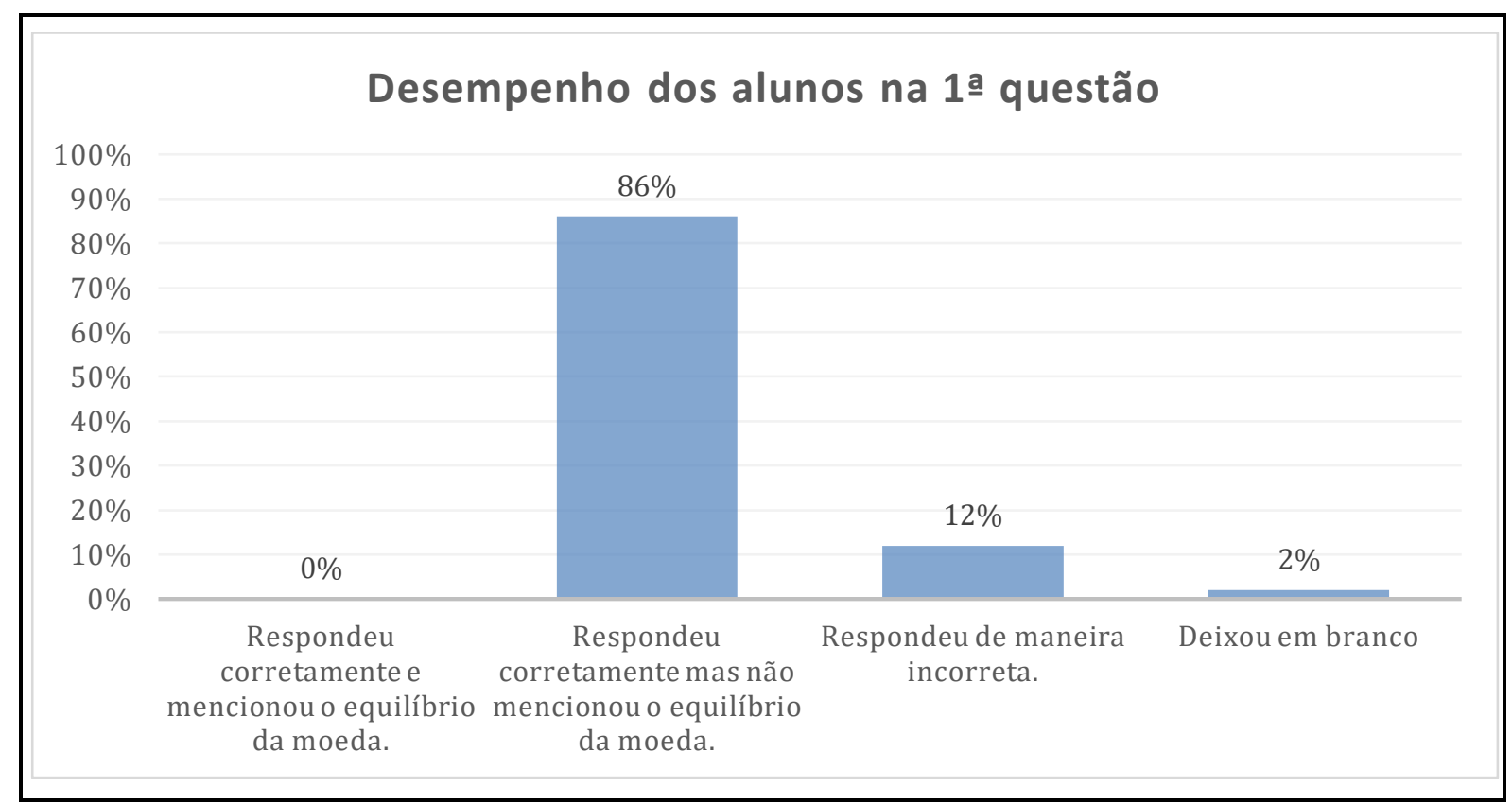

Nota-se que é expressivo o número de alunos que atribuiu um valor adequado para a probabilidade solicitada. Foram 56 dos 65 alunos que não mencionaram equilíbrio, mas responderam $50 \%$.

A segunda questão foi elaborada visando analisar a concepção dos estudantes a respeito de adoção de eventuais hipóteses para atribuição de probabilidade. No entanto, como as respostas abertas apresentaram-se de forma muito ampla e pouco se relacionaram com aspectos desejados na pesquisa, a análise das respostas foi suprimida, nos levando assim, diretamente para a próxima questão.

As respostas obtidas na terceira questão, por sua vez, apresentam uma boa articulação das ideias relacionadas aos experimentos aleatórios, como a independência de experimentos. Ao serem questionados sobre a concordância ou 
não em relação à afirmação de que no sexto lançamento de uma moeda equilibrada que sucede cinco situações em que a face "coroa" apareceu voltada para cima, a probabilidade de se obter "cara" é maior que $50 \%$, os alunos em sua maioria discordaram, como ilustra o gráfico a seguir.

Figura 4 - Gráfico de desempenho da terceira questão do Questionário inicial

3) Após 5 lançamentos de uma moeda equilibrada, constatou-se um resultado de 5 coroas. Podemos afirmar que no próximo lançamento a probabilidade de se obter uma cara é maior do que $50 \%$ ? Justifique.

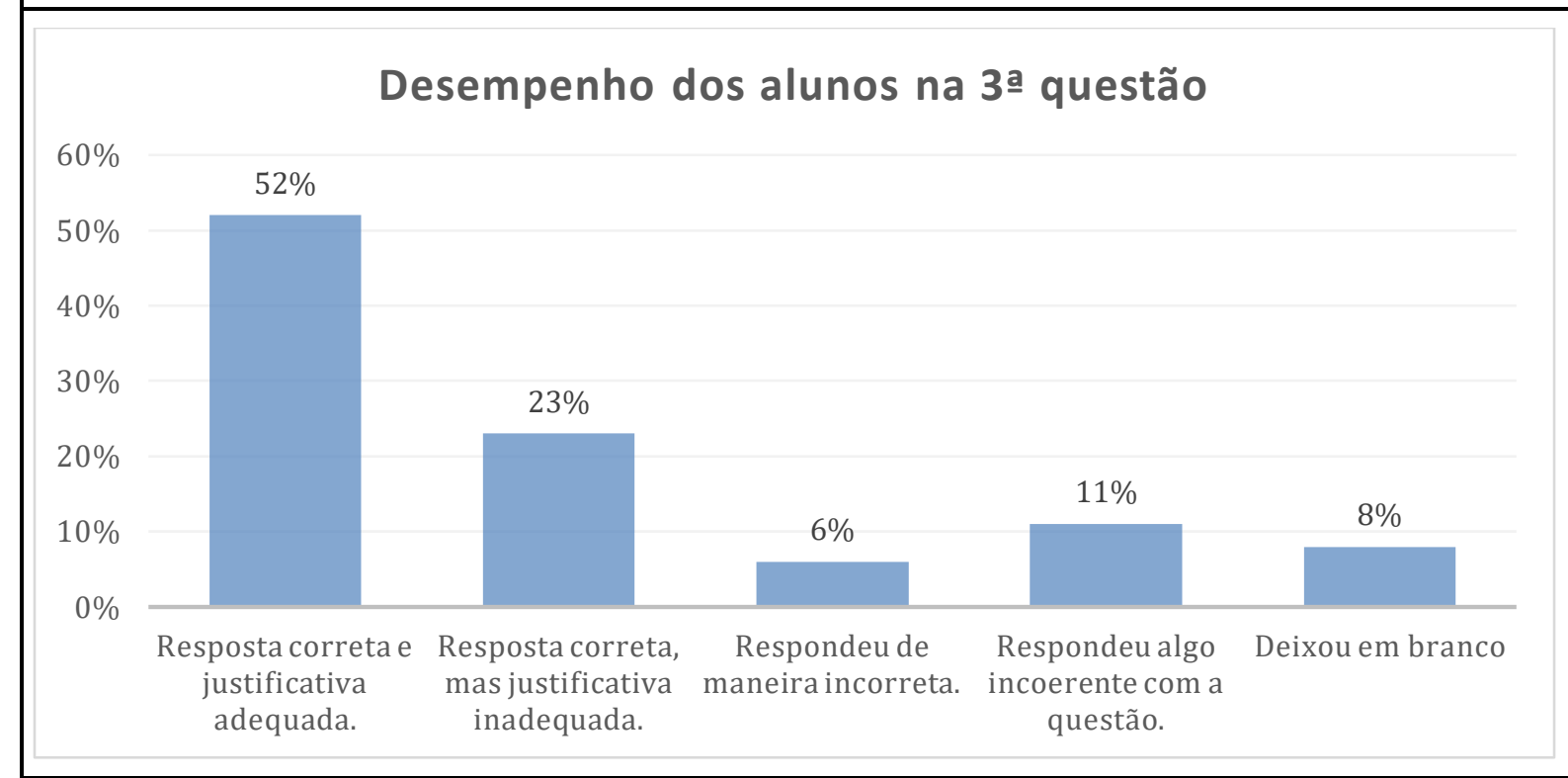

Ao todo foram 49 alunos, dentre os 65 que discordaram (apresentando justificativa adequada ou não) da afirmação e algumas das respostas que utilizaram a independência dos experimentos estão apresentadas no quadro abaixo. 


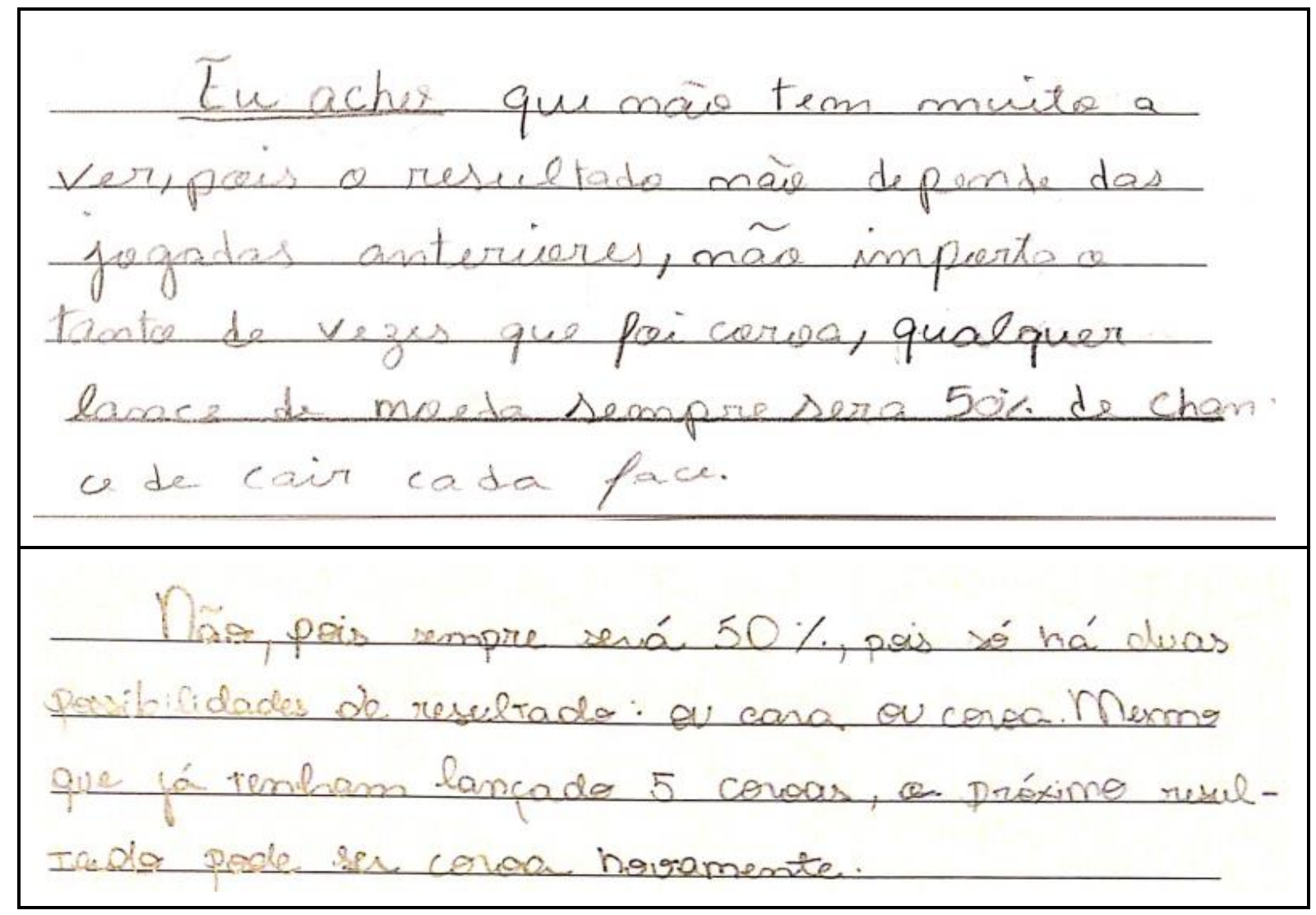

É visível nas respostas dos dois estudantes que há a clareza de que os eventos são independentes e que o histórico dos lançamentos anteriores não influencia o experimento aleatório seguinte, no qual novamente a situação é de uma moeda lançada e que estamos estudando qual a face deve cair voltada para cima. Novamente não há a cautela na análise da equiprobabilidade do espaço amostral. No entanto, esse cuidado não se fazia imprescindível uma vez que foi apresentado no enunciado que se tratava de uma moeda equilibrada.

Podem ser observados, a partir da análise das respostas dos alunos na Questão 4, indícios de uma boa compreensão do significado da atribuição de valores numéricos para quantificação de probabilidade de ocorrências e da distinção de evento impossível e evento improvável. A situação proposta era de um cidadão que optou por sair de casa com o guarda-chuva após receber informação de que a previsão do tempo garantia probabilidade de chuva de $95 \%$. Os alunos precisavam concordar ou discordar deste cidadão que, ao voltar para casa indignado por não ter caído um pingo sequer, afirma que a previsão estava errada. O quadro abaixo apresenta algumas respostas obtidas. 
Quadro 18 - Respostas de alunos na quarta questão do Questionário inicial

4) Marcos olhou o noticiário pela manhã e, ao perceber que a previsão do tempo indicava que probabilidade de chuva era de $95 \%$, saiu com seu guarda-chuva para seu dia de trabalho. Ao voltar para casa, tarde da noite, com seu guarda-chuva completamente seco, afirmou: "A previsão estava errada, pois não caiu nenhuma gota de chuva". Você concorda com Marcos? Justifique.

Nâs pois a previsais apinmow que timha $95 \%$ e nav $100 \%$, aunda timha $5 \%$ de chamces de nôu chover. Mesmo sendo bem prucas chances a molo podia acontecer de näo chroer-

hão. a pridabilidade mã í uma regra. apenas uma possibilidade do que pode acontevie. Se timera $95 \%$ de chame de chover, tinte $5 \%$ de cravee de nön hover. Ww syow, a thane de chover eva mavar, mas mao totolmente certeria.

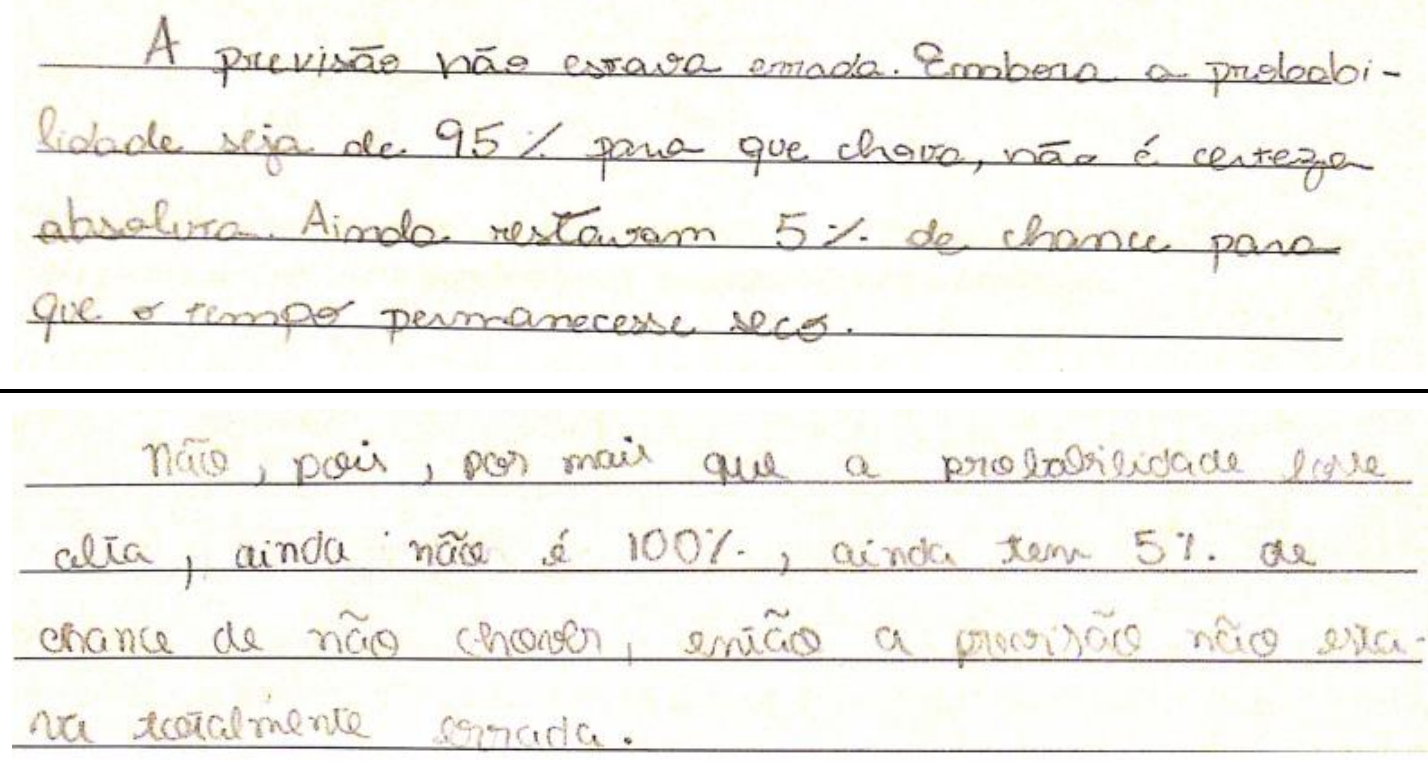

A natureza probabilística da previsão meteorológica costuma trazer confusões para a população, que sente necessidade de obtenção de uma resposta binária para a futura ocorrência de um clima chuvoso. Embora poucos alunos tenham apresentado 
conclusões que ilustram essa dificuldade de distinguir o significado da atribuição de 95\% de probabilidade de um evento ocorrer, a grande maioria conseguiu contemplar em suas respostas que se há $5 \%$ de probabilidade ocorrência, este evento é pouco provável, porém não é impossível. A última resposta apresentada no quadro acima, traz um pouco da sofisticação presente na Questão 4, pois apesar da aluna discordar com a afirmação, deixa a impressão de que a previsão ainda poderia ser considerada "um pouco" errada.

Embora essa primeira seção do questionário que continha indagações mais abertas e conceituais tenha retratado boa compreensão dos estudantes, a seção com questões mais voltadas aos cálculos, listagem de espaço amostral e leitura de tabela expuseram uma certa fragilidade das três turmas. Os gráficos abaixo apresentam 0 desempenho dos alunos nas questões 5, 6, 7 e 8 .

Figura 5 - Gráfico de desempenho na Questão 5 do Questionário inicial

5) Em três lançamentos de uma moeda equilibrada, qual é a probabilidade de se obter ao menos duas faces "cara"?

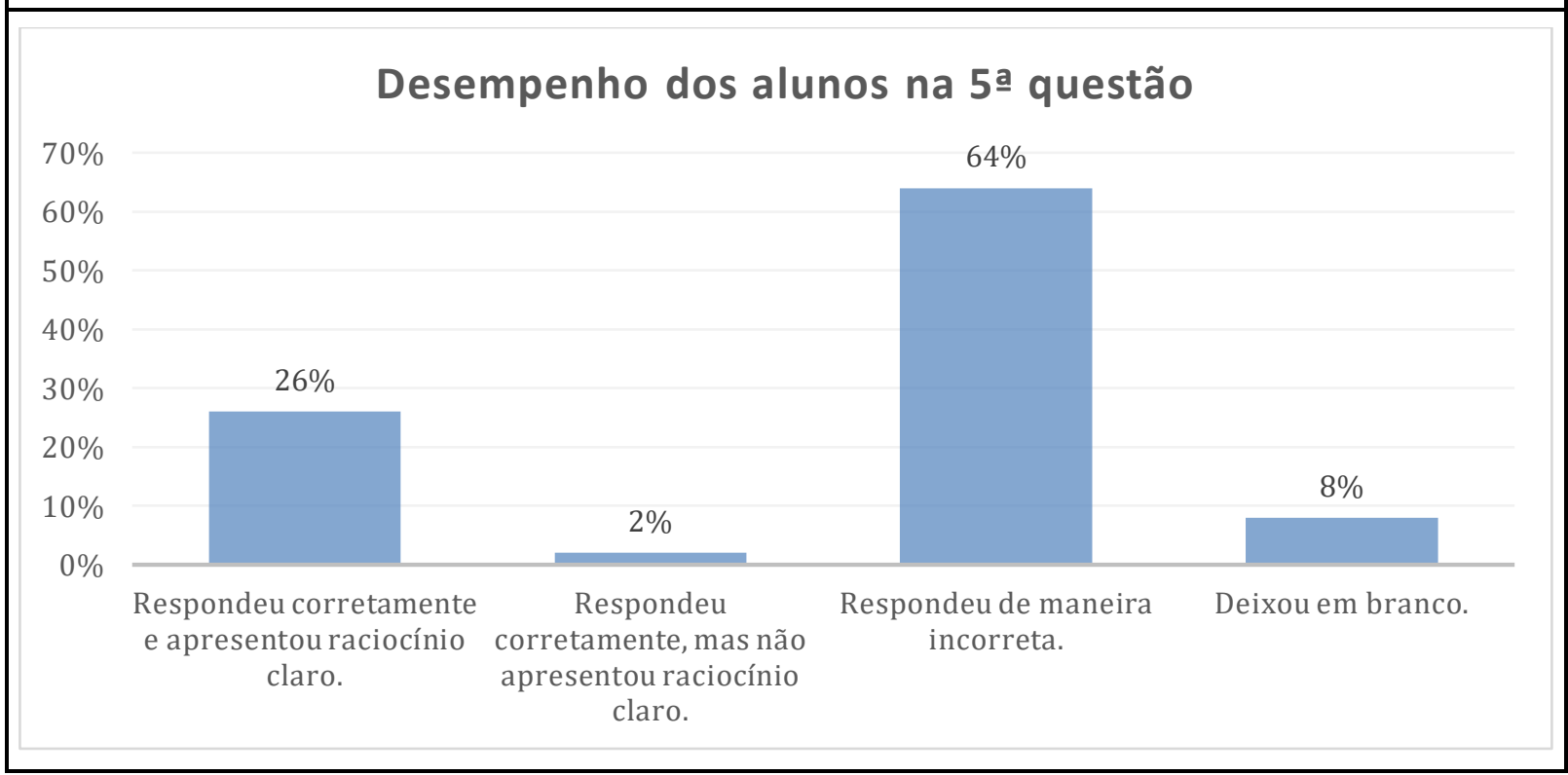


Figura 6 - Gráfico de desempenho na Questão 6 do Questionário inicial

6) José afirmou que, no lançamento de dois dados equilibrados, a probabilidade de se obter uma soma 8 juntando os valores das faces voltadas para cima é maior que a probabilidade de se obter soma 5. Você concorda? Justifique sua resposta.

\section{Desempenho dos alunos na 6a questão}

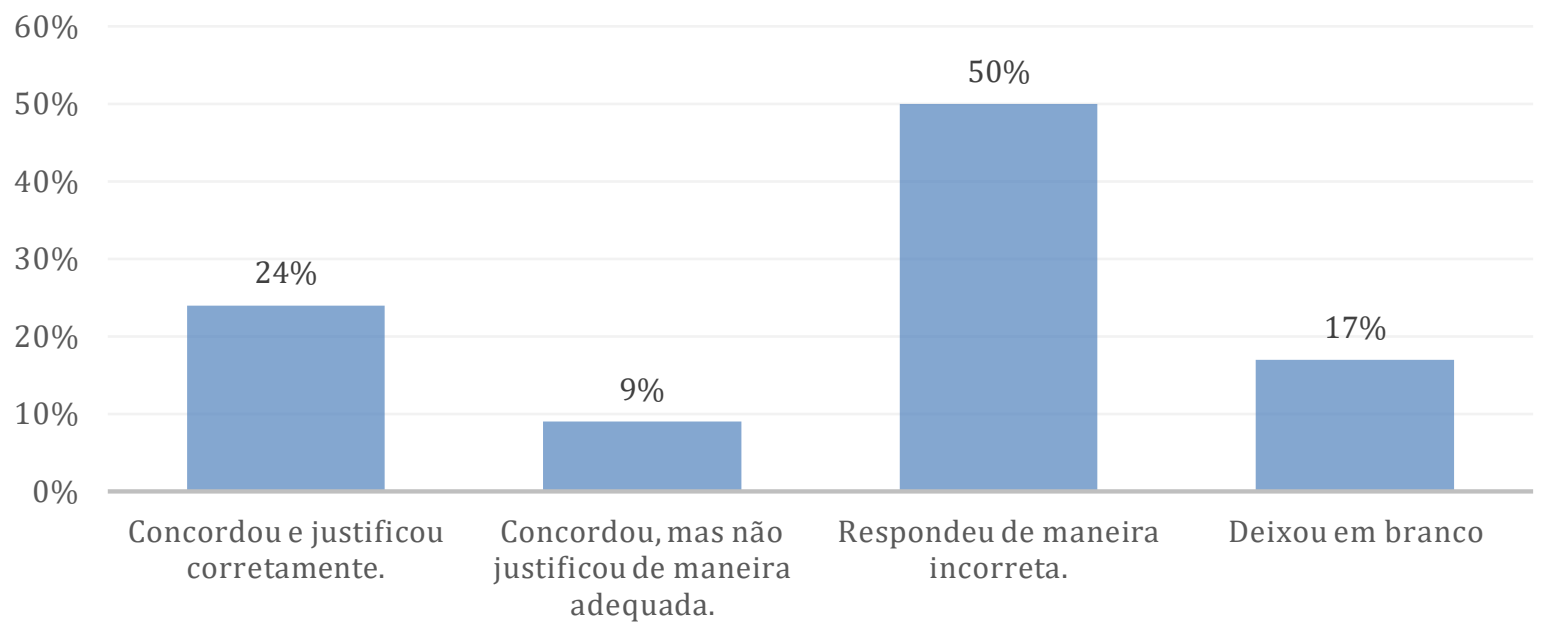

Figura 7 - Gráfico de desempenho na Questão 7 do Questionário inicial

7) Sorteando-se ao acaso um desses indivíduos (dados na tabela), calcule a probabilidade de que ele pratique exercícios regularmente e possua doença cardíaca.

\section{Desempenho dos alunos na 7ạ questão}

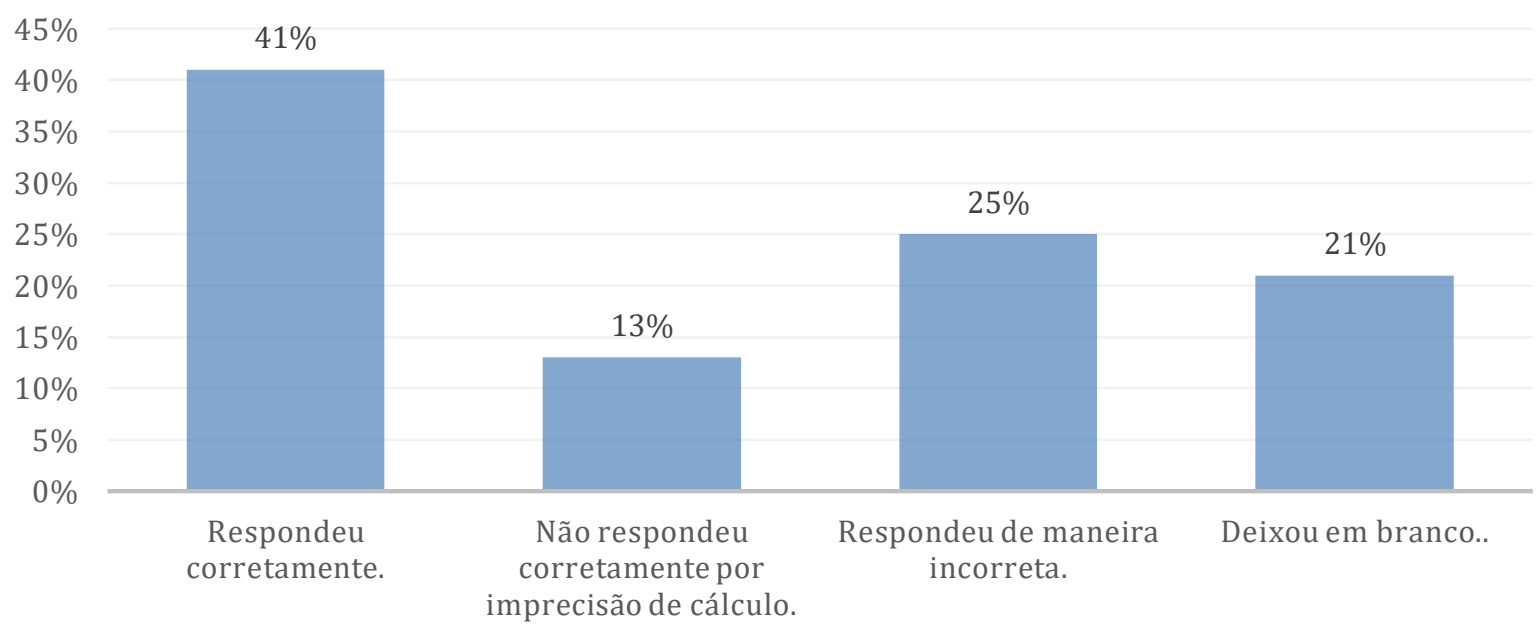


Figura 8 - Gráfico de desempenho na Questão 8 do Questionário inicial

8) Sorteando-se ao acaso um indivíduo dentre aqueles que praticam exercícios regularmente ou irregularmente (dados na tabela), calcule a probabilidade de que ele seja portador de doença cardíaca.

\section{Desempenho dos alunos na 8 a questão}

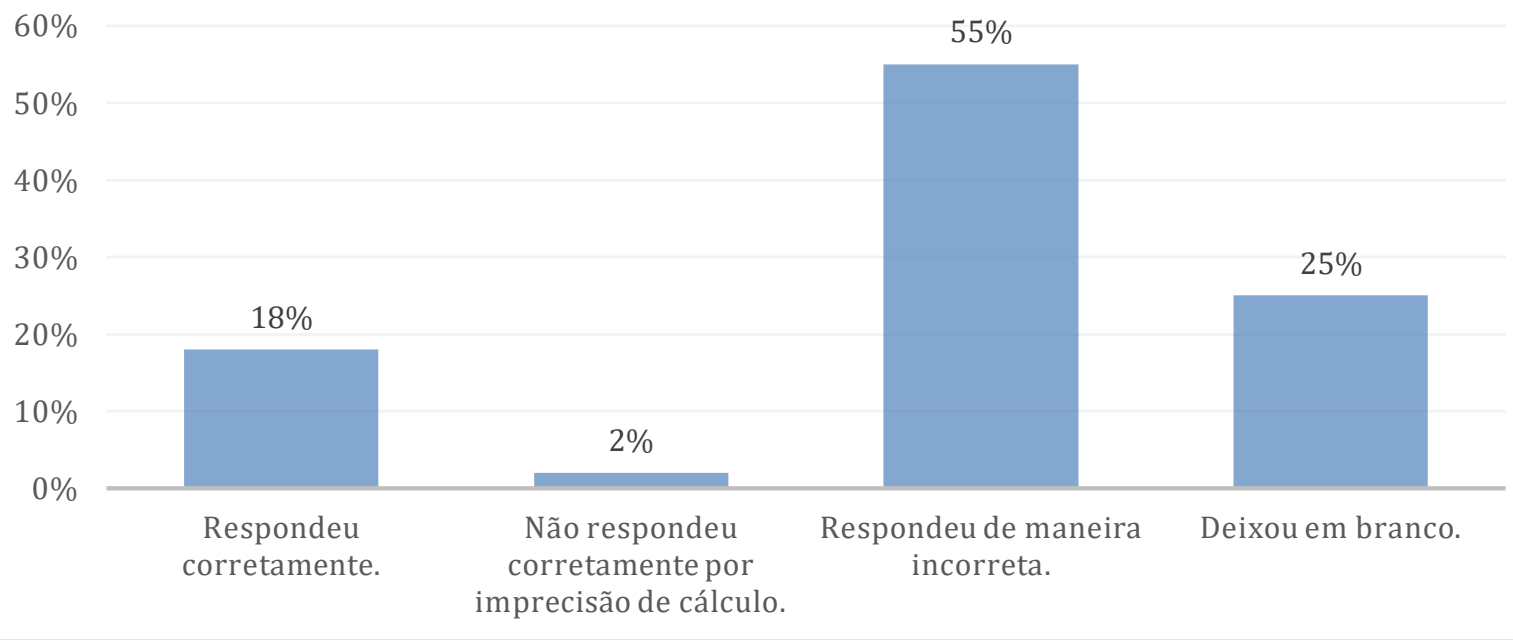

Nota-se que é muito expressivo o número que corresponde à somatória da porcentagem dos alunos que respondeu de maneira incorreta com a porcentagem que deixou em branco o espaço para resolução. Nas questões 5, 6, 7 e 8 ilustradas acima, esta somatória é respectivamente $72 \%, 67 \%, 46 \%$ e $80 \%$.

A última seção do questionário tinha como objetivo analisar o nível de motivação dos estudantes em relação à proposta apresentada e a familiaridade com criação e edição de vídeos. Na Questão 9, o aluno deveria atribuir a si mesmo uma nota de 1 a 10 em relação à sua motivação, sendo 1 "nada interessado" e 10 "extremamente interessado". 
Figura 9 - Gráfico que apresenta nível de motivação dos estudantes.

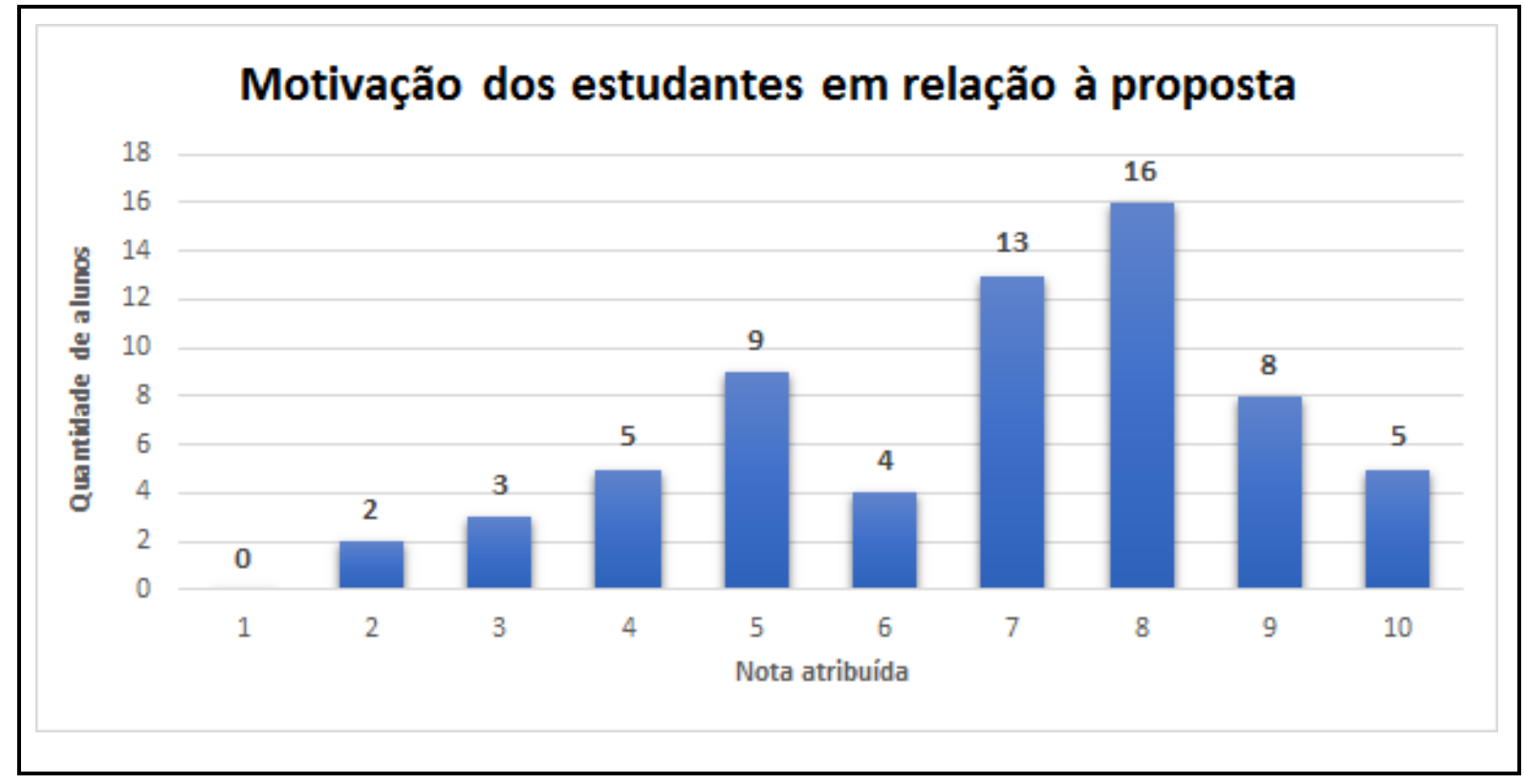

Como indicado no Capítulo 2, vemos aqui os estudantes apresentando interesse em se relacionar com aprendizagem de maneira diferente do que existia há algumas décadas. Grande parte dos alunos, aproximadamente $70 \%$, optou por assinalar um valor acima de 5 , indicando que as turmas estavam motivadas para as etapas futuras.

A familiaridade dos estudantes com questões técnicas referentes à criação e edição de vídeos pôde ser dimensionada também neste questionário. Na última questão, foi solicitado a cada aluno realizar a atribuição de uma nota de 1 a 10 que retratasse sua familiaridade com esses aspectos, sendo 1 "nenhuma familiaridade" $e$ 10 "extrema familiaridade". Notou-se que os alunos apresentam nível de contato bem variado com aspectos técnicos de criação e edição. Desta forma, foi relevante mapear essa distribuição dos alunos, na formação dos grupos de trabalho. 
Figura 10 - Gráfico que apresenta nível de familiaridade com questões técnicas

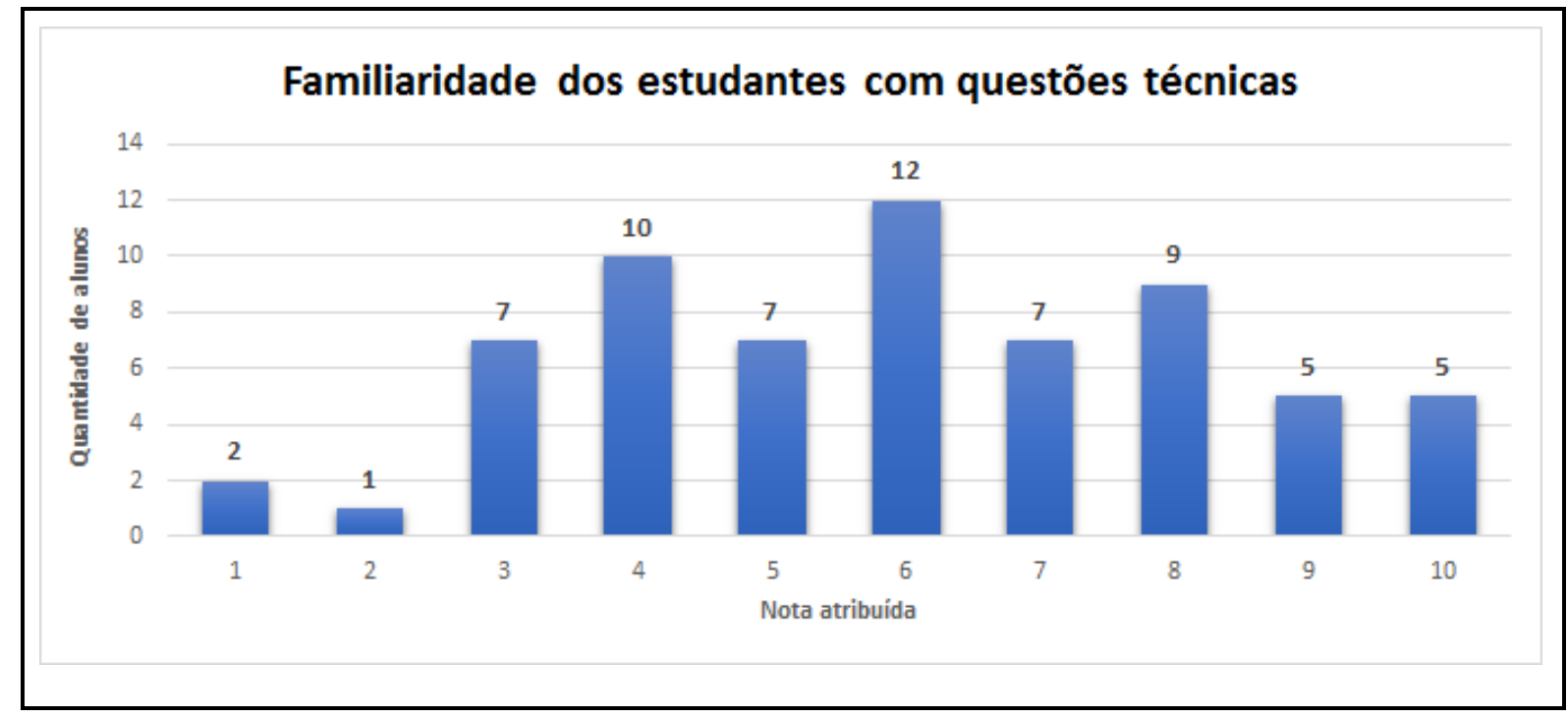

É interessante destacar que a criação do vídeo consiste em muito mais do que a filmagem e edição. Deste modo, mesmo os alunos que se atribuíram uma nota baixa conseguiram participar efetivamente da confecção do vídeo, no roteiro, na concepção das ideias e na dramatização do vídeo. No entanto, possuir ao menos um integrante com a experiência com a filmagem e edição é evidentemente um fator facilitador do processo.

\subsection{Roteiros}

A partir da terceira aula do projeto, os alunos foram orientados a confeccionar o roteiro do vídeo que seria produzido na etapa seguinte. Como forma de introduzir o significado e a importância deste instrumento, a discussão foi iniciada com uma citação de Vargas, Rocha e Freire (2007), na qual afirmam que o roteiro:

É o detalhamento de tudo o que vai acontecer no vídeo. O roteiro tem uma linguagem própria que se destina a orientar a equipe de produção nas filmagens e divide o vídeo em cenas com o objetivo de informar textualmente o leitor a respeito daquilo que o espectador verá/ouvirá no vídeo. (p.3)

Sendo assim, foi necessário realizar um levantamento dos conhecimentos prévios dos alunos a respeito desta linguagem própria e do conteúdo que deveria se fazer presente no roteiro. Após as colocações dos estudantes, foram apresentadas 
cinco perguntas norteadoras que serviriam como base para os primeiros passos na decisão do que filmar.

Figura 11 - Slide da apresentação realizada na terceira aula

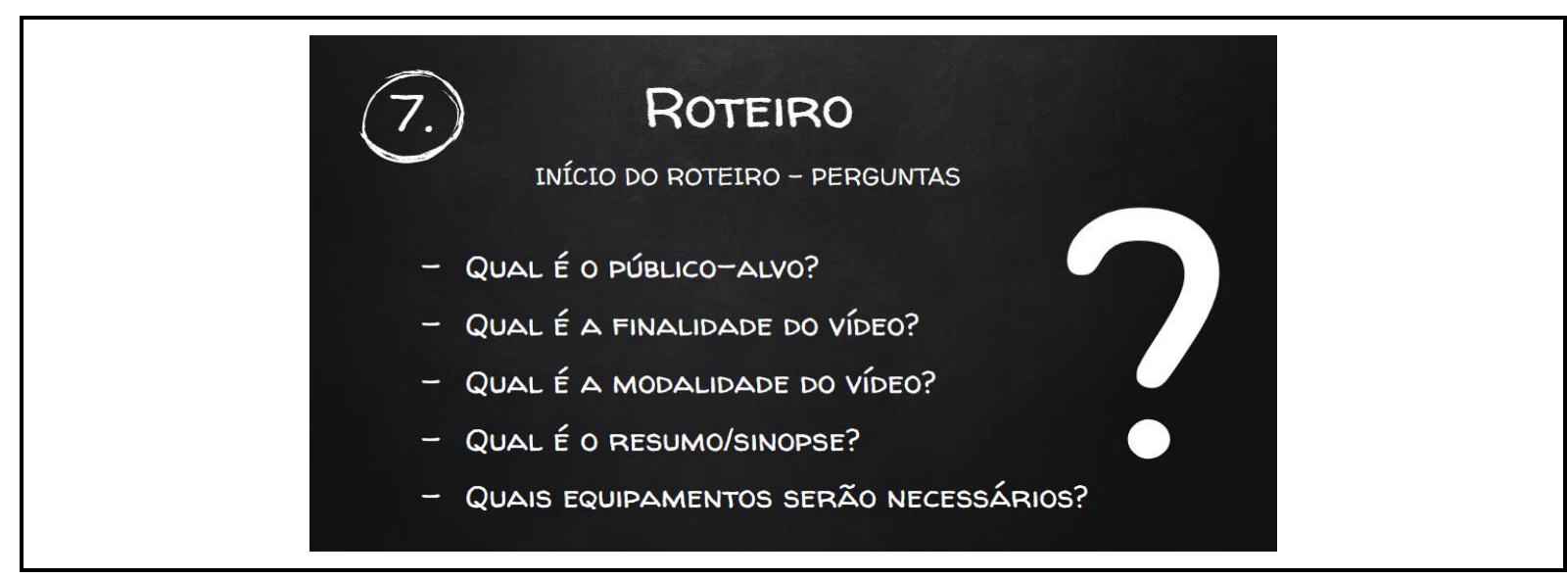

A primeira delas objetivava a determinação do público-alvo. Fez-se necessário este ponto de partida para definir a linguagem mais adequada a ser utilizada ao longo do vídeo e a profundidade acerca dos conteúdos que seriam desenvolvidos. Os grupos optaram por algumas opções de público-alvo, como alunos de anos iniciais do segundo ciclo do Ensino Fundamental, alunos de nono ano que iniciariam os seus estudos com conceitos relacionados à probabilidade, alunos que já haviam desenvolvido algum estudo neste tema e tivessem interesse em retomar ou revisitar algum tema específico ou mesmo alunos de anos mais avançados como as três séries do Ensino Médio. É importante destacar que tal decisão é fundamental para a escolha da intencionalidade didática e adequação da linguagem em um processo na qual os estudantes tomam o papel de protagonismo, como apontam Lopes e Bizerril (2018):

Ser protagonista de um processo de produção audiovisual é ter a oportunidade de perceber que escolhas são feitas e que existem interesses por parte de quem produz. $\mathrm{O}$ ato de produzir o vídeo permite que o sujeito protagonista (produtor), seja o "alguém" que faz sua escolha, que expõe por meio do instrumento tecnológico o pensamento criativo, e se coloca diante da câmera para se expressar e mostrar os seus interesses. (p.69)

As demais perguntas norteadoras encaminharam reflexões a respeito da finalidade e modalidade do vídeo, do conteúdo conceitual que seria desenvolvido e dos equipamentos necessários para as filmagens. 
Foi esclarecido que havia grande liberdade para escolha do modelo de registro do roteiro e, desta forma, os grupos receberam folhas de papel A4 em branco para organizar as informações em textos, tabelas ou quadros. No entanto, como esta confecção para muitos estudantes era uma atividade inédita, foi apresentado um modelo de roteiro de três colunas. A primeira consiste em um espaço para enumeração e breve descrição da cena, na segunda é um setor destinado à descrição do cenário, figurino, modo que a câmera captará a cena, local onde ocorrerão as gravações e demais aspectos visuais e, por fim, na terceira deve constar a descrição dos diálogos que acontecerão na cena e os demais sons (efeitos, música de fundo, narração).

Figura 12 - Slide da apresentação realizada na terceira aula

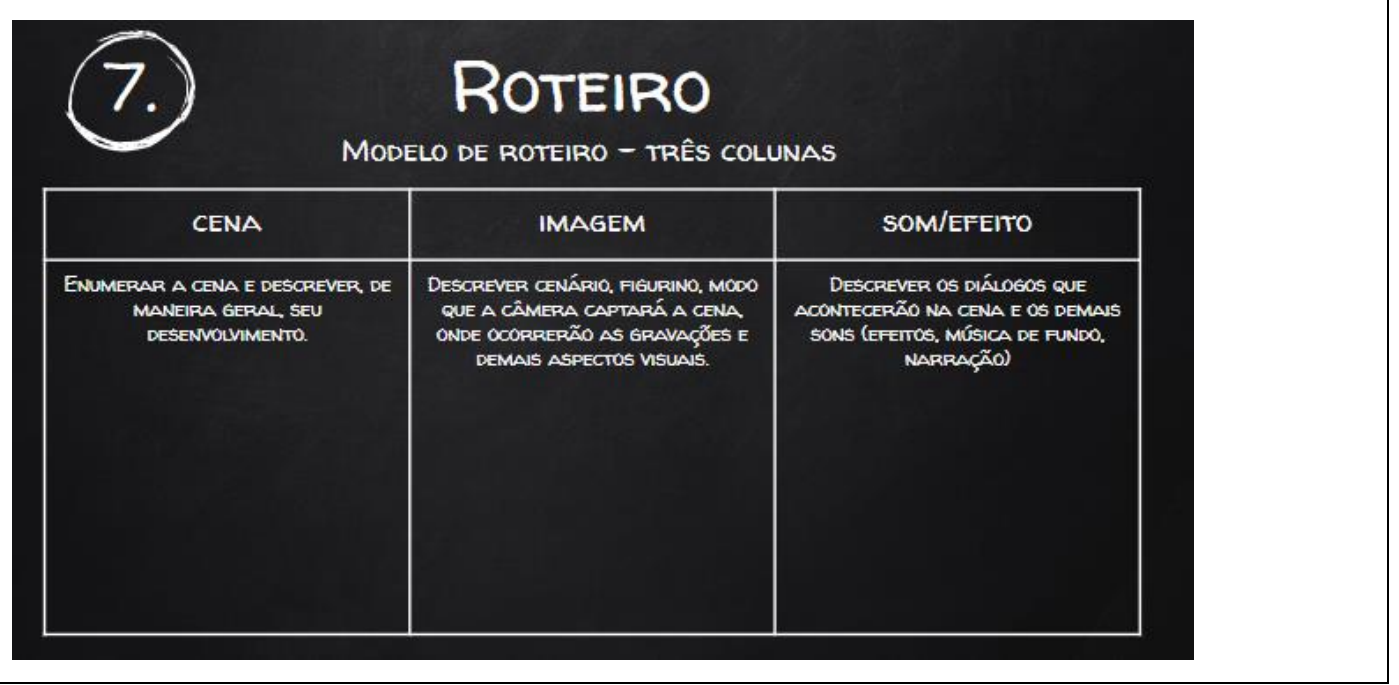

De maneira geral, os grupos optaram por responder as cinco perguntas norteadoras na primeira página do roteiro e, nas demais, listar as cenas e apresentar alguns trechos de diálogos entre personagens, narração e detalhes importantes para a posterior edição. Cerca de metade dos grupos, apresentou pouco comprometimento em relação à dedicação e empenho na roteirização do vídeo. Tal comportamento pode ser explicado pelo fato desses estudantes não terem compreendido totalmente a importância desse instrumento na criação audiovisual. Evidentemente, esse tipo de questão volta à tona ao longo das gravações e edições, pois um grupo que confecciona um planejamento adequado de suas próximas ações, tende a encontrar mais facilidade ao longo do processo.

Foram escolhidos dois roteiros para uma análise mais específica. Os grupos responsáveis pela confecção serão denominados G1 e G2. Tal denominação também 
será utilizada em outros momentos da análise do projeto, como a análise pormenorizada dos vídeos produzidos, no Subitem 5.4. A decisão pela análise de dois casos particulares tem como objetivo examinar e investigar o percurso total dos integrantes desses grupos ao longo de todo o projeto. Foram selecionados grupos que proporcionaram, ao longo de todo o processo, aberturas importantes para análises e também apresentaram níveis diferentes de profundidade e envolvimento nas etapas percorridas.

Assim como a maioria, os grupos selecionados para essa análise detalhada do roteiro optaram por iniciar o roteiro registrando as respostas paras as cinco primeiras questões. Nas figuras seguintes, é possível observar que as motivações iniciais dos vídeos são distintas por conta da seleção de público-alvo. Os estudantes do G1 optaram por explicar e aprofundar a ideia de possibilidades e espaço amostral para alunos de sua de aula que já estudaram os conceitos iniciais de probabilidade.

Figura 13 - Recorte do roteiro do grupo 1

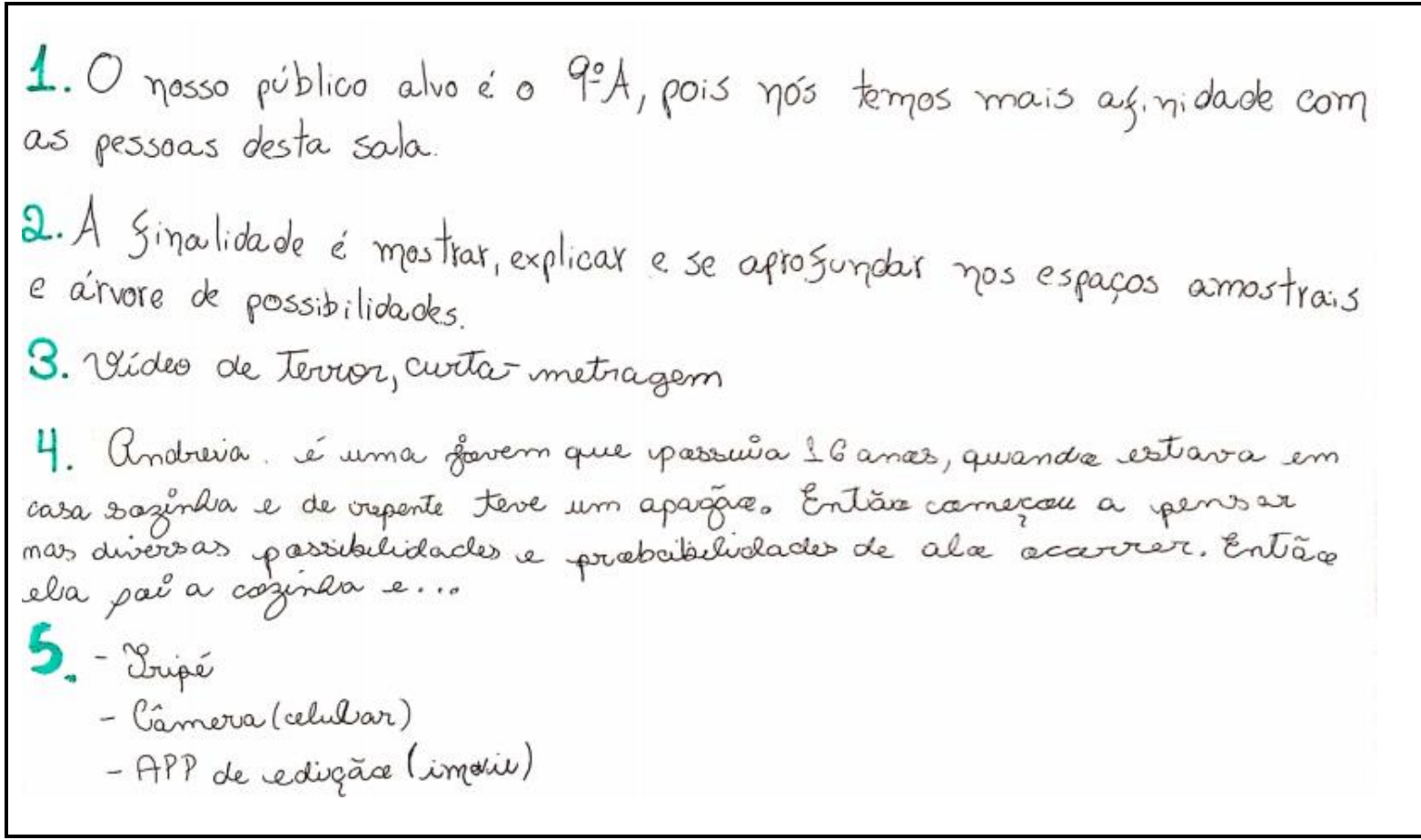

Esse grupo (G1) decidiu produzir uma narrativa de terror voltada aos alunos do próprio $9^{\circ}$ ano que desejassem retomar conceitos estudados, na qual uma adolescente está sozinha em casa, ouve um ruído estranho e levanta hipóteses de sua causa. Já os alunos do segundo grupo (G2) decidiram introduzir as ideias de probabilidade para alunos em transição do $8^{\circ}$ para o $9^{\circ}$ ano que ainda não tiveram 
muito contato com a temática. A produção consistiu na apresentação de uma narrativa de dois personagens calculando probabilidades de vencer em um jogo de bingo. Abaixo pode-se observar um trecho do roteiro deste grupo.

Figura 14 - Recorte do roteiro do grupo 2

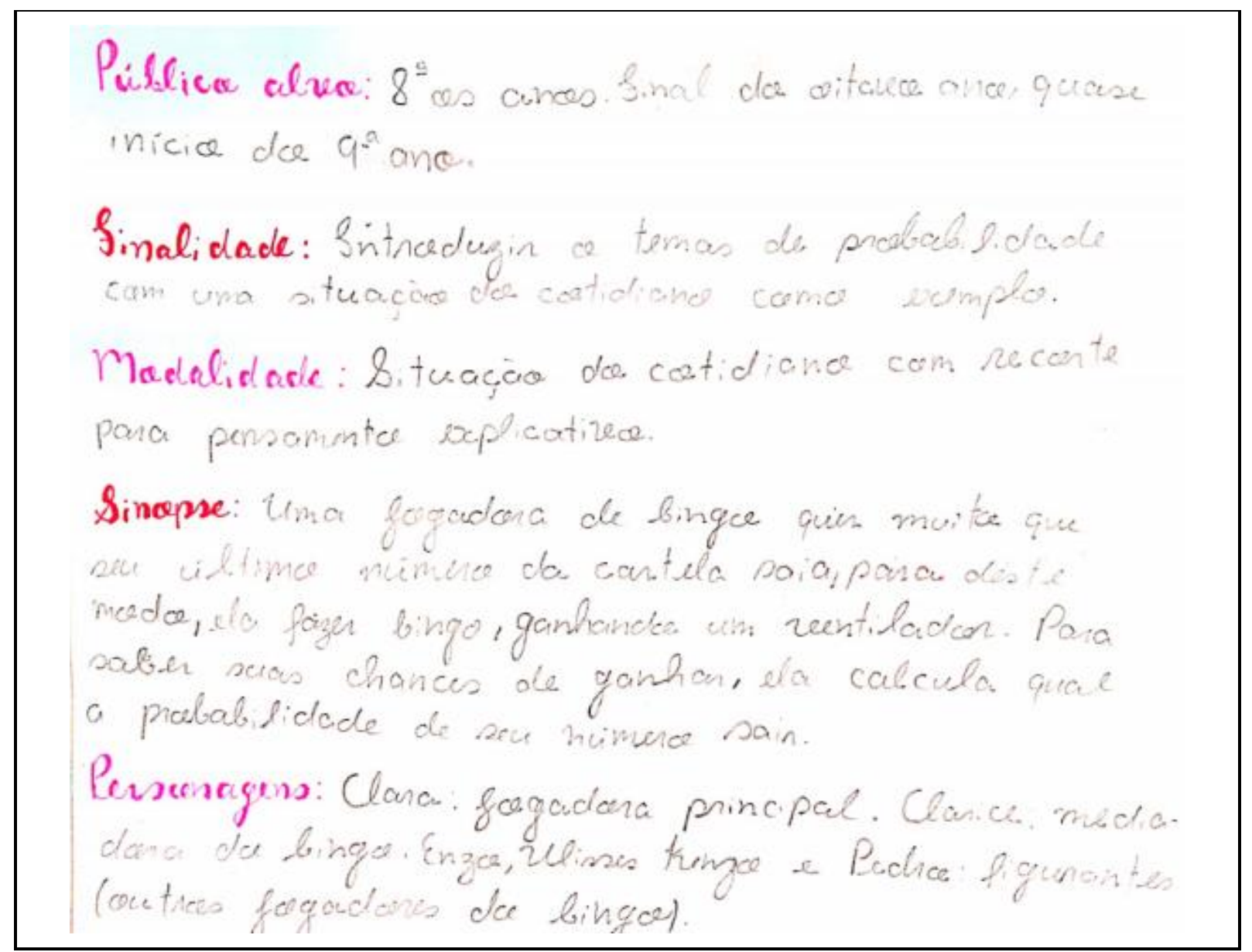

Uma grande diferença entre os roteiros escolhidos que ilustra e representa a diversidade de roteiros confeccionados no projeto é o fato de um dos grupos ter optado por uma breve descrição das cenas com a ideia principal presente em cada uma, enquanto o outro grupo decidiu descrever com mais detalhes as falas das personagens e efeitos de edição que surgiriam em determinados momentos. É válido recordar que a proposta deixava em aberto o modelo do roteiro e que era esperado que os alunos percebessem por conta própria que um planejamento adequado de roteirização fornece subsídios que facilitam os momentos de gravação e edição, como apontou Oechsler, Fontes e Borba (2017).

A figura abaixo apresenta mais um recorte de trechos do roteiro em questão e auxiliam na observação da diferenciação dos modelos escolhidos. 


\section{CENAS}

CENA 1: Cndreia assistinulo TV Qnamulo a luo acaba - grito

CENA 2."Parsibulidade (Ventro)*

CENA 3: Passibilidacle (mäe desligan a quadras) ${ }^{*}$ (Expliciativas

CENA 4: Passibilidade (assaltante)

CENA5: Valta a vealidade ecarre quadras "que me CENA 6: Lentra dra cazinaz ue elepara cam a manstra dar vima CENA 7: Passibilidade (lugar a yaca e es paquear ele até marre) 3 CENA 8: Passibilidade" (Pegar un capa de vidra e quebrar nal CENA 9: Passibilidade (corerer)*

CENA10: Andreia e a Manstra se encaram, comegam a irinear" cam a lez - quitos e comentáruas

CENA 1.1: Manstrua desaparece e Andreia carre para a sala - "OFA" CENA 12: Andreia valta a assistir TV. -

Este trecho do roteiro do G1 representa toda a descrição do que os integrantes decidiram gravar e editar. Nota-se que embora estejam presentes alguns registros e anotações de efeitos e intenções, a enumeração das cenas em conjunto com as ideias principais serviu para o grupo apenas como um esqueleto para a gravação. Muitos desdobramentos ficaram apenas nas discussões e outros devem ter surgido apenas no momento de gravação.

O trecho do roteiro do G2 apresentado abaixo representa uma pequena parte da descrição das intenções de gravação e edição do grupo. É possível perceber que, diferente do roteiro acima apresentado, há previsões de movimentos de câmera, textos e números surgindo na tela elucidando ideias matemáticas, além de falas e narrações descritas com detalhes. 


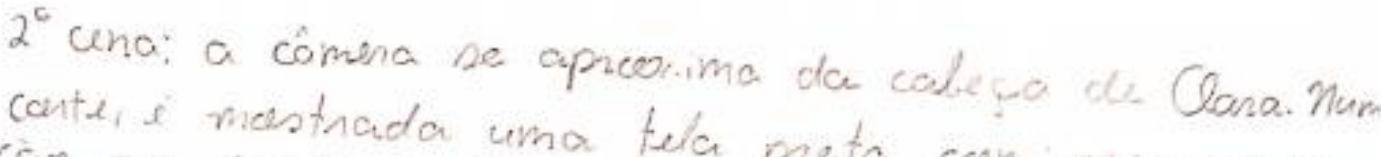

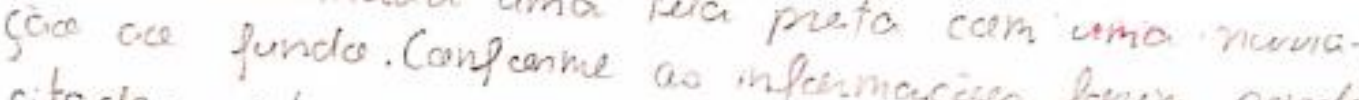

$$
\begin{aligned}
& \text { citadas, estas seria as infeimagenes ferun sendo } \\
& \text { * esa nanacia senia ou tía } \\
& \text { Uary un afh: Bom,does } 90 \text { numeres de feegar, fo. } \\
& \text { nee de pees bifidades, an sega, as numences ques oinots } \\
& \text { prokm sair. Eu quance I numenee entre esses deg (aum. } \\
& \text { na calcular a minha predab. Pidade ou sefa } \\
& \text { ces dee que the qunce a contecer, ber vese the que thoth }
\end{aligned}
$$

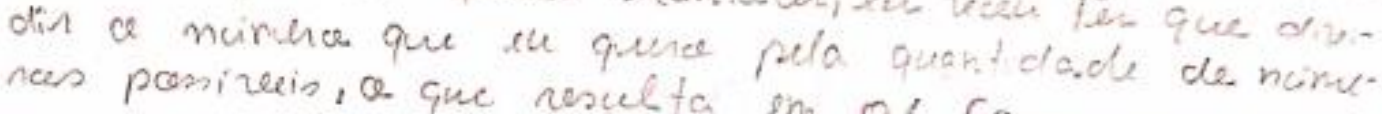

$$
\begin{aligned}
& \text { tramformale } 0,1 \text {. Casce quenomes }
\end{aligned}
$$

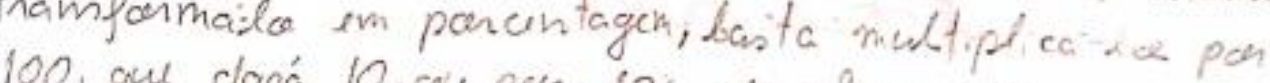

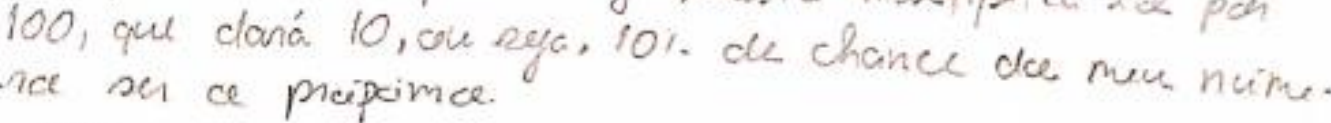

$$
\begin{aligned}
& \text { Lepois dise pensanunto, Clasa acaba perabendes } \\
& \text { que seu nuimence peede sain com ce tantee de chance } \\
& \text { puanter os autions. }
\end{aligned}
$$

De maneira geral, a roteirização proporcionou reflexões importantes para os estudantes, a partir do momento em que se sentaram para planejar e discutir sobre a produção proposta. Por se tratar de um momento destinado à discussão, estudo e pesquisa acerca dos conteúdos conceituais, abriu-se espaço para diversas mediações da professora a respeito de tópicos relacionados aos conceitos de probabilidade. Pode-se observar diversas oportunidades para a interação da professora com os alunos, cumprindo papel descrito por Moran (2018) de ajudar alunos a irem além de onde conseguiriam ir por conta própria, segundo o autor, "o papel principal do especialista ou docente é o de orientador, tutor dos estudantes individualmente e nas atividades em grupo, nas quais os alunos são sempre protagonistas" (p.5). 
O pesquisador, por sua vez, não foi uma simples observador do processo. $A$ meta nesse momento era o efetivo envolvimento e a real participação de forma ativa para melhor compreender a atividade matemática dos estudantes ao longo desse experimento de ensino, como apontam os autores Steffe e Thompson (2000).

\subsection{Vídeos}

Ao longo de duas aulas em cada turma, foram exibidos os vídeos produzidos pelos alunos. Até o momento das apresentações, estava combinado com as três turmas que tratava-se da mostra das produções finais. No entanto, após comentários dos colegas e das reflexões realizadas em sala de aula, guiadas pela professora e pelo pesquisador, surgiu, de maneira espontânea, a vontade dos estudantes de realizar refilmagens. Tal demanda foi muito bem recebida e, ao final da exibição, acordou-se que aquelas produções seriam as primeiras versões e que após o intervalo de duas semanas, seria organizado um festival com a apresentação das versões finais.

Este subitem da análise será dividido em três etapas. Nas duas primeiras serão analisadas as duas produções dos grupos G1 e G2 (primeira versão e versão final). Por fim, serão explorados aspectos gerais das demais produções das três turmas.

\subsubsection{Vídeos do G1}

Para iniciar a análise das duas produções dos alunos do primeiro grupo, alguns trechos do diálogo coletivo entre professora, pesquisador e os alunos da sala referente a esse grupo foram selecionados e transcritos. Nesse momento, dentro do projeto, garantiu-se "uma parada para reflexão, feedback (...), discussão com outros grupos e atividades para melhorias de ideias" (MORAN, 2018).

Os dois quadros seguintes apresentam falas realizadas logo após a apresentação da primeira versão do G1 . 
Término da apresentação do vídeo

Sala: (aplausos)

Aluno A: Que legal! Vamos ver de novo?

Aluna B: Mano, é genial!

Professora: Legal..., mas é didático? Acrescentou para vocês? E para uma pessoa que nunca viu, entender?

Sala: (risos)

Aluno C: Não explica mais o que é probabilidade porque o espaço amostral é muito simples.

Professora: E na verdade fala de um espaço amostral que na verdade é infinito e não é equiprovável. A possibilidade dela gritar, sair correndo ou machucar ou fazer as três coisas ao mesmo tempo... ou podia ter acontecido ... o acaso poderia ter intervindo de infinitas maneiras aí. Quem gostaria de falar? O próprio grupo olhando agora... gostaria de mudar alguma coisa?

Aluna D: É, depois que eu vi pronto o vídeo, eu achei que ele não é tão didático quanto acho que vocês queriam, mas acho que dava para entender as possibilidades, o espaço amostral...

Professora: Retoma pra mim. Qual era o público-alvo?

Aluna E: do G1: Os alunos do 9A.

Professora: $9^{\circ} \mathrm{A} \ldots$... e é só uma revisão?

Aluna E - do G1: Uhum.

Professora: E para quem não tinha entendido o que especificamente?

Aluna E do G1: O espaço amostral. Acho que não ficou como vocês esperavam

Professora: Mas o que que a gente esperava?

Aluna $E$ do $G 1$ : Eu acho que vocês não queriam um videoaula, uma lousa com alguém falando, mas vocês queriam alguma coisa indiretamente, mas didático.

Aluna F: Uma explicação mais detalhada?

Professora: Uma explicação mais detalhada.

Aluna G do G1: Talvez a explicação tenha sido meio vaga se tivesse focado mais no conteúdo.

Neste outro trecho, é possível observar uma resposta de um aluno frente à uma pergunta realizada pelo pesquisador. 
Quadro 20 - Transcrição de recorte de discussão coletiva na apresentação do G1

Pesquisador: Coloquei também algumas coisas que a Fabi já falou, do espaço amostral do erro de português. Alguns alunos falaram: "esclareceu um pouco o conceito de espaço amostral" Não sei... o que é o espaço amostral... alguém conseguiria me dizer?

Professora: A partir do vídeo.

Aluno $\mathrm{H}$ : Eu... são as possibilidades. As possibilidades, nesse caso, como falaram não era equiprovável e o espaço amostral é infinito. Mas no caso... é... vou te dar um exemplo, no jogo de futebol não o placar em si, mas quem vai ganhar e quem vai perder. Ah, e o empate... então seria: vitória do time A, vitória do time B ou empate. Isso seria o espaço amostral do jogo.

Fica claro, após a leitura das transcrições da discussão coletiva, que houve um grande esforço dos integrantes do grupo para produzir um material capaz de prender a atenção de seus espectadores, com cenas de tensão apresentando possíveis causas de um ruído ouvido por uma garota em um determinado instante de uma noite em sua casa. No entanto, o grupo não consegue esclarecer para o espectador a resposta da pergunta inicial que aparece no vídeo: "O que a probabilidade tem a ver com filme de terror" e, além disso, deixa a impressão de que há um número finito de possibilidades para a causa do ruído.

Outro aspecto relevante que despontou na reflexão gerada pelo vídeo foi notado nas falas de colegas. Havia no grupo de alunos, estudantes com dificuldade em relação à noção de espaço amostral e na análise de suas possibilidades. A abertura de um espaço de reflexão pós exibição do vídeo dos alunos do G1 foi essencial para que a sala pudesse revisitar conceitos importantes sobre probabilidade. A meta do vídeo, que era esclarecer esses tópicos, não foi atingida, mas abriu esse espaço de reflexão e retomada a respeito desses conhecimentos. A fala do aluno $\mathrm{H}$, por exemplo, apresenta um encaminhamento interessante aos demais colegas.

Por sugestão da professora, os estudantes assistiram a todos os vídeos exibidos registrando suas impressões. Para isso, a turma recorreu a uma dinâmica já estabelecida entre eles. Cada aluno organizaria suas impressões de cada vídeo em três tópicos: "que bom", "que pena" e "que tal". O primeiro tópico contemplaria os pontos positivos da produção analisada, o segundo abrangeria os aspectos em que o 
grupo poderia ter desenvolvido de outra maneira e o último incorporaria sugestões e recomendações visando a melhoria do trabalho.

Abaixo pode-se ver as observações de um aluno a respeito do vídeo apresentado pelo $\mathrm{G} 1$ no formato descrito acima.

Figura 17 - Observações de aluno sobre vídeo do G1

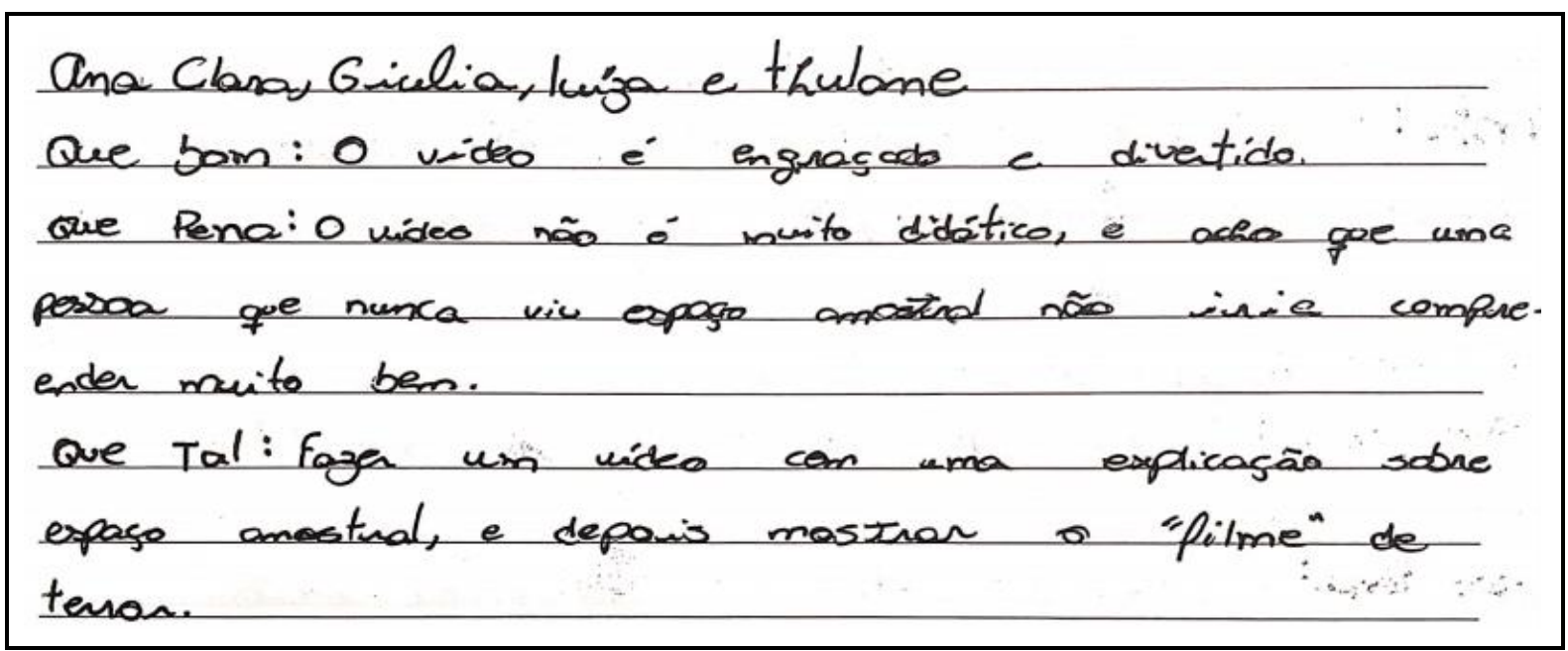

Nas anotações deste aluno, é possível identificar o principal aspecto positivo do vídeo apresentado pelo grupo de colegas: a narrativa divertida de um filme que alterna terror com humor. Além disso, nota-se que o estudante avaliou que faltava bastante conteúdo e propôs uma introdução explicativa às cenas apresentadas pelo grupo.

Em outro registro, desta vez fugindo um pouco do formato proposto, pode-se perceber críticas positivas a aspectos técnicos e uma constatação de ausência de explicações a respeito do espaço amostral de um experimento aleatório. 


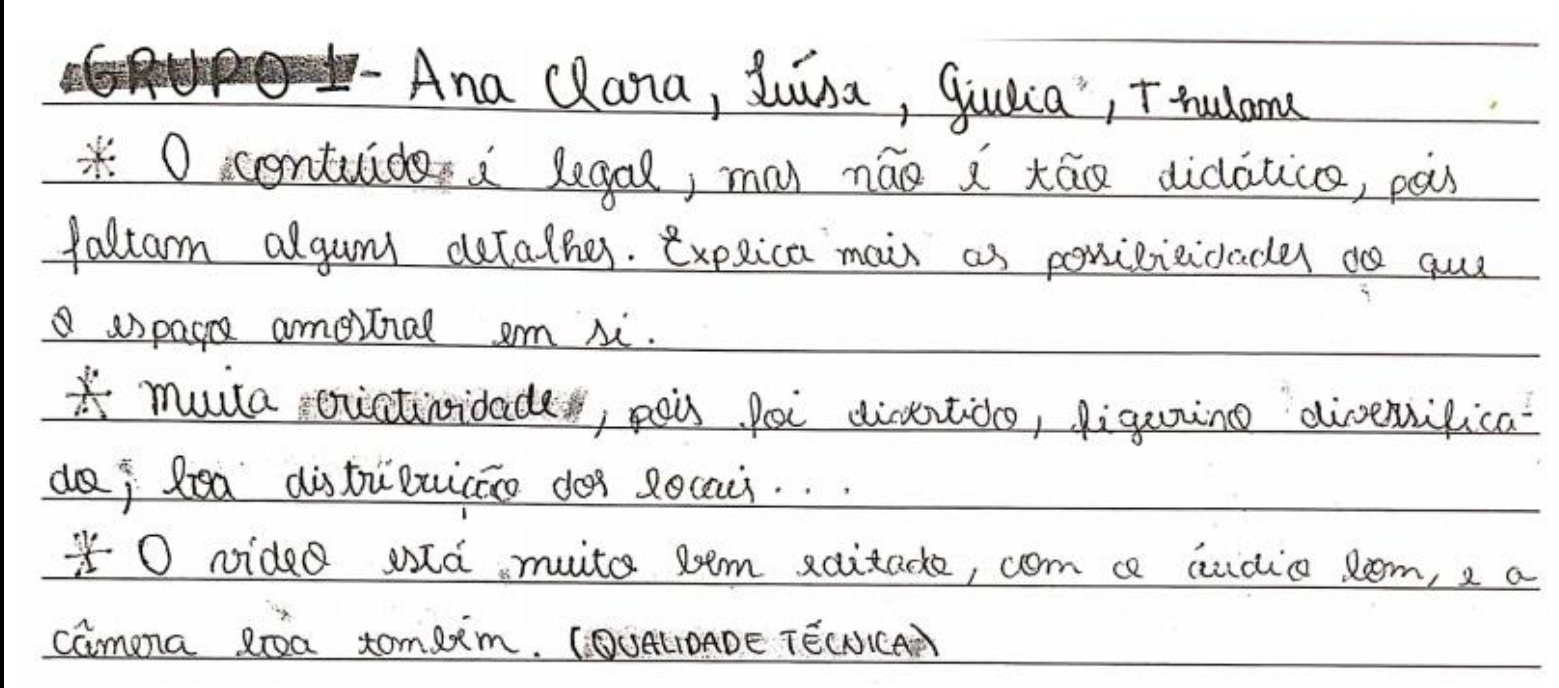

Ao longo das duas semanas seguintes, o grupo passou pelo processo de refilmagem e no momento do festival apresentaram uma versão que contemplou grande parte das sugestões levantadas na discussão. Fica evidente, nessa etapa de construção e reconstrução, que a aprendizagem ocorreu baseada em processos de questionamento e experimentação, caracterizando-se assim como uma aprendizagem mais ativa. Como aponta Moran (2018), tais aspectos são essenciais para se conceber compreensões mais amplas e profundas acerca dos objetos que se pretende estudar.

A primeira mudança foi sutil e ocorreu nas apresentações do conjunto que contém as possibilidades. Pode-se observar na figura abaixo a inclusão das reticências indicando que esse conjunto contém infinitos elementos.

Figura 19 - Frames dos vídeos produzidos pelo G1

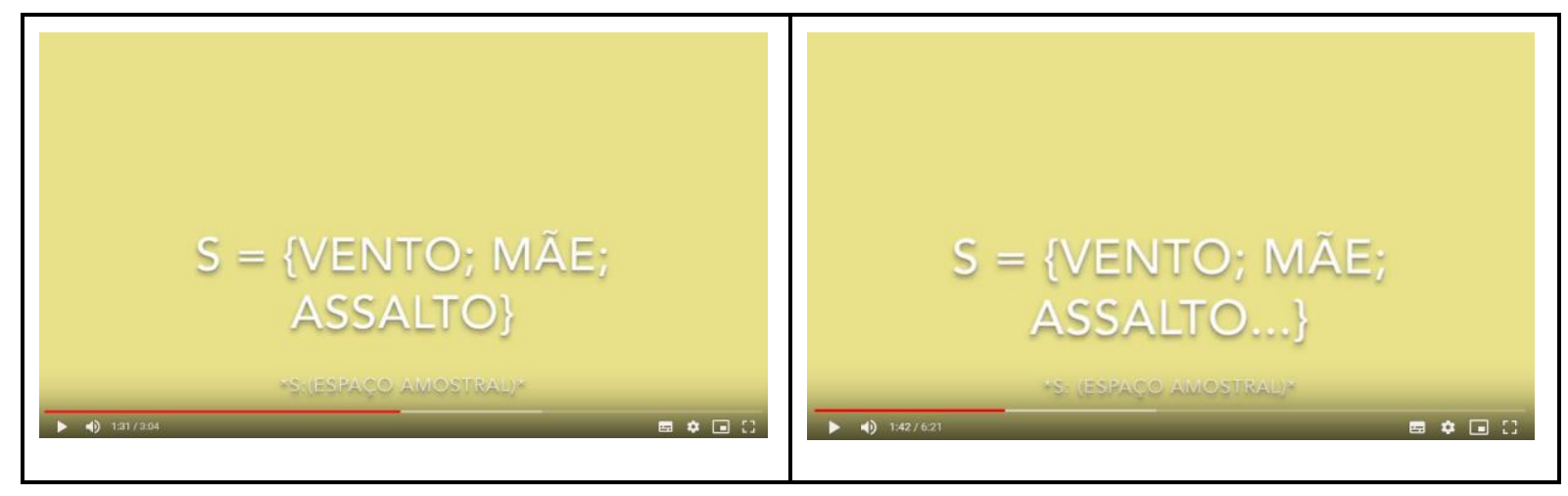


Além disso, como forma de potencializar o caráter didático do vídeo e trazer ao espectador mais particularidades relacionadas ao estudo de probabilidade, os integrantes incluíram 3 minutos e 15 segundo ao final da produção - que tinha inicialmente apenas 3 minutos e 6 segundos - com cenas apresentando os bastidores do filme de terror. Desta forma, os estudantes dobraram a duração do vídeo com cenas em um ambiente que aparentava ser um camarim. As atrizes que protagonizaram as cenas gravadas e a diretora, desenvolveram diálogos explicativos a respeito da noção de espaço amostral e da diferença entre possibilidade e probabilidade.

Utilizando recursos de edição, o grupo conseguiu expor animações que trouxeram ao espectador exemplos de espaços amostrais relacionados à experimentos simples - lançamento de dado e moeda - com artifício da narração de uma aluna que representava a diretora do filme de terror. Destaca-se aqui que houve esforço dos integrantes em desenvolver o que Moran (1995) apontou como potência dos produtos audiovisuais: "linguagens que interagem superpostas, interligadas, somadas, não separadas. Daí a sua força. Nos atingem por todos os sentidos e de todas as maneiras" (p.28).

Figura 20 - Frames dos vídeos produzidos pelo G1

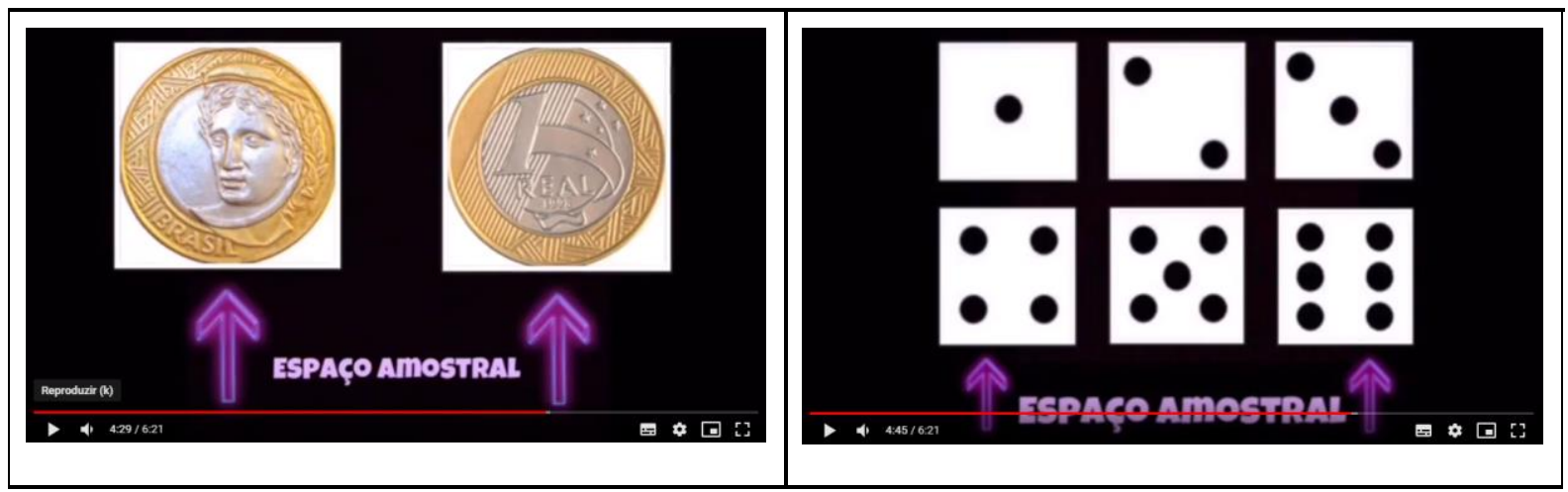

Com isso, os integrantes do grupo relacionaram o conteúdo estudado de probabilidade com o filme de terror apresentado e assim esclareceram alguns pontos levantados na discussão após apresentação da versão inicial.

De maneira geral, o vídeo agradou bastante os jurados após a exibição no Festival e foi considerado a melhor produção das turmas. 


\subsubsection{Vídeos do G2}

Novamente, a análise da versão inicial e final dos alunos do grupo em questão, será iniciada pela transcrição de parte da discussão coletiva após a exibição da primeira versão para os alunos, professora e pesquisador.

Quadro 21 - Transcrição de recorte de discussão coletiva na apresentação do G2

Término da apresentação do vídeo

Sala: (aplausos)

Pesquisador: E aí, gente?

Professora: Quem vai começar?

Aluna A: Eu! Eu achei muito fofo. Eu gostei, achei engraçadinho, na real. Na verdade eu não tenho muito o que falar. É que, tipo assim... como eu sei o conteúdo, pra mim é fácil de entender. Na real, é isso. Eu sei, então eu consigo entender. Não sei uma pessoa que não conhece todo o conteúdo, conseguiria entender.

Pesquisador: Mas te trouxe alguma contribuição?

Aluna A: Sim.

Aluna B: É que a gente já aprendeu probabilidade, né?

Pesquisador: Então é uma retomada?

Aluna B: É, isso. É uma retomada.

Pesquisador: E como retomada você achou válido?

Aluna B: Válido.

Aluna $\mathrm{C}$ do G2: O nosso público alvo não era o nono. era tipo, o oitavo ano. e a gente ia mostrar mais ou menos qual era o conteúdo de probabilidade do nono.

Pesquisador: Tá. Por ser o oitavo ano, você acha que está clara essa parte aqui?

(Pesquisador repete trecho do vídeo: “...a gente pega o total de números do bingo, pelos já lançados, e isso vai dar dez. agora vou precisar dividir o número de elemento que quero pelo número de possibilidades...")

Pesquisador: Tá tranquilo para o oitavo?

Aluna $C$ do G2: É... não... 
$\mathrm{Na}$ transcrição do primeiro trecho da discussão, é possível perceber que colegas de fora do grupo pontuam que compreenderam os conceitos apresentados por já terem os estudado, mas caso fosse um primeiro contato, possuem dúvida sobre a clareza da apresentação desses conceitos. Tais colocações trouxeram o questionamento sobre a adequação à linguagem adequada para o público-alvo escolhido: alunos em transição do 8ำ para o 9ำ ano.

Quadro 22 - Transcrição de recorte de discussão coletiva na apresentação do G2

Professora: Acho que falta aí, qual é a definição de probabilidade, como se calcula. E na própria escrita, no desenho, identificar o que que esse noventa significa? O que que esse oitenta significa? Você fala, mas ela se perde, né. Depois quando vai mais pra frente eu já não lembro mais. O que era noventa mesmo? Por que que era oitenta? ... E tem uma outra coisa na escrita que eu pego no pé de vocês.

(Professora reproduz trecho de vídeo em que aluno emenda cálculos e apresenta uma afirmação matemática equivocada: “...dividido por 10, e isso vai dar 0,1 e para transformar em porcentagem eu tenho que multiplicar isso por 100 que vai dar $10 \%$. então tenho $10 \%$ de chance.)

Professora: Aí fica como se 1 dividido por 10 fosse igual a 10. E não é.

Pesquisador: Nessa afirmação aqui tá escrito "um décimo é igual a 10".

Aluna D do G2: Um décimo igual a dez?... Ah tá! É... entendi.

Professora: Você tem que colocar um sobre dez já vezes cem desde o princípio. Ou colocar numa outra linha. Não tudo igual. Lembra quando vocês começam a fazer uma coisa, sei lá, tem que achar o resultado e a resposta do problema é o resultado vezes três. E você chega lá, xis é igual a cinco aí emenda na mesma linha: vezes três, igual a quinze? Tem que escrever na outra linha, separado. Foi isso que aconteceu ali.

Pesquisador: É emendou alguns cálculos.

Aluna D do G2: É... percebi.

Nesse momento da discussão houve uma grande abertura para discussão da escrita das afirmações matemáticas. Há uma retomada da professora relacionada à algumas imprecisões ocorridas em outros momentos do curso, que mostra-se pertinente pois o vídeo é um registro realizado pelos alunos e deve ser comunicativo e não apresentar dualidades na interpretação das afirmações. Sendo assim, caracteriza-se como um momento no qual o aluno necessita recorrer a algumas formalidades que convencionam a linguagem matemática. 
Abaixo é possível analisar o trecho do vídeo que gerou a reflexão em sala de aula.

Figura 21 - Frames dos vídeos produzidos pelo G1

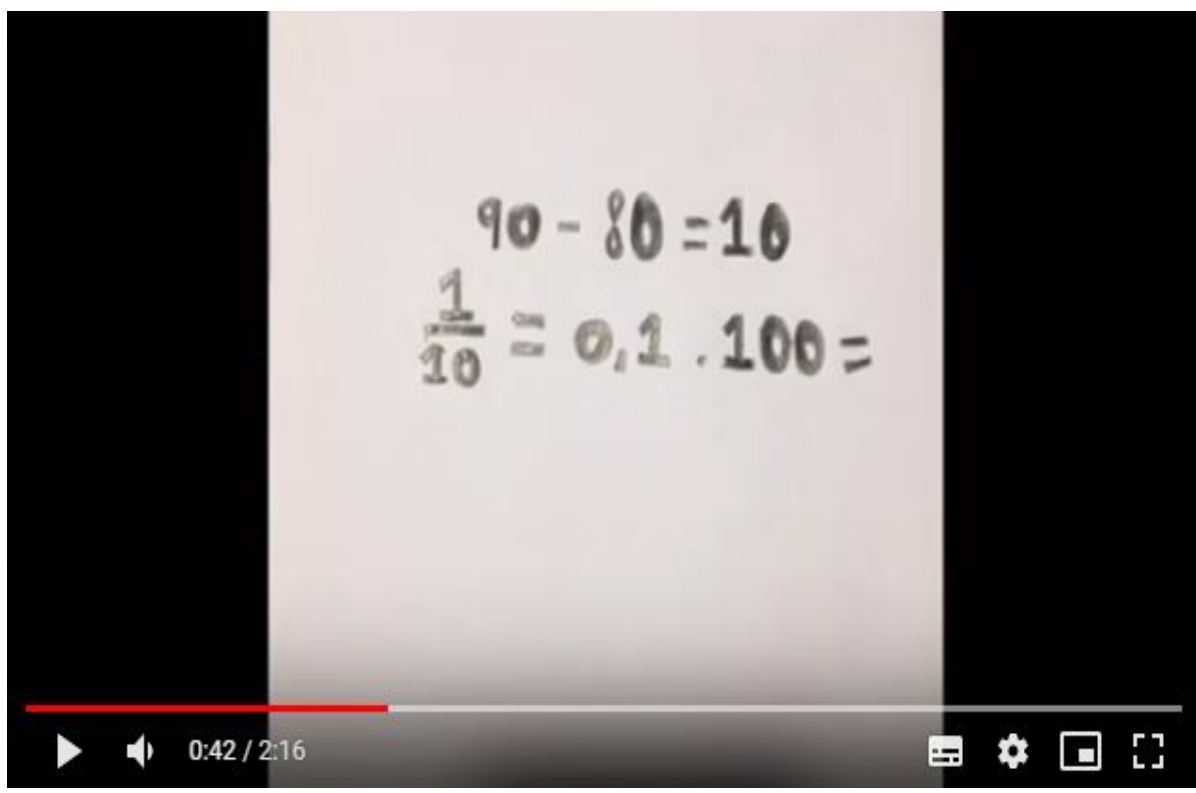

De maneira geral, a primeira versão vídeo foi bem avaliada pela turma em relação a criatividade e enredo, pois os colegas gostaram bastante da ideia de ambientar a narrativa em um jogo de bingo. É possível notar pelos registros dos estudantes que as propostas de melhoria para a produção passam necessariamente pela adequação à linguagem e apresentação dos conceitos ao público-alvo.

Figura 22 - Observações de aluno sobre vídeo do G1

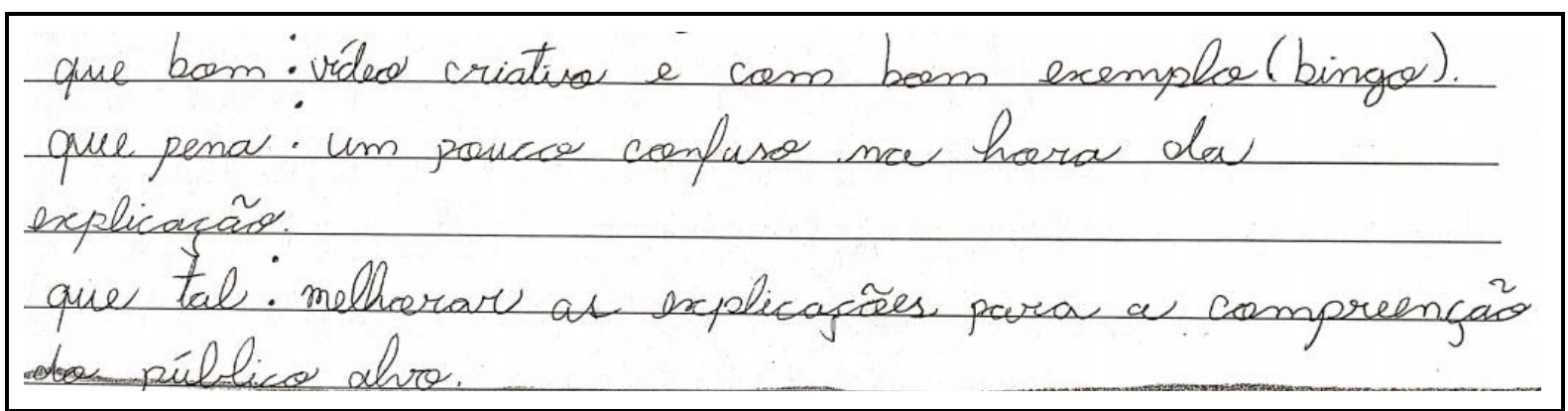

No registro abaixo, pode-se analisar as observações de um dos integrantes do grupo em questão após as discussões coletivas relacionadas a apresentação da primeira versão do seu grupo. O modelo "Que bom, que pena, que tal" foi complementado com observações gerais que pontuam a ausência de recursos de edição que facilitariam a compreensão do espectador, como apresentação de cartelas 
de bingo com número já riscados para facilitar a compreensão de alguns números importantes no cálculo da probabilidade da protagonista ganhar no jogo.

Figura 23 - Observações de aluno sobre vídeo do G1

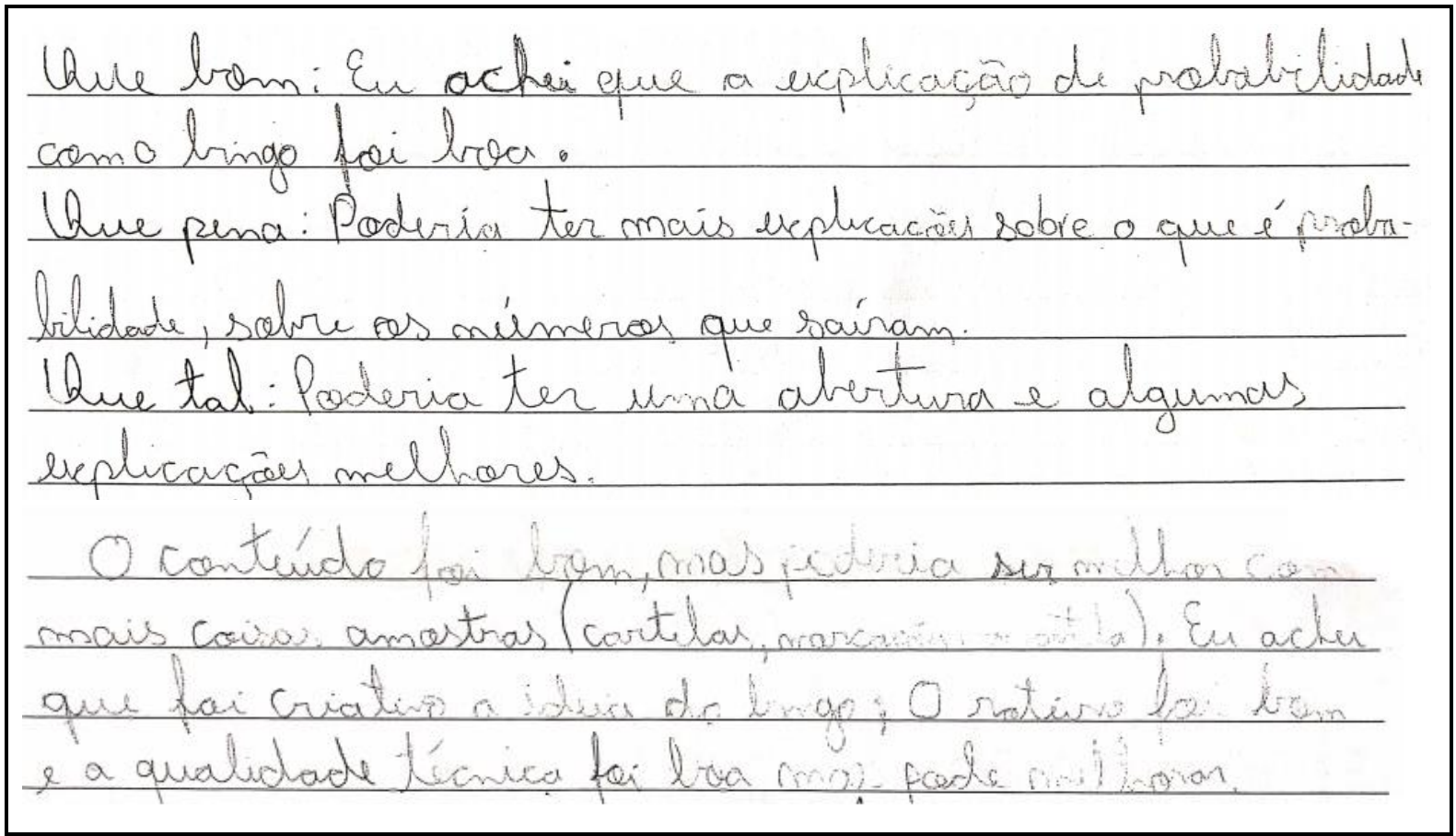

Além disso, é interessante observar que este aluno pontuou a ausência de uma abertura para a o vídeo. Tal levantamento não ocorreu de maneira coletiva, mas certamente foi uma constatação que o estudante posteriormente levou para seu grupo, pois no período de refilmagens e reedições, os integrantes do G2 efetuaram algumas melhorias em suas produções. A primeira delas realmente foi a inclusão de uma abertura que apresenta o título do vídeo escolhido pelo grupo. 


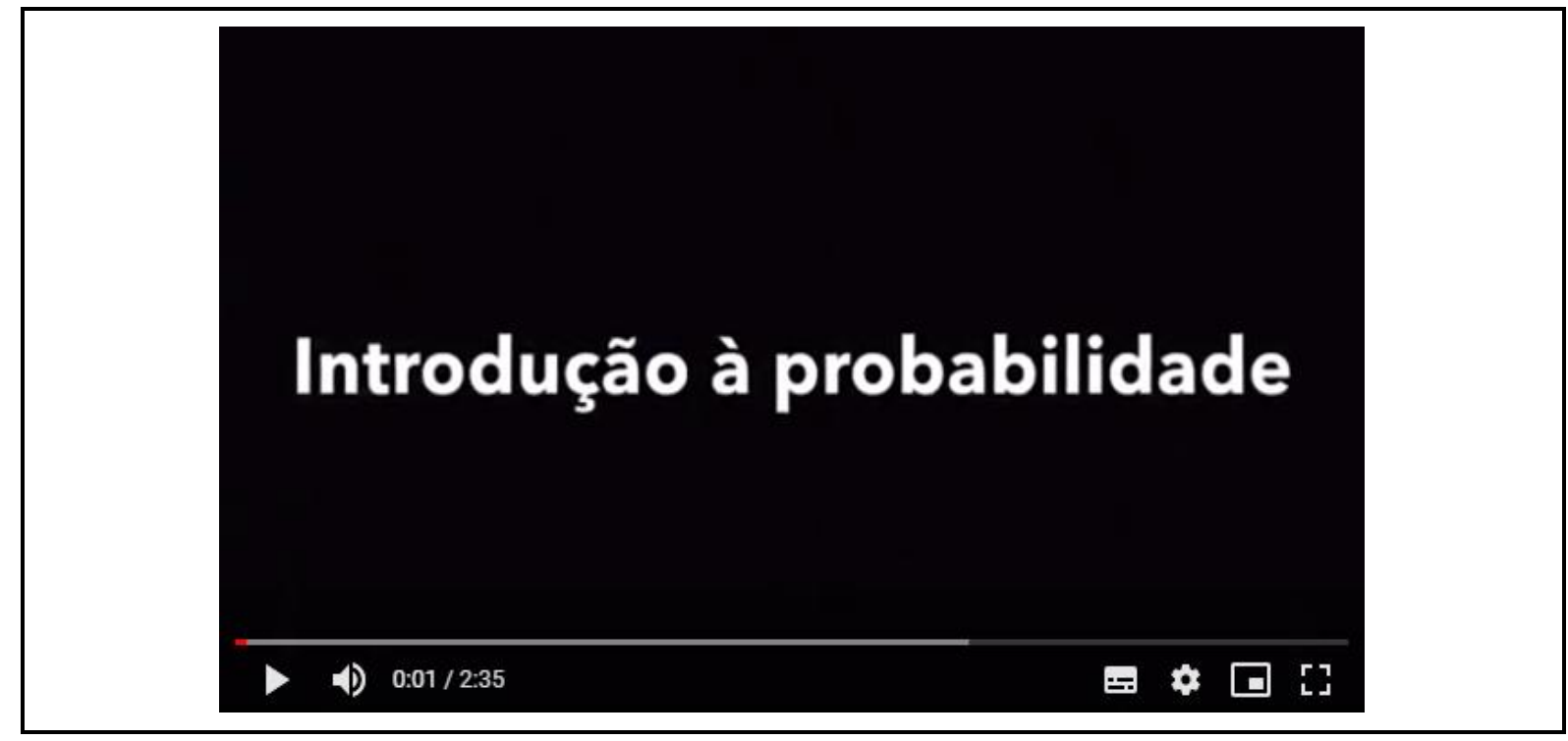

Ao longo dos 2 minutos e 35 segundos exibidos no Festival, outras adaptações puderam ser notadas. Os alunos abordaram a apresentação de um método para se atribuir valor à probabilidade de interesse baseado no modelo clássico e se dedicaram a apresentar todos os cálculos necessários para isso. Em relação a atribuição de valores à probabilidade de sucesso no bingo, o grupo elaborou uma introdução ao conceito clássico que analisa a razão entre o número de casos favoráveis - desejáveis - e o número total de casos possíveis.

Figura 25 - Frame de vídeo produzido pelo G2

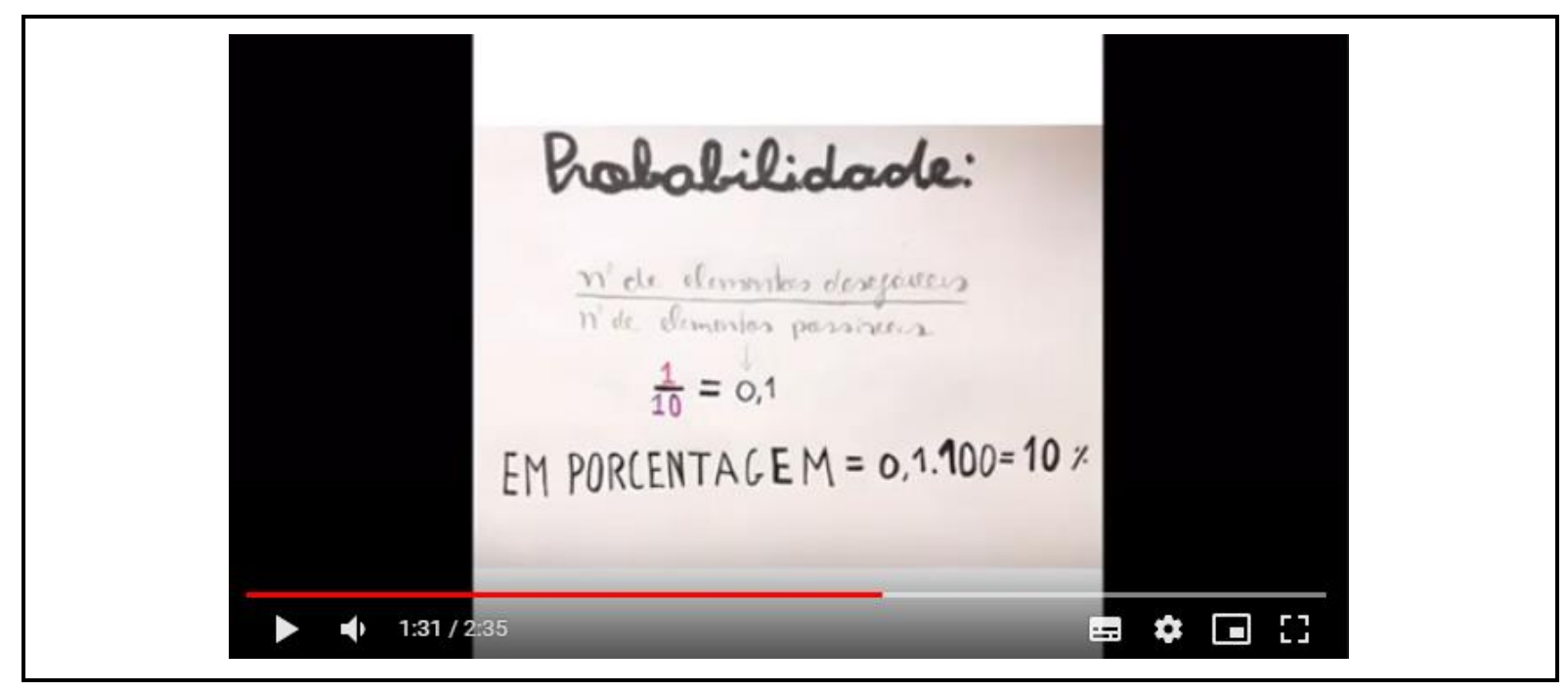

Outras melhorias na produção, que seguem observações realizadas em discussão coletiva, são: a inclusão de elementos de edição que facilitam a 
compreensão, como a cartela de bingo apresentada na Figura 26 e expressões verbais e textuais - podem ser visualizadas na Figura 27 - que apresentam ao espectador a origem de alguns valores numéricos utilizados no cálculo da probabilidade de interesse.

Figura 26 - Frame de vídeo produzido pelo G2

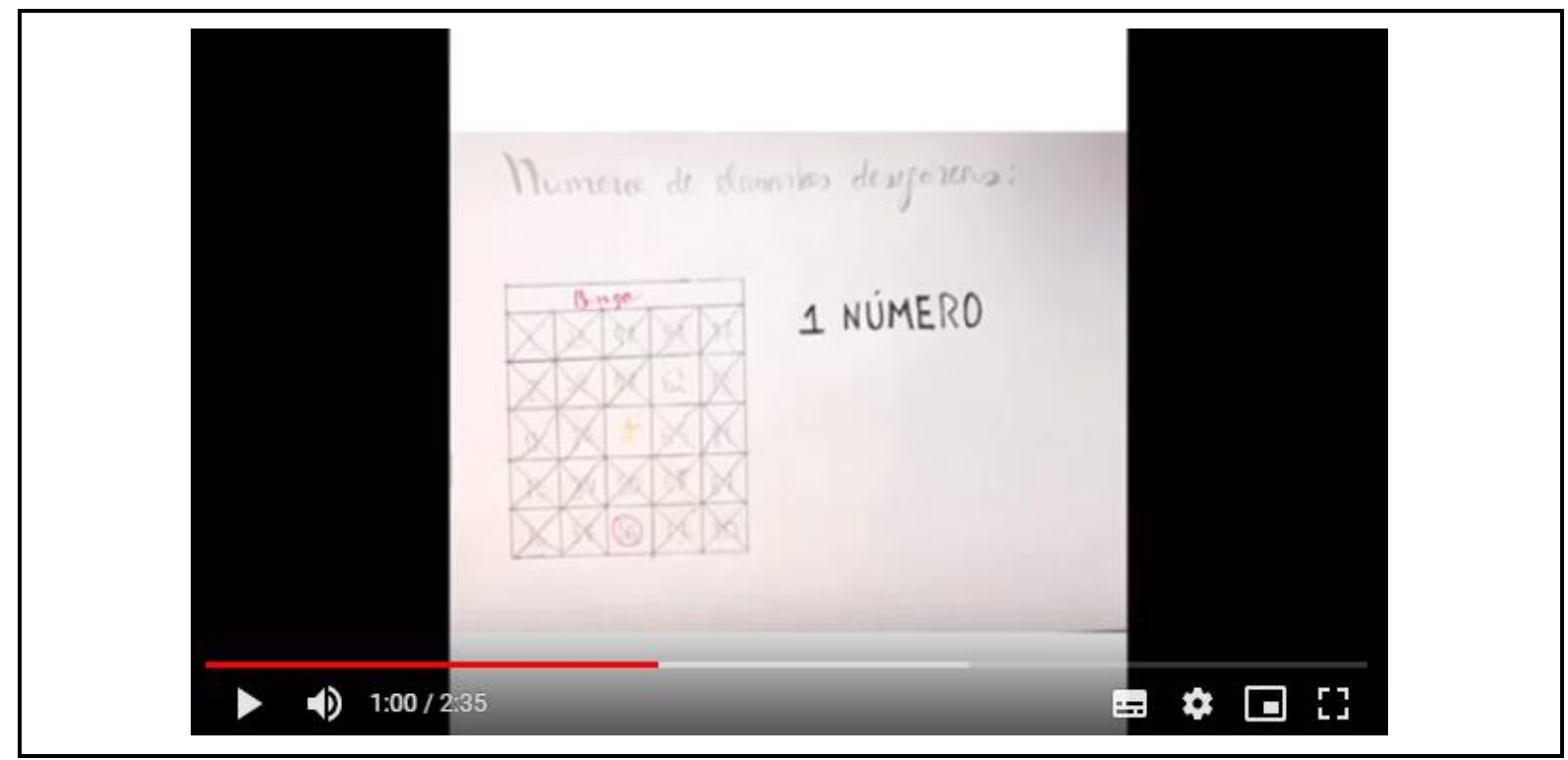

Figura 27 - Frame de vídeo produzido pelo G2

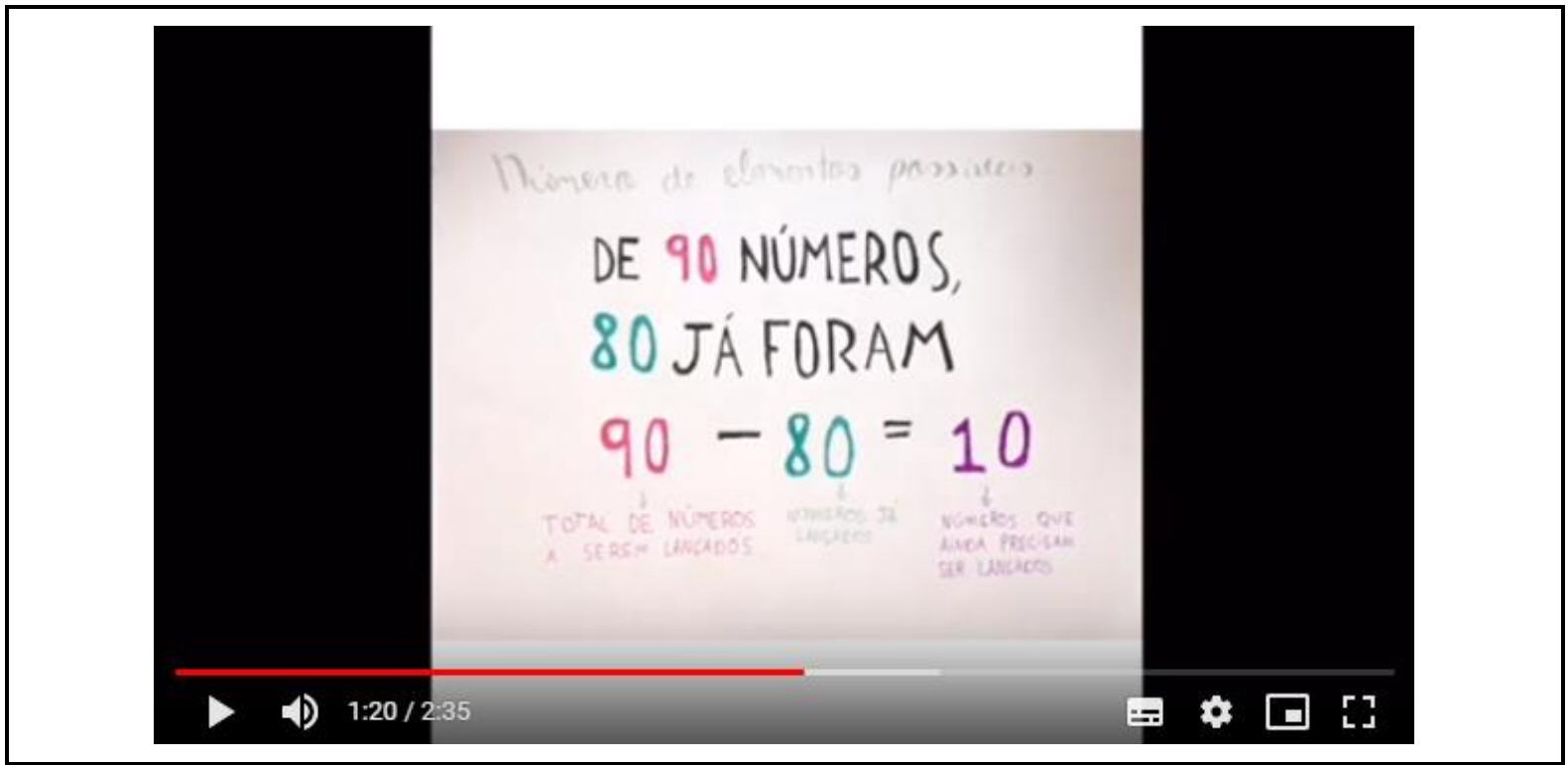

Embora o grupo tenha apresentado uma versão final bem curta e com recursos de edição não tão sofisticados quanto o grupo anterior, fica claro que o processo de análise coletiva e discussão foi importante para a etapa de reelaboração da produção. 
Deste modo, os integrantes puderam refletir e retomar questões importantes e, posteriormente, apresentá-las de maneira mais clara em seu vídeo.

É visível que um aluno iniciante nos estudos de probabilidade terá diversas contribuições ao assistir à produção e que os estudantes do G2 aprofundaram os estudos realizados no pré-projeto.

\subsection{Questionário final}

A aplicação do Questionário final carrega como pressuposto a realização de um comparativo com o Questionário inicial, mensurando assim os avanços conceituais do grupo de alunos ao longo da proposta. Conforme apresentado no Capítulo 4, as questões propostas são similares e fornecem um recurso que favorece a contraposição dos dados obtidos. Para isso, decidiu-se não realizar nenhum tipo de correção ou discussão coletiva dos resultados do primeiro instrumento, visando eliminar uma possível distorção da evolução conceitual dos alunos em detrimento de uma memorização de situações, estratégias ou respostas validadas pelo pesquisador ou pela professora.

É importante esclarecer que houve um grande intervalo de tempo entre a aplicação dos questionários. Tal fato ocorreu por conta das diversas demandas referentes ao final de primeiro semestre e causaram um intervalo de cerca de dois meses e meio, contando com as férias de meio de ano dos estudantes. Essas especificidades da aplicação dos questionários serão levadas em consideração na análise comparativa.

Logo na primeira proposição do Questionário final, é possível estabelecer a comparação com a Questão 3 do Questionário inicial. O quadro abaixo apresenta os detalhes, trazendo detalhes referentes às duas perguntas e os dados obtidos. 
Quadro 23 - Análise comparativa dos questionários

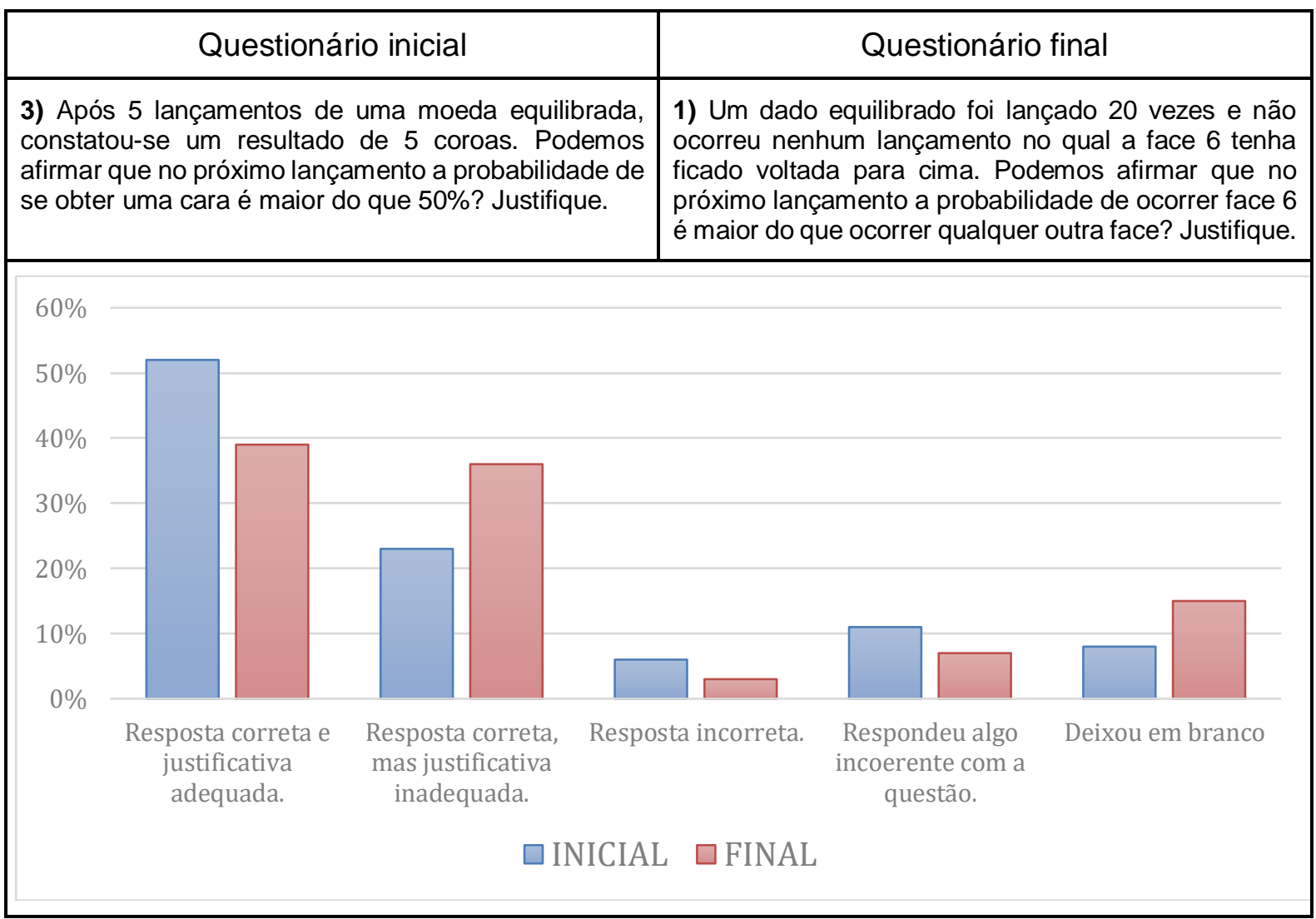

Tal questão possuía como objetivo avaliar a compreensão conceitual relacionada à natureza dos experimentos aleatórios e, como observa-se no quadro comparativo, os desempenhos dos estudantes foram similares. Embora o desempenho geral tenha piorado por conta de uma maior dificuldade de justificativa, ao se levar em consideração os que apresentaram resposta adequada (justificando corretamente ou não) tem-se um número igual: $75 \%$ de todas as respostas.

As questões 2, 3 e 4 do Questionário final, pretendiam avaliar aplicações práticas da atribuição numérica para probabilidade de ocorrência de eventos. As habilidades analisadas aqui são: listagem de possibilidades para composição de espaço amostral, princípio fundamental da contagem, leitura de tabela e aplicação da abordagem clássica de probabilidade. Os resultados podem ser analisados no quadro abaixo. 
Quadro 24 - Análise comparativa dos questionários

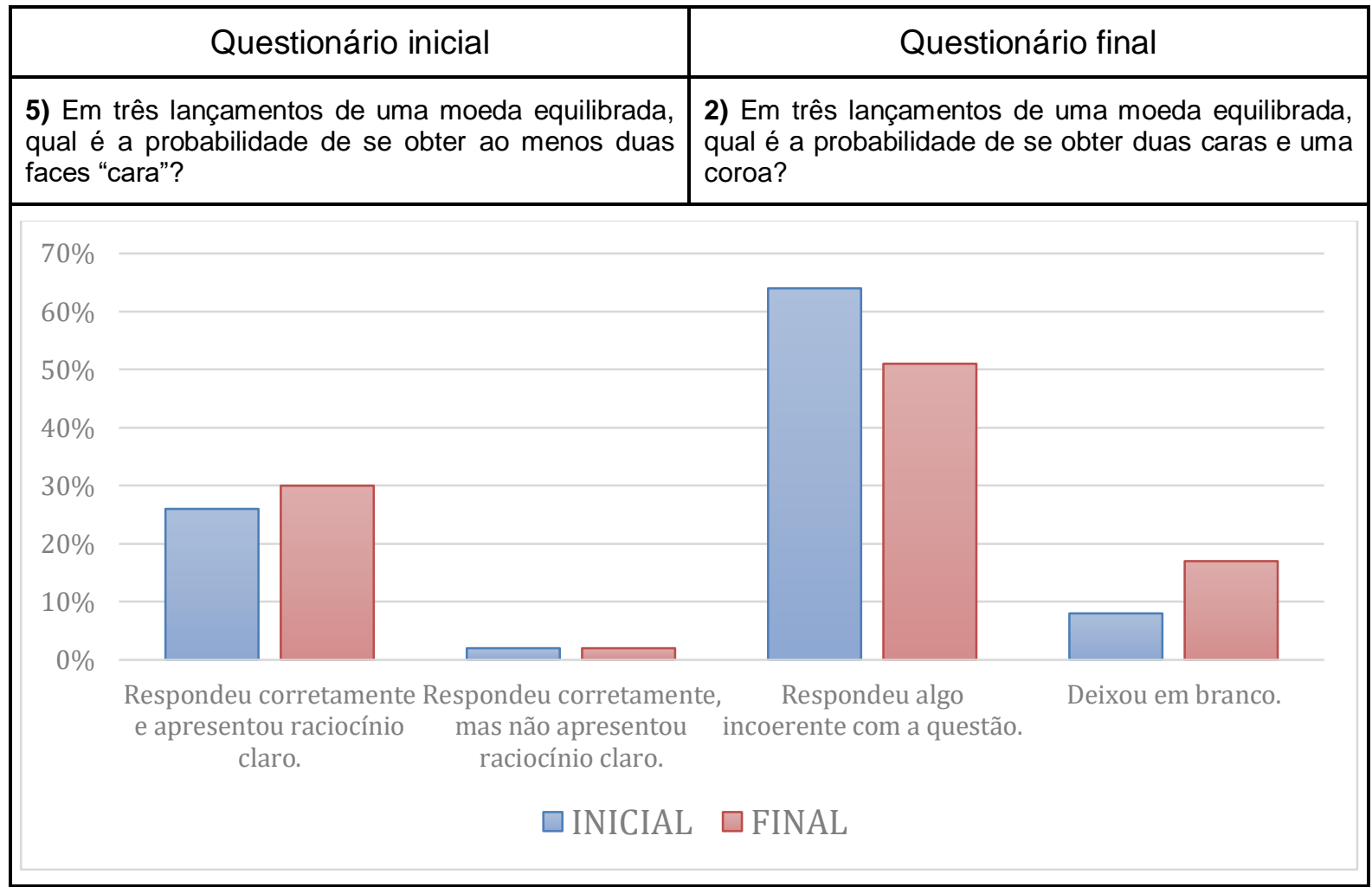

Quadro 25 - Análise comparativa dos questionários

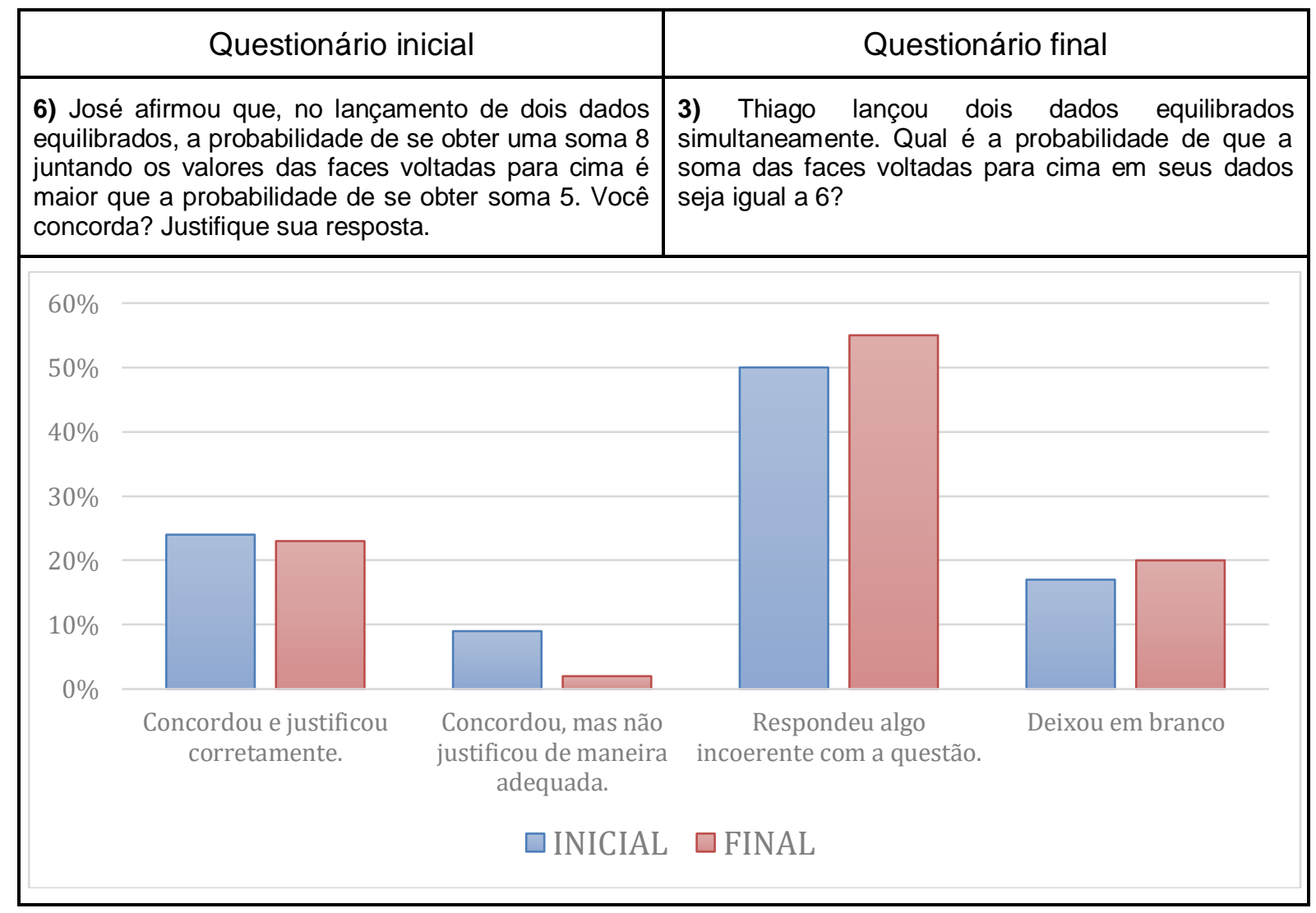


Quadro 26 - Análise comparativa dos questionários

\begin{tabular}{|c|c|c|c|c|}
\hline \multicolumn{3}{|c|}{ Questionário inicial } & \multicolumn{2}{|c|}{ Questionário final } \\
\hline \multicolumn{3}{|c|}{$\begin{array}{l}\text { 8) Sorteando-se ao acaso um indivíduo dentre } \\
\text { aqueles que praticam exercícios regularmente ou } \\
\text { irregularmente (dados na tabela), calcule a } \\
\text { probabilidade de que ele seja portador de doença } \\
\text { cardíaca. }\end{array}$} & \multicolumn{2}{|c|}{$\begin{array}{l}\text { 4) Sorteando uma pessoa ao acaso e sabendo } \\
\text { que ela tem interesse na realização do show } \\
\text { (dados na tabela), qual é a probabilidade de ela } \\
\text { ser da } 3^{a} \text { série do Ensino Médio? }\end{array}$} \\
\hline \multicolumn{5}{|l|}{$60 \%$} \\
\hline \multicolumn{5}{|l|}{$50 \%$} \\
\hline \multicolumn{5}{|l|}{$40 \%$} \\
\hline \multicolumn{5}{|l|}{$30 \%$} \\
\hline \\
\hline \multicolumn{5}{|l|}{$10 \%$} \\
\hline 0 & Respondeu corretamente. & 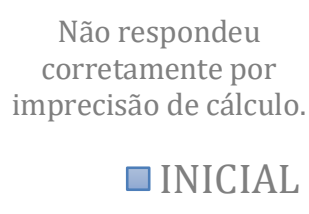 & $\begin{array}{l}\text { Respondeu de maneira } \\
\text { incorreta. } \\
\square \text { FINAL }\end{array}$ & Deixou em branco. \\
\hline
\end{tabular}

É possível observar nos gráficos comparativos apresentados acima que, embora tenha ocorrido um intervalo de tempo considerável e que, desta maneira, os alunos possam ter se distanciado do conteúdo específico investigado, houve questões com desempenhos muito similares, como as que foram apresentadas nos Quadros 25 e 26. Além disso, desponta um crescimento considerável ao se analisar a Questão 4 do Questionário final comparada com sua correspondente no Quadro 27.

Além das questões apresentadas acima, o questionário também oferecia aos alunos a possibilidade de avaliar sua própria trajetória ao longo do percurso. $\mathrm{Na}$ Questão 5, o aluno era convidado a atribuir uma nota de 1 a 10 para representar o quanto gostou de ter participado do projeto, enquanto na Questão na 6, a nota de 1 a 10 representava o quanto esse aluno acredita ter evoluído ao longo das etapas. Abaixo é possível observar os dados coletados. 
Figura 28 - Gráfico que apresenta dados coletados no Questionário final

5) De 1 a 10, avalie o quanto você gostou de ter participado desse projeto.

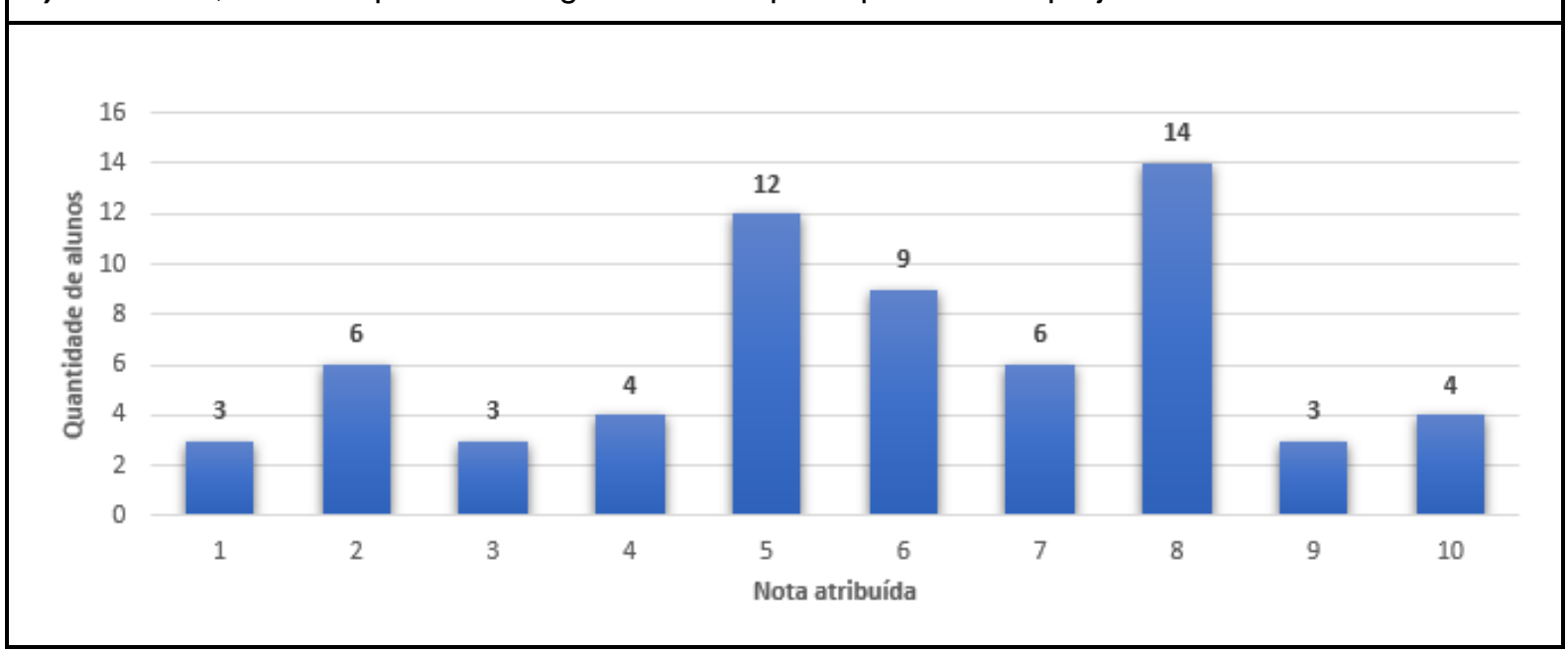

Figura 29 - Gráfico que apresenta dados coletados no Questionário final

6) De 0 a 10, avalie o quanto você evoluiu em relação aos conceitos de probabilidade após as discussões e reflexões do projeto.

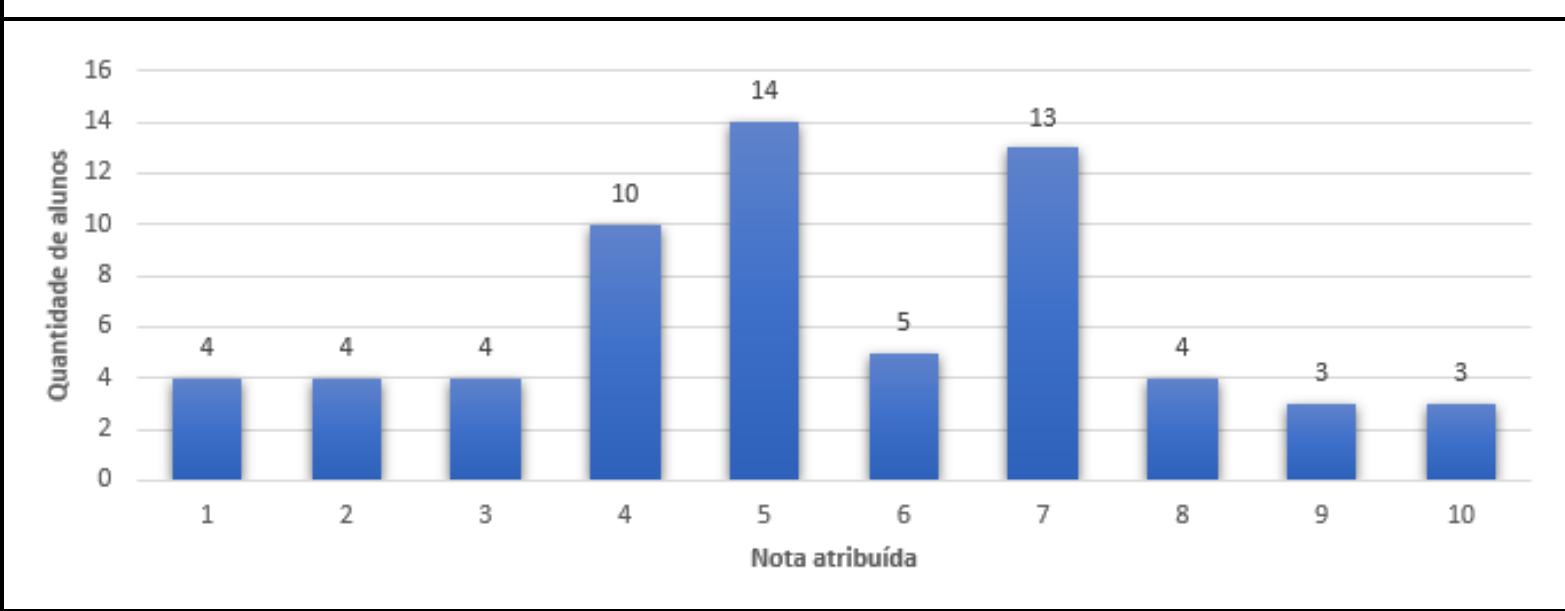

Por fim, ainda havia a proposição de seleção de uma palavra que representasse o percurso pessoal. A nuvem abaixo, foi organizada a partir das palavras levantadas pelos alunos no Questionário final. 
Figura 30 - Nuvem de palavras

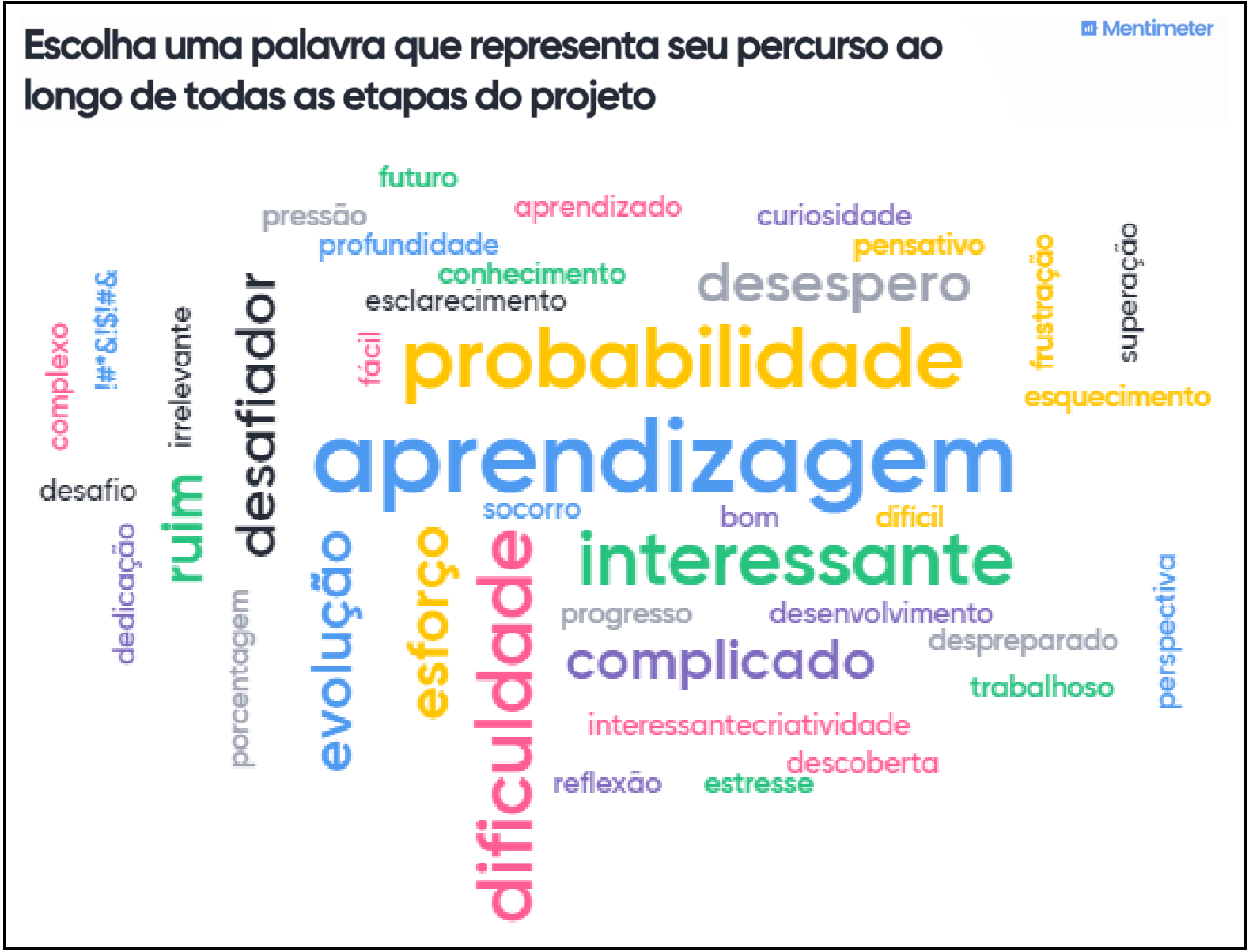

De maneira geral, os dados apresentados nas Figuras 28 e 29 apresentam um resultado equilibrado a respeito da situação investigada. Na primeira é possível perceber que apenas um quarto dos alunos indicou uma nota baixa (menor que 5) para a questão que avalia o nível de satisfação em realizar o projeto. Da mesma maneira, os valores mais altos também não foram muito assinalados pelos estudantes: cerca de apenas $11 \%$ escolheu como resposta os números 9 ou 10. Em relação ao nível considerado de evolução nos conceitos de probabilidade (Figura 29), podemos analisar que os alunos em geral escolheram notas intermediárias. Cerca de $65 \%$ dos estudantes avaliaram com nota intermediária, de 4 a 7 , o quanto evoluiu.

Na nuvem de palavras, no entanto, embora apareçam palavras que poderiam caracterizar alunos que escolheram valores baixos nas Questões 5 e 6 do questionário final, como "dificuldade", "complicado", "desespero" e "ruim", a maioria das palavras com destaque são positivas. Vemos na Figura 30 uma incidência grande de palavras como "aprendizagem", "interessante", "evolução" e "esforço". 


\section{Conclusões e considerações finais}

Com o pressuposto de que a introdução de conceitos relacionados à probabilidade podem se utilizar das novas tecnologias que, a cada dia, aparecem com mais força no cotidiano escolar, cria-se o compromisso de se pensar em uma mudança de perspectiva na forma como o aluno aprende e como esse aprendizado pode ser mais significativo. Visando isso, esteve presente, nesta pesquisa, a hipótese de que os docentes podem se valer de metodologias ativas para conceder lugar de protagonismo ao aluno e, assim, vincular ainda mais os estudantes ao ambiente de sala de aula, estimulando seu envolvimento direto, participativo e reflexivo em todas as etapas do processo, como apontam Bacich e Moran (2018).

Ao elaborar a proposta do projeto oferecendo aos estudantes a experiência de uma criação coletiva de um vídeo digital, pensou-se em promover o protagonismo presente na transformação dos alunos de consumidores em produtores, por meio do processo de produção audiovisual e os elementos que dele derivam, como criatividade, elaboração de texto para roteiro, manuseio das tecnologias, entre outros (LOPES e BIZERRIL, 2018).

Por conta da característica de multimodalidade, ou seja, por compilarem diversos modos de comunicação como oralidade, escrita, imagens dinâmicas, espaços, formas de gestualidade e movimentos (BORBA et al, 2014), a criação de vídeos digitais foi escolhida como alternativa para se trabalhar, ao longo da proposta de aplicação, conceitos relacionados à Probabilidade.

Visando um dos objetivos do ensino de Matemática no ciclo básico, a percepção de que probabilidade é uma medida de incerteza, notou-se na pesquisa que há a necessidade de compreensão, por parte dos alunos, dos conceitos relacionados à aleatoriedade (LOPES, 2008). Construindo conhecimentos nessa direção, os estudantes puderam se favorecer em uma das habilidades propostas na Base Nacional Comum Curricular (BRASIL, 2016), a identificação de prováveis resultados nos acontecimentos do cotidiano, que em grande parte, são de natureza aleatória.

Realizada a aplicação do projeto e posteriormente, a coleta e análise dos dados obtidos, pôde-se ter dimensão de que os pressupostos levantados no início dessa dissertação e retomados na introdução deste capítulo são pertinentes e podem 
ser seguidos como diretrizes na elaboração de sequências didáticas em sala de aula. Após conceber, desenvolver, experimentar e analisar situações de ensino utilizando o recurso da produção audiovisual na introdução do conceito de probabilidade, ficou claro que os estudantes foram favorecidos em diferentes etapas do processo.

A primeira delas é o momento da roteirização em grupo. De maneira geral, as discussões provenientes do período de confecção do roteiro, tanto entre alunos do grupo, como com a mediação da professora ou do pesquisador, fizeram os estudantes revisitar registros e anotações de caderno, refletir sobre a apreensão de conceitos estudados e aprofundar conhecimentos. Tais ações eram fundamentais para decidir os objetos conceituais que seriam expostos em suas produções. Destaca-se como ponto de melhoria do projeto, a proposição de momentos de pesquisa ao longo do período de roteirização em que os estudantes necessitem apresentar suas investigações, seja por escrito ou seja oralmente. Tal indicação baseia-se no fato de alguns grupos de alunos não terem realizado muitas investigações por terem escolhido elaborar seus roteiros visando a exposição superficial do conteúdo.

Ao analisar as primeiras produções dos estudantes, evidenciou-se que o principal momento de construção coletiva de conhecimento foi a discussão após exibição para turma. Assim que os alunos expuseram seus vídeos para os colegas, professora e pesquisador, muitas observações foram levantadas. Os retornos dados pelos seus pares (alunos de outros grupos) e pelos especialistas (professora e pesquisador) caracterizaram-se como direcionamentos importantes para reelaboração de suas produções. Foi possível perceber também que o momento de autoavaliação frente à turma fez com que os grupos pudessem elencar diversos aspectos de melhoria. De maneira geral, essa etapa foi classificada como uma verdadeira parada para reflexão.

Examinando os vídeos produzidos, pôde-se concluir que o recurso didático escolhido favoreceu as diferentes abordagens e significados de probabilidade. Alguns grupos decidiram por confrontar aspectos intuitivos com definições clássicas de atribuição de probabilidade, como no caso dos grupos que optaram por abordar como tema o Paradoxo de Monty Hall. Outros grupos de estudantes, direcionaram suas produções para contrapor elementos subjetivos de probabilidade, como superstições a cálculo de possibilidades laplacianos tradicionais. Por fim, em alguns vídeos foi possível observar aspectos típicos da concepção de probabilidade a posteriori 
baseada em análises estatísticas, abordando dessa maneira a probabilidade de forma frequentista.

Retomando a questão norteadora da pesquisa, apresentada no Capítulo 1, ao fim de toda a investigação é possível afirmar que foram diversas as contribuições observadas do processo de criação de vídeos digitais no ensino-aprendizagem de Probabilidade. Uma das principais contribuições identificadas certamente foi a mudança dos moldes oferecidos aos estudantes no desenvolvimento de conceitos matemáticos. Ao se transpor o aluno de um cenário tradicional para um projeto em grupo de construção audiovisual há muito ganho. O cenário inicial caracteriza-se por um estudo que se centraliza em um processo em que o professor centraliza a exposição inicial, o estudante desenvolve a temática em exercícios de caráter determinísticos buscando respostas numéricas exatas. O projeto proposto, por sua vez, proporciona aos estudantes mais interações com os integrantes de seu grupo, os demais colegas da sala e a relação com o conhecimento torna-se mais autônoma e ganha encaminhamentos e desdobramentos que variam de acordo com suas preferências e interesses. Tais relações apenas são potencializadas em situações de aprendizagem na qual o aluno está em papel de protagonista.

Além disso, ao se utilizar uma plataforma diferente de um ambiente tradicional de lápis, borracha e papel, os estudantes conseguem transpor situações de estudo centralizadas em resolução de exercícios e comparação com gabarito. Há muito mais liberdade para abordar os objetos matemáticos de múltiplos modos, potencializando assim a compreensão de conteúdos estatísticos na qual o aluno precisa analisar seus diferentes significados, como é o caso da probabilidade.

Ficam, por fim, algumas sugestões de melhorias e adaptações para a proposta apresentada que só puderam ser identificadas após a análise dos dados obtidos. Tanto na primeira experiência como no próprio projeto aplicado, o contexto social dos sujeitos envolvidos foi similar. Em ambas as situações, o ambiente escolar era caracterizado por um colégio particular, localizado em região nobre da cidade de São Paulo, com um número aproximado de 25 alunos por turma. Deste modo, acredita-se que se consolida como um dos próximos interesses da pesquisa nesse tema, a investigação de resultados a partir de aplicação de projeto similar em escolas em contexto social distinto. Labruine e Ferreira (2018), apontam que há atualmente grande acesso a tecnologias digitais e que os smartphones e computadores estão cada vez mais presentes em diferentes níveis sociais. Assim, segundo os autores, 
"graças, em parte, ao barateamento dos artefatos digitais, tem sido democratizada a produção de registros multimodais" e assim, mesmo em escolas públicas, torna-se possível a aplicação de propostas de criação de vídeos em sala de aula como recurso pedagógico (p. 418).

Outro eventual desdobramento da presente pesquisa é a perspectiva de elaboração de projetos que utilizem o vídeo como recurso pedagógico para favorecer a interdisciplinaridade. Pensando em elementos que foram observados na roteirização e aspectos de linguagem apresentados nas produções dos alunos investigados vislumbrou-se grande oportunidade para relacionar conceitos estudados na disciplina de Língua Portuguesa, por exemplo. Há a possibilidade de aproximação também às áreas de artes, como artes visuais e artes cênicas. Além disso, analisando a diversidade das criações dos estudantes, aponta-se para uma direção na qual a produção de vídeos digitais em sala de aula pode-se aproximar de todo e qualquer conteúdo desenvolvido nas diferentes disciplinas. 


\section{Referências bibliográficas}

ALMEIDA, D. S.; AZEVEDO, E. B. V.; CARVALHO, L. A.; NOGUEIRA, L. A. O vídeo na construção de uma educação do olhar. PerspectivasOnLine 2007-2011, v. 3, n. 9, 2014.

BACICH, L.; MORAN, J. M. Metodologias ativas para uma educação inovadora: Uma abordagem teórico-prática. Porto Alegre: Penso. 2018.

BARBERINO, M. R. B. Ensino de Estatística através de Projetos. Dissertação de Mestrado Profissional em Ensino de Matemática. Instituto de Matemática e Estatística, Universidade de São Paulo, São Paulo, 2016.

BATANERO, C.; GODINO, J. D.; VALLECILLOS, A.; GREEN, D. E.; HOLMES, P. Errors and difficulties in understanding elementary statistical concepts. International Journal of Mathematical Education in Science and Technology, v. 25, n. 4, p. 527-547, 1994.

BATANERO, C.; GODINO, J. Análisis de datos y su didáctica. Departamento de Didáctica de la Matemática de la Universidad de Granada, 2001.

BATANERO, C. Significados de la probabilidad en la educación secundaria. Revista Latinoamericana de Investigación en Matemática Educativa, RELIME, p. 247-263, 2005.

BORBA, M. C.; ARAúJO, J. L. Pesquisa qualitativa em educação matemática, v. 9, Autêntica Editora. 2004.

BORBA, M. C.; SCUCUGLIA, R. R. S.; GADANIDIS, G. Fases das Tecnologias Digitais em Educação Matemática: sala de aula e internet em movimento. Belo Horizonte: Autêntica, 2014.

BRASIL. Ministério da Educação. Parâmetros Curriculares Nacionais: Matemática. Secretaria de Educação Fundamental. Brasília, MEC/SEF. 1997.

BRASIL, Diretrizes Curriculares Nacionais Gerais da Educação Básica. Ministério da Educação, Secretaria de Educação Básica, Diretoria de Currículos e Educação Integral. Brasília: MEC, SEB/DCEI, 542p. 2013.

BRASIL. Ministério da Educação. Secretaria da Educação Básica. Base nacional comum curricular. Brasília, DF, 2016. Disponível em:

<http://basenacionalcomum.mec.gov.br/\#/site/inicio>. Acesso em: set. 2016.

COUTINHO, C. Q. S; SANTOS, A. A.; GIORDANO, C. C. Educação Estatística, cidadania e livros didáticos: o papel do letramento estatístico. Revemat: Revista Eletrônica de Educação Matemática, 14(1), 1-15. 2019. 
DOMINGUES, N. S. O papel do vídeo nas aulas multimodais de Matemática Aplicada: uma análise do ponto de vista dos alunos. 2014. Dissertação (Mestrado em Educação Matemática) - UNESP, Rio Claro, 2014.

DOMINGUES, N. S.; BORBA, M. DE C. Compreendendo o I Festival de Vídeos Digitais e Educação Matemática. Revista de Educação Matemática, São Paulo, REMat, v.15, n.18, p.47-68, jan/abr. 2018.

FERRÉS, J. Como integrar el video en la escuela. Barcelona: Ediciones CEAC, S.A. 1988.

FERRÉS, J. Vídeo e educação. (2ª ed.). Porto Alegre: Artes Médicas. 1996.

FRANCO, S; AMELIA, M. Pedagogia da pesquisa-ação. Educação e pesquisa, v. 31, n. 3, 2005.

FREIRE, P. Pedagogia da autonomia: saberes necessários à prática docente. São Paulo: Paz e Terra, 1996.

GARNICA, A. V. M. História Oral e Educação Matemática. In: BORBA, M.C.; ARAÚJO, J.L. (orgs.). Pesquisa Qualitativa em Educação Matemática. Belo Horizonte: Autêntica. 2004. (Coleção Tendência em Educação Matemática).

GOLDENBERG, M. A arte de pesquisar: Como fazer pesquisa qualitativa em Ciências Sociais. ( $8^{\underline{a}}$ ed.). Rio de Janeiro: Record. 2004.

IMENES, L. M.; LELLIS, M. Matemática: Imenes \& Lellis. São Paulo, SP, $1^{a}$ edição. 2010.

LISBOA, E. S.; JUNIOR, J. B. B.; COUTINHO, C. P. O contributo do vídeo na educação online. In: Congresso internacional galego-português de psicopedagogia, X., 2009, Braga. Actas... Braga: Universidade do Minho, 2009.

LOPES, C. A. E. O ensino da estatística e da probabilidade na educação básica e a formação dos professores. Cad. Cedes, Campinas, v. 28, n. 74, p. 57-73, 2008.

MAGALHÃES, M. N. Probabilidade e variáveis aleatórias. Edusp, 2006.

MAGALHÃES, M. N.; LIMA, A. C. P. Noções de probabilidade e estatística. - $7^{a}$ ed São Paulo: Editora da Universidade de São Paulo. 2013.

MORAN, J. M. Leituras dos meios de comunicação. São Paulo: Pancast. 1993.

MORAN, J. M. O Vídeo na Sala de Aula. Comunicação e Educação, v. 2, p. 27-35, 1995.

MORAN, J. M. Desafios da televisão e do vídeo à escola. Integração das Tecnologias na Educação, p. 96-100, 2005. 
MORAN, J. M. Metodologias ativas para uma aprendizagem mais profunda. Metodologias ativas para uma educação inovadora: uma abordagem teórico-prática. Porto Alegre: Penso, p. 02-25, 2018.

PONS, J. P. Visões e conceitos sobre a tecnologia educacional. In: SANCHO, J.M. (Org.). Para uma tecnologia educacional. Porto Alegre: Artes Médicas. cap.2, p. 5071, 1998.

SANTOS, M. L. Do giz à Era Digital. São Paulo: Zouk, 2003.

SILVA, I. A. Probabilidades: a visão laplaciana e a visão frequentista na introdução do conceito. Dissertação de Mestrado, Pontifícia Universidade Católica de São Paulo, São Paulo, 2002.

STEFFE, L; THOMPSON, P. Teaching experiment methodology: Underlying principles and essential elements. In R. Lesh \& A. E. Kelly (Eds.), Research design in mathematics and science education. Hillsdale, NJ: Erlbaum, p. 267-307, 2000.

OECHSLER, V. Vídeos e Educação Matemática: um olhar para dissertações e teses. In: Encontro Brasileiro de Estudantes de Pós-Graduação em Educação Matemática, XIX, 2015, Juiz de Fora - Minas Gerais. Anais... Juiz de Fora - Minas Gerais: UFJF, p. 1-12, 2015.

OECHSLER, V.; FONTES, B. C.; BORBA, M. C. Etapas da produção de vídeos por alunos da educação básica: uma experiência na aula de Matemática. Revista Brasileira de Educação Básica, v. 1, p. 71-80, 2017.

OLIVEIRA, C. R.; CORDANI, L. K. Julgando sob incerteza: heurísticas e vieses e o ensino de probabilidade e estatística. Educação Matemática Pesquisa, v. 18, n. 3, 2016.

OLLAIK, L. G.; ZILLER, H. M. Concepções de validade em pesquisas qualitativas. Educação e Pesquisa, São Paulo, v. 38, n.1, p. 229- 241, 2012.

VARGAS, A.; ROCHA, H. V.; FREIRE, F. M. P. Promídia: produção de vídeos digitais no contexto educacional. RENOTE, v. 5, n. 2, 2007.

WILD, C. J.; SEBER, G. A. F. Encontros com o acaso: um primeiro curso de análise de dados e inferência. Tradução Cristiana Filizola Carneiro Pessoa. Rio de Janeiro: LTC Editora, 2004. 


\section{Apêndices}

\subsection{Aspectos técnicos referentes ao programa de edição OpenShot}

O programa, disponibilizado de forma gratuita no endereço eletrônico https://www.openshot.org/pt/download (acesso em: agosto 2019) para uso em sistema Windows, Linux e Mac Osx, apresenta a interface abaixo:

Figura 31 - Captura da tela principal do programa de edição OpenShot

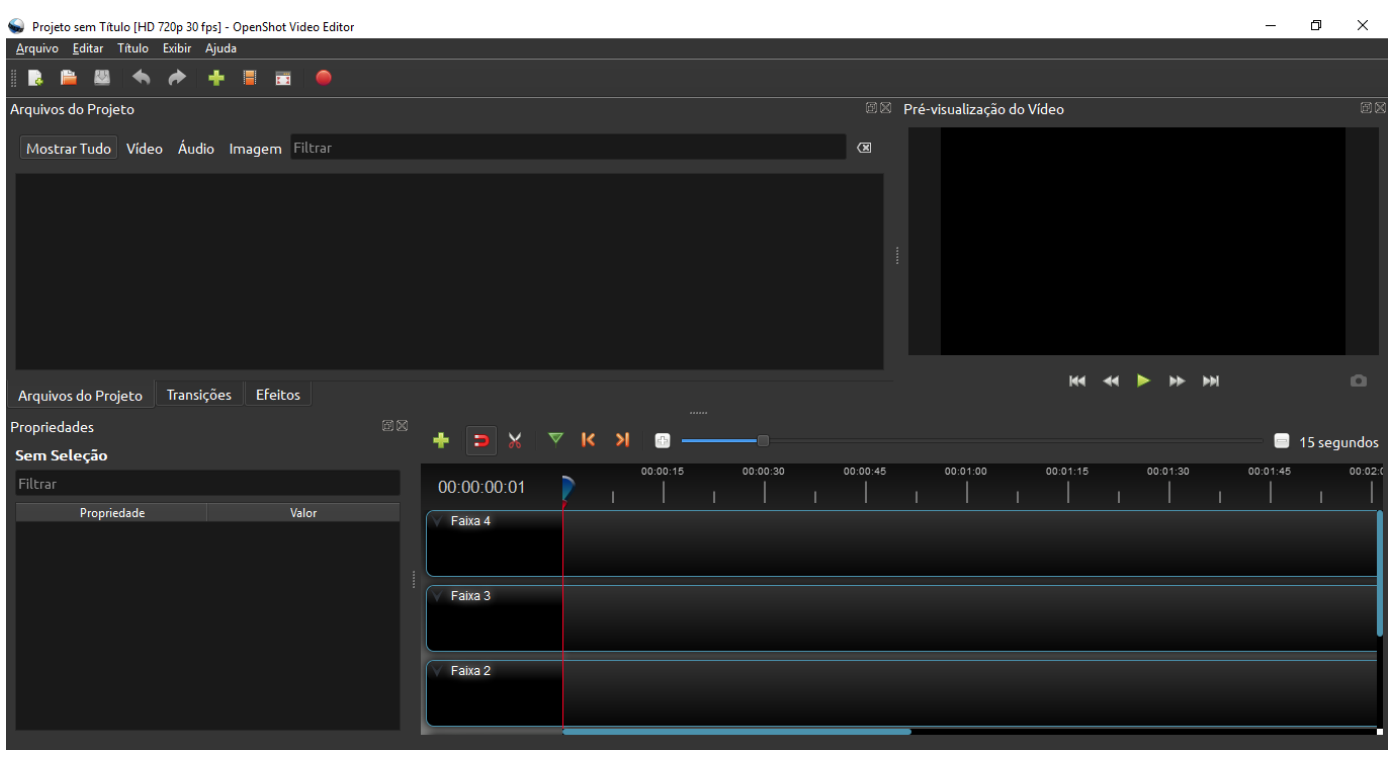

Assim como a maioria dos editores de vídeo, pode-se subdividir a interface do OpenShot em quatro regiões. No canto superior esquerdo há um setor para a importação de vídeos brutos - ainda não editados - áudios e imagens. Nesta região, o editor permite que o usuário importe arquivos clicando na cruz verde do menu superior ou arrastando-os e soltando-os em sua área de trabalho. Há também um menu inferior que contém algumas opções de transições para serem utilizadas entre uma tomada e outra e efeitos para incrementar as edições.

Ao lado desse setor, há uma região na qual pode-se realizar pré-visualizações do vídeo que se está editando. Após qualquer alteração na edição, pode-se acionar o play e testar a adequação das alterações. No canto inferior esquerdo pode-se analisar e editar as propriedades técnicas e, ao seu lado, há a linha do tempo. 
Conforme mencionado anteriormente, é nesse setor que o aluno pode se aprofundar e realizar ajustes de maneira mais profissional nos objetos presentes em sua edição.

É nesse último setor que o usuário pode ordenar, cortar e editar suas tomadas de gravações, arrastando os vídeos do canto superior esquerdo e soltando-os em sua área de trabalho. Seus trechos de gravações aparecerão na linha do tempo como retângulos com largura correspondente ao seu tempo de duração e, utilizando a ferramenta de corte, representada por uma tesoura no menu superior desta seção, é possível dividir a sua tomada em duas ou mais partes e, caso seja do interesse do usuário, eliminar alguma dessas subdivisões.

É também na linha do tempo que os áudios, imagens e textos podem ser incluídos no vídeo a ser editado. Através de um sistema similar ao descrito acima, de inclusão de tomadas de vídeo pelo arrastar e soltar, o usuário pode sobrepor alguma trilha sonora de fundo, ou ainda explicações adicionais, textos complementares, imagens elucidativas, entre outros. 